Portland State University

PDXScholar

\title{
A Descriptive Study of the Oregon Mentorship Program
}

Gaynelle Louise Nolf

Portland State University

Follow this and additional works at: https://pdxscholar.library.pdx.edu/open_access_etds Let us know how access to this document benefits you.

\section{Recommended Citation}

Nolf, Gaynelle Louise, "A Descriptive Study of the Oregon Mentorship Program" (1991). Dissertations and Theses. Paper 1198.

https://doi.org/10.15760/etd.1197

This Dissertation is brought to you for free and open access. It has been accepted for inclusion in Dissertations and Theses by an authorized administrator of PDXScholar. Please contact us if we can make this document more accessible: pdxscholar@pdx.edu. 


\title{
A DESCRIPTIVE STUDY OF THE OREGON \\ MENTORSHIP PROGRAM
}

by

GAYNELLE LOUISE NOLF

A dissertation submitted in partial fulfillment of the requirement for the degree of

\author{
DOCTOR OF EDUCATION \\ in \\ EDUCATIONAL LEADERSHIP
}

Portland State University

- 1991 
TO THE OFFICE OF GRADUATE STUDIES:

The members of the committee approve the dissertation of Gaynelle Louise Nolf presented June 24, 1991.

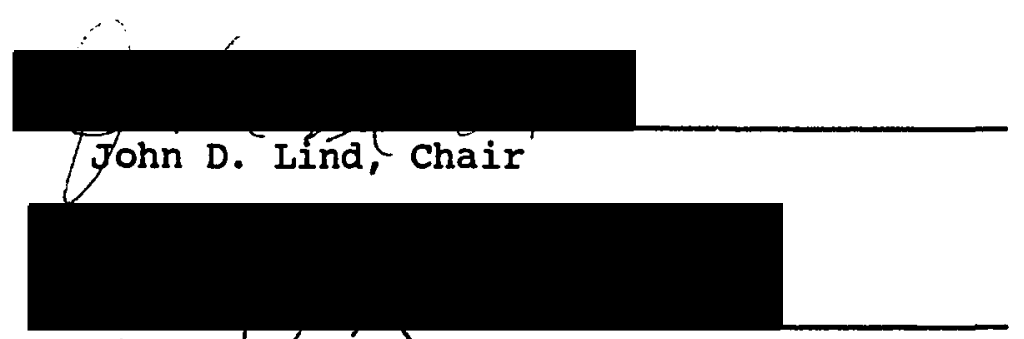

Alan J.l Rousseau
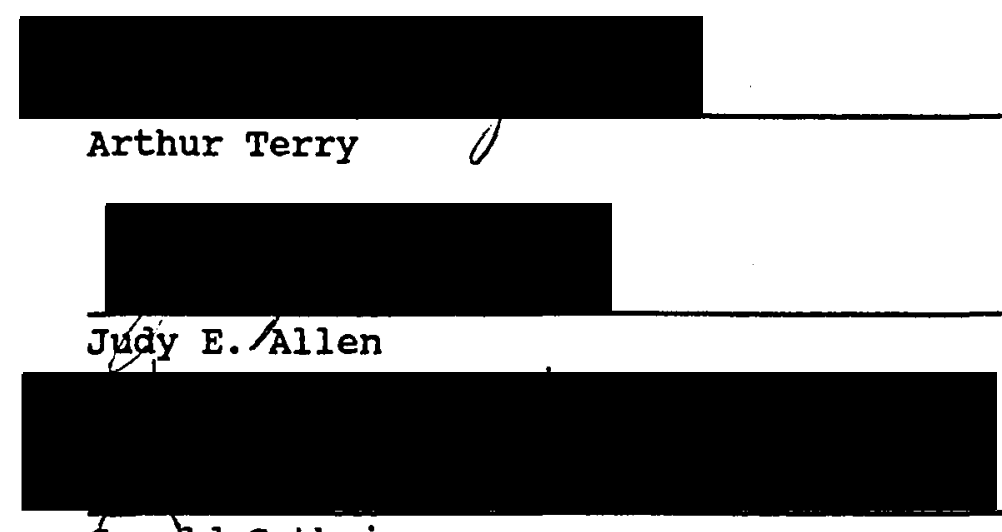

Gerald Guthrie

APPROVED :

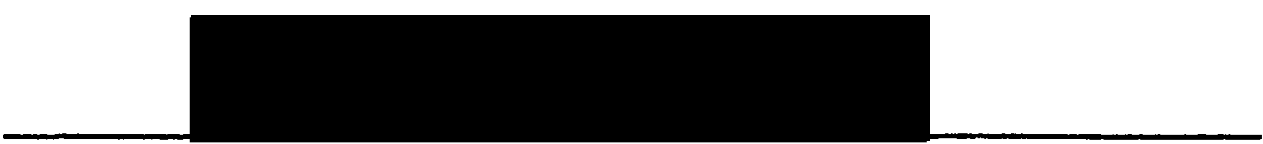

Robert Everhart, Dean, School of Education

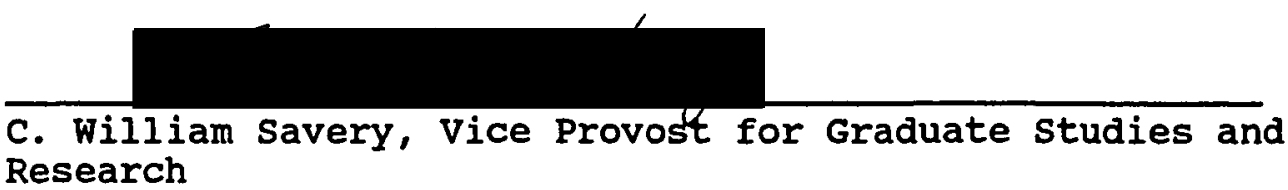


AN ABSTRACT OF THE DISSERTATION OF Gaynelle Louise Nolf for the Doctor of Education in Educational Leadership presented June $24,1991$.

Title: A Descriptive Study of the Oregon Mentorship Program APPROVED BY THE MEMBERS OF THE DISSERTATION COMMITTEE:

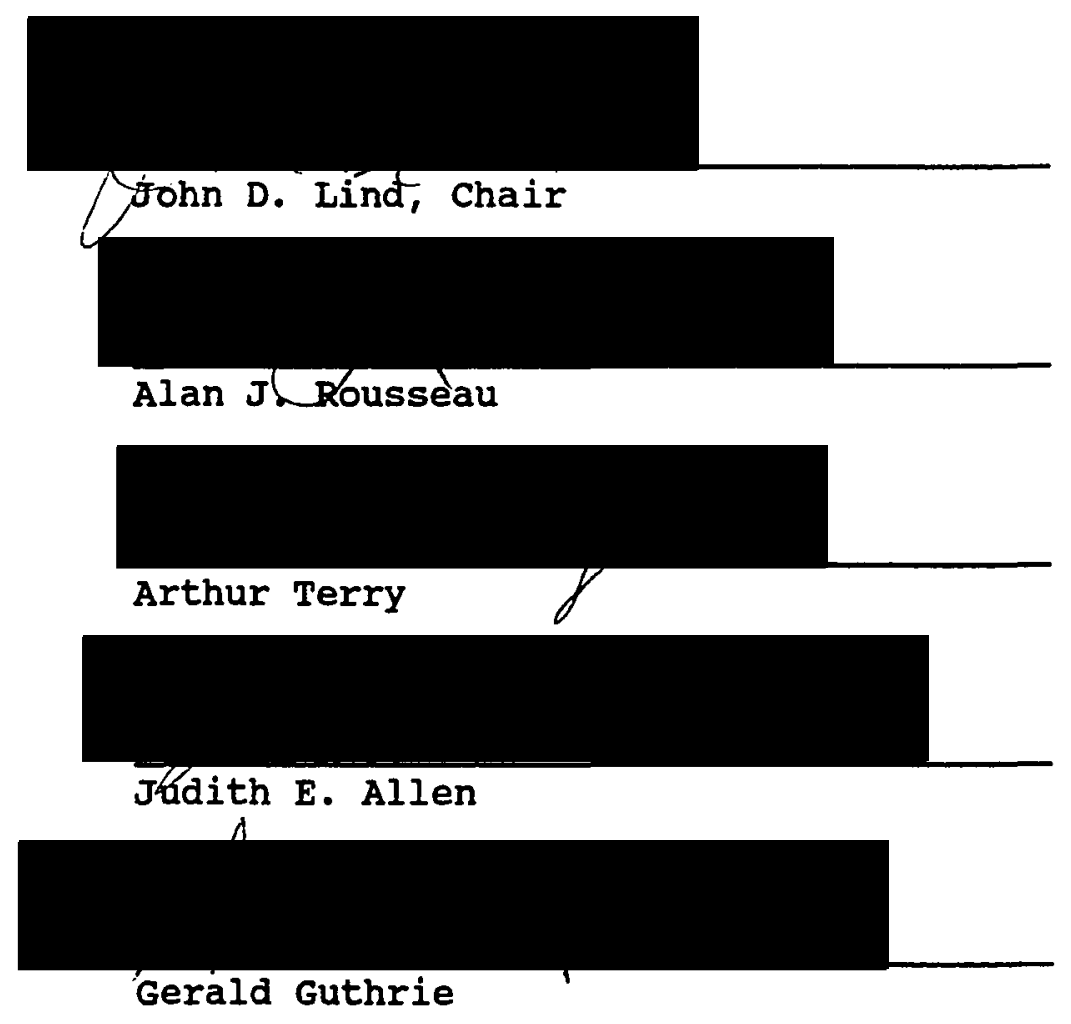

The purpose of this study was to provide a comprehensive and descriptive study of the Oregon Mentorship Program. The study examined literature on adult mentorship programs particularly related to education and educational 
administration, and gathered mentor and protege perceptions on the personal and professional usefulness of program activities and characteristics. The analysis of the data may provide guidance for future formal mentorship programs designed to prepare better beginning administrators in the field of education.

Data were gathered utilizing a questionnaire. All participants in the program (77 mentors and 79 proteges) were surveyed with an instrument designed around the followup study model. Statistical analyses of the data was based upon 55 mentor and 57 protege respondents. Chi square, mean, t-test, and Kendall's coefficient of concordance were used to determine significant differences among mentors and proteges. Two qualitative methodologies of analysis, phenomenology and development of a category system for analysis which seeks convergence and divergence were also applied to the responses.

Major findings of this study were grouped as perceptions, structure, logistics, participant relationships, and demographic. Mentors and proteges had few differences in the way they perceived the mentorship program. Mentors and proteges did not agree on the significance of same/different gender mentor/protege pairings. Age differential between mentors and proteges was also not found to be a significant factor. 
Structurally, proteges more than mentors felt that directives and guidelines were unsatisfactory. Proteges did not agree that satisfactory year-long goals were established. Logistically, proteges were more likely to come to mentors than mentors to proteges. No significant differences existed in any of the items concerning the participant relationship category; mentors and proteges responded in similar ways to each of the questions. The study recommended future actions to enhance the Oregon Mentorship Program and made recommendations for further research into formal mentorship programs. 


\section{ACKNOWLEDGEMENTS}

I am indebted to and wish to gratefully acknowledge the many people who have contributed to the successful completion of the dissertation.

I am especially appreciative of the time taken by the mentors and proteges of the Oregon Mentorship Program for participating in this study. Their insights and perspectives were invaluable to me in examining the mentorship program. I also wish to thank the confederation of Oregon School Administrators, specifically the Director of the Mentorship Program, Dr. Christine Tell, for her assistance and support.

My committee members each made contributions for which I am indeed indebted. Dr. Jack Lind, who chaired the committee, provided valuable feedback and constant support. Dr. Art Terry supplied me with numerous suggestions which improved this work. Dr. Jerry Guthrie was a source of consistent encouragement and provided detailed support concerning processes. Dr. Al Rousseau provided support, consistent feedback, reassurance, and friendship. I also an particularly appreciative of Dr. Judith Allen's willingness to step in and provide feedback midway through the writing of this dissertation. 
I am grateful to the Beaverton School District, its Board, and its Superintendent, Dr. Jim Hager, for providing eight weeks of leave time to complete the data analysis and final writing of this dissertation. In addition, I wish to thank Dr. Mary Callan, Assistant Superintendent, for her encouragement, sense of humor, friendship, and constant reminder to keep writing. A special thanks to my colleagues, the Sunset High school administrative team, for their support during the last year.

Many other people provided support and encouragement at various stages of my doctoral work and the writing of this dissertation. A very special thank you to my doctoral colleague and friend, Dr. Virginia Homeier Anderson, who has been a constant source of strength, support, and editing expertise and who set the pace. I am grateful to my mentors. To Dr. Bob Kremer, my first professional mentor as a beginning school administrator, I am greatly appreciative; to Dr. Al Davidian, both a formal and informal mentor, for his insight, encouragement, guidance, interest, inspiration, and undaunted sense of humor, I am indebted; to Dr. Pat Schmuck, an informal mentor, I extend thanks for her continued guidance. I am also appreciative of the neverending support of my protege, Pia Ekelof, for her spirit and confidence that I could succeed at this project. To Mary Helen Simonson for her editorial expertise, technical assistance, and long hours at the keyboard, a very special 
thanks; without her, this task would not have made the deadline. I am appreciative of my friend and neighbor, Laura Lilly, for her willingness to proofread at any hour of the day or night and to believe that my completion date was realistic. A special thanks to Pati sluys of Portland state University for her proofreading and formatting suggestions.

I am especially grateful to my husband, Severn $w$. "Sandy" Koski, for his patience, support, and encouragement while I accomplished this task. To my mother, Louisa "Toni" Nolf, I am forever grateful for providing essential sunshine, inspiration, and a will to continually pursue higher educational goals.

I truly could not have accomplished a task of this immensity without wonderful support from my colleagues, friends, and family. My sincere thanks to all who have helped and guided me in this process. Indeed, the task is complete. 
TABLE OF CONTENTS

PAGE

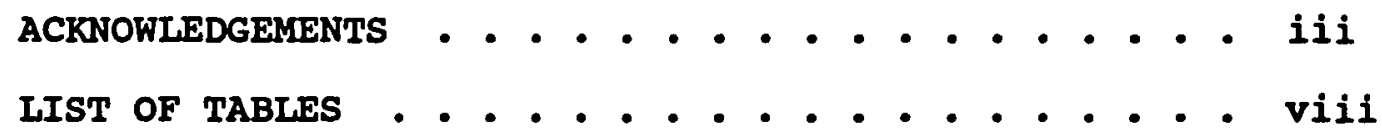

CHAPTER

I STATEMENT OF THE PROBLEM . . . . . . . 1

Background . . . . . . . . . . . 2

Rationale . . . . . . . . . 8

Limitations . . . . . . . . . . 11

Definition of Terms . . . . . . . . 13

Purpose of the study . . . . . . . . 16

II REVIEW OF THE LITERATURE . . . . . . . 18

The Concept of Mentoring . . . . . . 20

Mentor and Protege Relationships . . . . 32

The Impact of Mentoring within the Teacher Induction Process .......... 44

Mentors and Mentorship Programs in

Educational Administration ... . . 49

Summary . . . . . . . . . . . . 54

III METHODS . . . . . . . . . . . 57

General Plan of study . . . . . . . . 57

subjects . . . . . . . . . . . 59

Instrument ... . . . . . . . . 65

Procedures . . . . . . . . . . 69 
Data Analysis Procedures . . . . . . 71

IV RESULTS . . . . . . . . . . . 76

Perceptions . . . . . . . . . . 77

structure ............... 87

Logistics . . . . . . . . . . . . 91

Participant Relationships . . . . . . 93

Demographics . . . . . . . . . . . 94

V SUMMARY AND RECOMMENDATIONS . . . . . . 110

Introduction . . . . . . . . . . 110

Summary and Conclusions . . . . . . 111

Implications for Practice . . . . . . 117

Recommendations for Research . . . . . 122

REFERENCES ................ 126

APPENDICES

A SURVEY INSTRUMENT--QUESTIONNAIRE . . . . . 141

B WRITTEN RESPONSES FROM QUESTIONNAIRE:

MENTORS . . . . . . . . . . . 159

C WRITTEN RESPONSES FROM QUESTIONNAIRE:

PROTEGES . . . . . . . . . . . . 181

D ADDITIONAL COMMENTS FROM QUESTIONNAIRE: MENTORS . . . . . . . . . . . 202

E ADDITIONAL COMMENTS FROM QUESTIONNAIRE:

PROTEGES . . . . . . . . . . . 206 


\section{LIST OF TABLES}

TABLE

PAGE

I

II

III

IV

V

VI

VII

VIII

IX

$\mathrm{X}$

XI

XII

XIII

XIV

XV

XVI
Gender of Mentorship Participants . .

61

Gender of Oregon Administrators 1989-90

School Year . . . . . . . .

Geography of Participating Mentors . . 63

Geography of Participating Proteges .

63

Rank Ordering of Mentor Expectations for Program Year . . . . . . .

Rank ordering of Mentor outcomes for program Year ......... . 80

Rank Ordering of Protege Expectations for Program Year . . . . . . .

Rank Ordering of Protege Outcomes for Program Year . . . . . . .

Rank Ordering of Attributes for Successful Mentorship Programs ... . . .

Rank Ordering of Activities by Perception of Value to Oregon Mentorship Program 86

Statistical Analysis of Survey Question $9 \quad 88$

Statistical Analysis of Survey Question $12 \quad 89$

Statistical Analysis of Survey Question 2391

Statistical Analysis of Survey Question $10 \quad 93$

Professional status of Proteges During Mentorship and at Time of Response to Survey . . . . . . . . .

Mean Years Experience as an Educator and Mean Number of Years in current Position 
XVII

Highest Degree Attained by Survey Respondents .......... . 97

XVIII Age of Respondents . . . . . . . 97

XIX Ethnicity of Respondents . . . . . 98 
CHAPTER I

STATEMENT OF THE PROBLEM

During the last two decades, educators have been dedicated to making schools more effective. The effective schooling research base has identified schooling practices and characteristics including strong instructional leadership that make a difference in teaching and learning. This study focused on an element of the school improvement process, that of providing mentoring opportunities for aspiring or beginning school administrators. In particular, this study focused on the Oregon Mentorship Program which was initiated in 1986.

Each year since the fall of 1986,20 proteges, who were aspiring or beginning administrators, were selected to be mentored by 20 administrators who were considered by the sponsoring organizations to be exemplary administrative "masters" in the field. Although the Oregon Mentorship Program has continued much as it was started, there has been limited data collection on the perceived usefulness of the activities and program characteristics for the aspiring or beginning administrator. Little data have been collected concerning the activities and characteristics of the program that were perceived as useful or successful by the 
administrators serving as mentors. It was the researcher's intention to examine the literature on adult mentorship programs, particularly related to education and educational administration. It was also the intention of the researcher to gather mentor and protege perceptions on the personal and professional usefulness of program activities and characteristics and to provide a comprehensive and descriptive study of the Oregon Mentorship Program which may provide guidance for formal educational administration programs striving to prepare better beginning administrators.

\section{BACKGROUND}

American public schools have been a testimony to this society's dedication to the ideal of education as a right of all young people. The founders of public education were concerned with establishing basic literacy for all in terms of rudimentary skills in reading, mathematics, and writing. Education met the needs of an agrarian nation because the necessary skills were not sophisticated ones at that time. Society has changed. Society has become increasingly complex as it has moved from a rural orientation through industrialization to our current information society. In Megatrends, Naisbitt (1982) wrote of both a different nation and a different society. Our global society is evolving 
toward a cooperative rather than competitive society where education for the realities of the society is appropriate.

Flesch's (1955) Why Johnny Can't Read began a decade in which examination of the public school grew increasingly critical. Following the turbulence of the 1960s, the 1970s saw introspection on the quality of the American public school. Following the coleman (1981) report on the state of the nation's large urban schools, the excellence in education movement began to gather momentum and has continued to be the impetus for successful school theory. As the debate over schools continued, Edmonds' (1979a, 1979b, 1982) writings on effective schools and programs of school improvement and the National Commission on Excellence in Education's (1983) Nation At Risk crystallized the issue for many concerning what was perceived as mediocrity in public school education. Nation At Risk was soon followed by the Carnegie Forum's (1986) A Nation Prepared: Teachers for the 21st Century that lent even more credence to the popular belief that the nation's schools were facing difficult times. Concern about educators, including their high school education, their preservice training, their student teaching experience, and the quality of their post secondary institutions, all came under examination. As a consequence of three decades of criticism, American educators have continued to examine the factors that may improve, refine, or to prepare better the products 
of our nation's school districts, and those colleges and universities that prepare teachers and administrators for service in those districts. This study focused on one aspect of the general improvement effort in the area of staff development, that of "mentoring." Since the day when in Homer's (cited in Hamilton, 1942) The Odyssey, Ulysses entrusted his son Telemachus, to his trusted friend, Mentor, the idea of guiding the novice by those with greater experience has been in practice.

Traditionally, university educational administration programs concentrate on theory and have been able to provide only limited opportunities for extensive field experiences, internships, or mentorships. In professions such as business, medicine, and some trades, extensive apprenticeships or mentorships, sometimes lasting a year or longer, have been accepted methods of learning a new role or job. In 1987, the National Commission on Excellence in Educational Administration (cited in Forsyth, 1987) spoke in favor of redefinition of educational leadership and made the recommendation that preparation programs provide an intellectual background in education and organizational life while guiding administrative candidates through mentored practice. Mentoring in school settings has been emerging as an important issue in contemporary American education. Educational literature has been replete with references to the value of mentorships to create a 
successful transition into administrative roles. Many educational leaders recognize the value of mentorships in furthering the development of future principals' knowledge, positive leadership qualities, communication skills, clarity of vision, problem-solving skills, and sensitive and caring attitudes through collaboration with practicing school administrators. In addition, recent educational reform movements have placed significant emphasis on the influence that school administrators, particularly principals, have on improving schools. This influence has resulted in greater attention being placed on preparation and recruitment of administrative aspirants.

In some cases, states have enacted policies; Maine has made mentoring a requirement for certification and/or certification renewal; ohio has enacted a policy requiring all school districts to plan and implement programs that provide support to newly employed professional educators. The Danforth Foundation initially, and later the ohio Leadership in Educational Administration Development (IEAD) Center, piloted administrative mentorship programs. Throughout those piloted projects, mentoring was viewed as an important form of ongoing professional development that benefits both the mentor and the person being mentored (Daresh \& Playko, 1989a).

Making use of mentoring relationships as a way of enhancing the professional preparation of educational 
administrators has become more widespread. In 1986, after the Department of Education made available approximately seven million dollars in funding to assist individual states in developing programs designed to promote programs and activities that would be useful to practicing and aspiring school administrators, LEAD Centers were created. No nationwide model was prescribed; the Centers were to represent efforts to bring together practitioners of school administration, state education agencies, and colleges and universities in developing activities designed to enhance preservice and inservice learning for school leaders.

Current literature has placed emphasis on the ways in which the mentor supports and guides the protege. However, the relationship might also be described as mutually enhancing (Kram, 1985b); improved job satisfaction, increased peer recognition, and potential career advancement (Gray, 1986) may be benefits derived by those who serve as mentors. According to Pence (1989a),

Practicing school administrators frequently feel isolated and seldom have anyone [sic] with whom to discuss ideas. Mentors report one way that professional growth occurs for them is through articulating rationale for their decisions with proteges. Mentors also receive satisfaction by sharing their experiences and knowledge with proteges and by helping proteges achieve success. (p. 166)

The mentoring relationship has been reported to increase a protege's self-confidence as he/she moves into the first year of administration (Pence, 1989a). It is believed by a number of researchers that there are three 
equal parts in the development of new administrators: academic preparation for theory, field-based learning for acquisition of skills while on site in a school, and professional formation where mentoring is an essential part (Daresh \& Playko, 1989d).

As a collaborative project, the confederation of Oregon School Administrators (COSA) teamed with the Oregon Department of Education (ODE), Northwest Women in Educational Administration (NWEA), and the Northwest Regional Educational Laboratory (NWREL) to design, structure, and implement a state-wide mentorship program. The program has been a jointly-funded project by the founding organizations and agencies with additional funds supplied by Leadership in Educational Administration Development (IEAD) grant monies. In Oregon, cosA oversees the grant monies and, therefore, has been able to direct the IEAD Center and support the Oregon Mentorship Program. The Mentorship Program design initially had many aims but the central theme was that of professionally assisting other professionals in a series of planned and unplanned experiences to prepare them better for positions as school and district-level administrators. Implicit in the purpose was the aim to expose aspirants to the realities of these kinds of positions and permit aspirants to develop their skills, learn the culture of administration, focus their 
continued formal educational needs, and gain a more realistic picture of the role of the school administrator.

\section{RATIONALE}

Public education has been under close public scrutiny. Many of the problems facing Americans, such as, unemployment, unskilled workers, societal fragmentation, increases in crime, and teenage parenthood, have been blamed on the public education system. The Chicago plan, where the community selects the staff and administration, is an example of a reaction to what has been perceived as a betrayal of the trust placed in schools. To infer causality between the education of American students and the problems noted above would be tenuous; the problems facing the nation are no doubt multifocal, and many of them are beyond the scope of either schools or society upon which to act. However, as responsible professionals, educators must listen to the concerns and complaints, and take action when appropriate. One particular complaint, the competence of educators, whether they are classified support staff, certified faculty, or administrators, can be addressed. As educators, we are public employees; as educators, we are not above reproach. As a consequence, we must consider means to validate the competence of those involved in educating America's youth. 
One means of keeping the faith with the public that supports education is to be certain that in either preservice or continued education of educators, the issues of basic competence and fitness to hold positions of responsibility are paramount. We consider it reasonable to make cartain that our physicians are properly schooled, tested for competence, and appropriately credentialed, and that only those who pass the bar exam are licensed to practice law; we require electricians, plumbers, and mechanics to have met the standards for admission to journeyman status. However, we do not hold these same expectations for our educators. Possession of a teaching certificate presumes competence to teach; in practice, this translates into being able to demonstrate successful completion of prescribed courses of study. With the exception of limited practica opportunities for both teachers and administrators, there are not formalized procedures to certify that the content of education is fused with the ability to convey it to students.

There are tacit assumptions that those who are good teachers will make good administrators, and that successful administrators can help administrative aspirants through sharing of craft knowledge. These assumptions may be open to challenge.

Year-long, fifth-year internships for certification and induction programs for beginning teachers 
have been established in response to some of the concerns about the state of education expressed in recent reports. In Oregon, some induction programs for teachers have been funded at the state level. While there has been no parallel program for administrative aspirants, the concept of mentoring has taken hold. The oregon Mentorship Program has been the focus of this study. The study explored the dynamics, perceptions, expectations, and outcomes of the program after its first four years of existence. The reader is reminded that it was not possible to infer causality in this study; the nature of the program design did not control for this threat to validity. Nevertheless, the inability to quantify all phenomena was not sufficient to leave them unexplored.

The challenge to public education in this country has been serious. It has almost become fashionable to disparage the reputation of public schools. The simple fact is that if we are not willing to certify competence in teachers and administrators, someone else will. Their methods may not be in the best interest of either students or the public. It was, therefore, important to look at one design for providing a training ground for administrative aspirants in terms of the design's history and perceived results. To the extent that the oregon Mentorship Program can be characterized as successful, given its aim to help prepare 
aspirants for administrative positions, we will be prepared to better deal with critics of public education.

The review of the literature provided a means of examining existing mentorship paradigms in this country. The literature provided a backdrop for the examination of the oregon Mentorship Program. The question was not whether administrative skills will be examined but rather a question of who will do so. Teaching is neither a science nor an art; it is an amalgam of the two. In the same way as the nature/nurture controversy has been expressed, the question of science and art in teaching is before us. The study of the oregon Mentorship Program may have helped to answer the question of what administrative skills can be taught by practitioners in the field and which essential attributes are innate in individuals. If mentoring in education is an idea whose time has come, then it is a timely subject for study and discussion.

\section{LIMITATIONS}

One must be aware of limitations which may be inherent in the design of any study. In an attempt to caution readers in advance, concerns have been noted at the outset of this study. However, most of the concerns may be inherent in any descriptive study reliant on sample response. 
Descriptive research involving self-reporting may suffer from lack of response. Even when stamped return envelopes are provided, many people do not fill out and return questionnaires. In that case, it would be difficult to interpret findings since those not returning the questionnaire may feel greatly different from those who did respond. The problem is one of ability to generalize the results and, therefore, a threat to external validity. Conversely, because the respondents were all educators in oregon and because they may have felt a commitment to supporting agencies and organizations of the Mentorship Program, there may have been a higher number returned than if they were randomly selected from a larger population. Threats to internal validity such as maturation, effects of testing, statistical regression, and selection/maturation were not apparent in this study. The threat to validity of mortality could have been a factor if a number of individuals discontinued their participation or were not actively involved during the mentorship year; although this number was smali, these individuals may have shared a common characteristic and, therefore, their absence or limited participation may have had an effect on the results of the study.

The control of variables is a factor in any study, and the researcher and reader must be aware that this project could not demonstrate causal relations. For example, just 
because a protege secured an administrative position during or at the conclusion of the year-long mentoring experience, there was no supporting evidence to say that the new position attained was related to the mentoring project and his/her participation.

Veracity of the respondents could be a factor. It is assumed that mentors and proteges answered honestly but there is always a chance that political motives may have overshadowed one's response. Because the responses were compiled in such a way as to not identify any one individual or employing district, this may not have been a factor of concern.

\section{DEFINITION OF TERMS}

ADMINISTRATOR: This term referred to certified educators, actively engaged in school administration, and holding a position described as assistant principal, principal, administrative office director or district coordinator, assistant superintendent, or superintendent. Because this study focused on oregon, all administrators held an Administrative Certificate from the Teacher Standards and Practices Commission. In this sample, mentors were administrators.

ASPIRANT: This term referred to the person presently in an educational administration training program or one who recently completed such a program, and who is actively 
pursuing a position in school administration. For this study, an aspirant was a person who aspires to a career change from teacher status to administrative status or from an entry level administrative assistant position to administrative status. In the study sample, proteges were considered aspirants.

INDUCTION: This term refers to a process for developing among new members of an occupation the knowledge, skills, attitudes, and values essential to carrying out their roles effectively. Induction is aimed at helping new members internalize the norms of their role (Rogus, 1988). Teacher induction programs have received a significant amount of attention in the literature and in numerous school districts; in contrast, administrator induction programs or processes have received little attention until very recently.

MENTOR: According the Thesaurus of ERIC Descriptors (1990), "mentor" refers to the:

trusted and experienced supervisors or advisors who have personal and direct interest in the development and/or education of younger or less experienced individuals, usually in professional education or professional occupations. (p. 161)

"Mentor" is defined in Webster's Third New International Dictionary of the English Ianguage Unabridged (1986) as "a close, trusted, and experienced counselor or guide." In this study, "mentor" referred to the practicing oregon school administrator considered to have exemplary skills and 
knowledge, and who was considered by peers to have the ability to transfer those skills and that knowledge to others.

MENTORING: This term refers to a process by which a trusted and experienced supervisor or advisor takes a personal or direct interest in the development and education of a younger or less experienced individual (Thesaurus of ERIC Descriptors, 1990). "Mentoring" is a highly complex people-related skill, involving comprehensive concern for life-adjustment behavior. Mentoring is an ancient concept traceable to Greek mythology.

MENTORSHIP: This term refers to a cooperative arrangement between two people that exists to share practical experiences, knowledge, and expertise on the part of the mentor that are designed to enhance the professional and personal growth of the protege. In this study, the "mentorship" was the formal match-up of an administrative aspirant and a practicing school administrator, specifically as it related to the oregon Mentorship Program.

RROTEGE: This term refers to one who feels his/her pexsonal or professional growth was or is fostered by another (Krupp, 1985). "Protege" is derived from the French verb "proteger" meaning "to protect." In this study, a "protege" was the aspiring or beginning administrator who had applied and had been accepted into the oregon Mentorship Program between the years of 1986 and 1990. 
PURPOSE OF THE STUDY

The purpose of this descriptive study of the Oregon Mentorship Program was to conduct an in-depth analysis of the program as a process which was aimed toward the global goal of improvement of instruction. The writer believed that society has been engaged in study of a great number of possible ways to improve education. The effort to study which has been made, combined with the recognition of the need for change, is laudable. Education should continually change to meet the needs of the dynamic society. Inappropriate assumptions have sometimes been made, however, regarding the outcomes of change in education. It does not necessarily follow that if we improve particular educational elements, such as, training administrators to be better managers, that student performance will automatically improve. Promulgation of this pattern of assumption was not the researcher's aim. This study's purpose was to look at one element (the Oregon Mentorship Program) in a possible equation of the improved preparation of administrators that is aimed toward developing more effective teaching staffs who, in turn, teach more effectively to students who will demonstrate improved academic and social performances. The researcher intended to look at the perceptions, structure, logistics, and participant relationships of the mentor and protege participants in the oregon Mentorship Program as a preliminary step in the analysis of a possible 
relationship between more skilled administrators and improvement of education. Mentorship programs in all venues presume that the association between the mentor and protege will result in some measure of "quality control" for those who have been mentored. For this reason, the researcher intended to examine as many possible components that either supported or detracted from the mentorship experience. The elements to be studied included all that have been discussed in the current literature in the field, such as, whether gender mitigates success, contact frequency as a factor, and mutual goal setting.

This descriptive study of the Oregon Mentorship Program actually had four components; one was to describe those activities and characteristics of the program that had usefulness and were perceived as being successful or deleterious experiences by the mentors; secondly, the same components were analyzed from the viewpoint of the proteges; thirdly, the researcher felt that it was important to compare the mentor responses to the protege responses to see where concurrence and divergence occurred in evaluation of the same program components. These comparisons, both among and between mentors and proteges were aimed toward the fourth component of this study: to provide guidance for those individuals responsible for educational administration programs in an effort to prepare more effective school administrators. 
CHAPTER II

REVIEW OF THE IITERATURE

Mentorships or apprenticeships have been a route into many professions for centuries. Over the past decade, data on the incidence, properties, and dynamics, and on individual, interpersonal, and organizational outcomes of the mentor/protege relationship have been steadily accumulating. The literature on mentorships in the medical fields, business world, and skilled trades is abundant. Literature on mentoring as an induction process into education has focused only on teachers until very recently. Presently, there is a growing commitment to create formal mentorship programs where the administrative aspirant has an opportunity to share in the practical experience and wisdom of successful school administrators. According to Schmuck, Giannone, and Robbins (1991), the value of mentorships as part of the training to be a school administrator is further supported by realizations that:

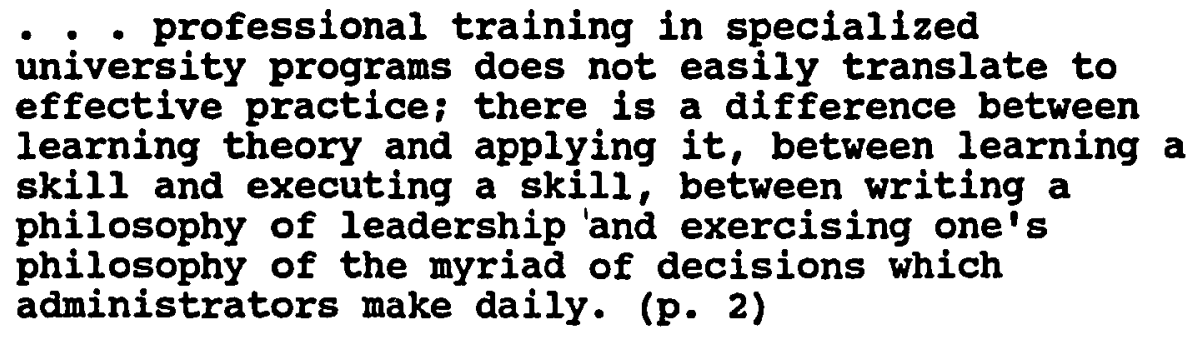


This chapter consists of a review of the literature concerning the dimensions of mentoring: importance of formal and informal mentorships, mentor-protege relationships and expectations, induction processes in education, and mentorships in educational administration. The literature on mentoring is found in a wide variety of source materials. While there are relatively few books on mentoring, there are numerous periodicals and educational, business, and sociological journals. In addition, there have been a number of dissertations, theses, speeches, and seminars on induction processes and various mentoring relationships. Literature is prevalent concerning role models, the patron system, cloning in academe, career immobility of women within the corporate structure, cross-gender mentoring, mentoring relationships in mental health careers, tokenism, and docents.

This chapter is organized as follows: section one, literature concerning mentoring in general including definitions; section two, mentor and protege relationships and expectations of informal and formal mentorships; section three, the mentoring of beginning educators through induction processes; and section four, mentors and mentorships in educational administration. 
THE CONCEPT OF MENTORING

Although the concept of mentoring appears to be new to public education, the phenomenon has its origin in Greek mythology. Odysseus entrusted his son, Telemachus, to a trusted counselor and friend named Mentor. Mentor became the counselor, guide, coach, sponsor, and tutor to his protege, Telemachus (cited in Hamilton, 1942). Mentorships have emerged as a concept of significant interest concerning adult development and career development. Interest in mentoring initially has been a focus of the business world and medical fields; more recently, education has incorporated mentoring as a component of the teacher induction process. Within the last few years, mentoring is a concept being explored to help ease aspiring or beginning administrators into their new roles. According to $\operatorname{Kram}(1985 \mathrm{~b})$, a mentor is an experienced, productive manager who relates well to less-experienced employees; the mentor facilitates the protege's personal development for the benefit of both the individual and the organization.

Most mentorships are informal; the relationship consists of two people who are interested in creating a relationship. There is evidence that formal mentorships, where the organization assigns or develops a process for matching mentors with proteges, are increasing in number in the private and the public sectors (Klauss, 1981; Noe, 
1988a: Roche, 1979). For example, there are numerous examples of formal mentoring programs in the medical fields, including programs during medical training and early career stages (Calkins, Arnold, Willoughby, \& Hamburger, 1986; Campbell-Heider, 1986; Flach, Smith, Smith, \& Glasser, 1982 ; Hagerty, 1986; Miller, Thomson, \& Roush, 1989; Ochberg, Tischler, \& Schulberg, 1986; Rogers, 1986) along with considerable research on the effectiveness of cloning in academe and the impact of mentoring and collegial support on faculty success (Blackburn, Chapman, \& Cameron, 1981; Hill, Bahniuk, \& Dobos, 1989; Yoder, Adams, Grove, \& Priest, 1985) and mentoring in psychology graduate training (Cronan-Hillix, Gensheimer, Cronan-Hillix, \& Davidson, 1986; Swerdlik \& Bardon, 1988). Summarizing research by Noe (1988a), Phillips-Jones (1983), and Zey (1985), successful formal mentoring programs are characterized by top management support, careful selection of mentors and proteges, an extensive orientation program emphasizing the development of realistic expectations concerning the relationship, clearly stated responsibilities for both the mentor and protege, and established minimums of duration and frequency of contact between mentor and protege.

Although there is little quantitative research concerning the benefits of mentoring, it is commonly held that mentors may provide career and psychosocial benefits to the protege (Burke, 1984; Kram, 1983, 1985b; Zey, 1984). 
The mentor may advance the protege's career by sponsoring him/her for promotion, by providing exposure, visibility, and opportunities to exercise special talents, by recommending strategies for completing a task or an objective, by protecting the protege from controversy, and by challenging the protege to do his or her best work. In addition, the mentor may serve as a role model, a sounding board, and a counselor. Mentorships may be a significant factor in organizational success; according to Roche (1979), mentorships may promote career satisfaction. These philosophies suggest that advancement to powerful positions in organizations may be related to or dependent upon successful development of mentoring relationships. Mentoring relationships are generally long in duration (Rawlins \& Rawlins, 1983), and include a substantial emotional commitment by both the mentor and the protege (Shapiro, Haseltine, \& Rowe, 1978). Kram (1985b) and Roche (1979) generally defined mentors as higher ranking, influential, senior organizational members with advanced experience and knowledge who are committed to providing upward mobility and support to a protege's professional career.

Mentorship is a career training and development tool in many occupations, such as, physician and intern, master and apprentice, and teacher and student. Many corporate presidents have had mentors who were vital to their success. 
In a study by Roche (1979), two-thirds of the prominent executives had mentors and these executives received higher salaries, bonuses, and total compensation than did executives who did not have mentors. In some organizations and government agencies, the mentor role has been formalized with the expectation that the mentor will advise new "fast track" recruits on career matters (Hunt \& Michael, 1983). It may also be a piece of the developmental ethic in business today where managers are responsible for developing talent which may make serving as a mentor professionally rewarding.

Organizations generally benefit from mentor/protege relationships (Kram, 1983). Mentorships aid in the development of managerial talent including the teaching of technical skills, the organizational culture, and a sense of competence. Mentorships may also serve to rejuvenate older professionals by passing on wisdom and expertise (Hunt \& Michael, 1983; Krupp, 1985). Companies such as AT\&T, Merrill Lynch, Federal Express, Motorola, Johnson and Johnson, Colgate-Palmolive, and $3 \mathrm{M}$ have introduced formalized mentorship programs; these companies place a high premium on managerial training and development (Serlen, 1989; Zey, 1984). On the other side, there are career development specialists that believe that a formalized mentoring program is unnecessary because "individuals can learn from the intellectual, interpersonal and career 
management behavior of their immediate supervisor" (Clawson, 1985, p. 39).

Levinson, Darrow, Klein, Levinson, and McKee, (1978) in their study of middle-aged men, considered the relationship with a mentor as complex and developmentally important. According to Levinson et al. mentors appear at times of change in a person's life, stay through the transition, and depart as the change is completed; the mentor helps form a "dream" of who and what one wants to become along with offering support, advise, challenge, and hope. Although the Levinson et al. work was exclusively based on a male sample, recent evidence suggests that men and women may differ in how they learn and how they view their mentoring relationship (Clawson, 1985; Daloz, 1983; Kram, 1985a, 1985b; Noe, 1988a, 1988b; Ragins, 1989). Mentoring has evolved through the years to mean "guardian": mentoring may be likened to a mixture of a parent and a peer (Borman \& Colson, 1984). But becoming a parent or a mentor does not ensure effectiveness in those roles. According to Noller (1982), certain strategies add to effective mentoring; these strategies are positive attitude, valuing, open-mindedness, interrelations, creative problem solving, effective communication, discovery, strengths and uniqueness, confidence, awareness, risk-taking, and flexibility. Lea and Liebowitz (1983) considered mentoring to be an integrative process using 
behavioral terms. The ten behaviors that mentors perform are teaching, advising, guiding, sponsoring, counseling, role modeling, motivating, validating, protecting, and communicating. It is generally thought that new employees hold potential to become the new life and energy of any organization (Fagenson, 1988). Although most organizations offer some type of orientation or process of integration, an increasing number are seeing the benefits of mentoring as an integral part of the personnel development program (Clark \& zimmer, 1989). Mentoring, as a sharing relationship, focuses on the protege's strengths and interests and results in benefits for the protege, mentor, and the organization. According to Zey (1984), the protege receives knowledge, support, protection, and promotion; the mentor realizes loyalty, information, prestige, and possibly assistance on the job; the organization achieves managerial succession, managerial development, reduced turnover, and increased productivity.

In a study of the Ohio Cooperative Extension Service, clark and zimmer (1989) determined that the critical outcomes from the organization's mentor/protege meetings for both the mentors and the proteges were: perceived program planning, understanding the organization, utilizing mentor expertise, and gaining a friend. In addition, clark and zimmer determined that there were certain practices that anyone developing or monitoring a mentoring program would 
want to consider. For the mentors, these included: some basic guidelines and training prior to the initiation of the relationship that would help to target organizational expectations and add direction to what was to be accomplished, some basic understanding of what factors lead to success, such as, training related to creating open communication and basic personal communication to help build a trusting relationship; close geographical locations to facilitate visitation, early establishment of the mentoring relationship in the protege's employment, and organizational expectations that are realistic as to the type of information transferred. It should be noted that clark and zimmer stressed the importance of the mentor's making the initial contact with the protege to demonstrate interest: they also stressed the importance of the mentor's dedication to mentoring and, therefore, willingness to dedicate the necessary time.

According to Farren, Gray, and Kaye (1984), "Career development programs that encourage still higher levels of management to become involved can increase the payoff even further by adding the mentor component" (p. 20); they describe a mentor's activities in an acronym to include: manage, encourage, nurture, and teach organizational responsibility. Although informal mentoring goes on daily and usually includes rather low expectations from the protege's point of view, formal mentoring programs need to 
be closely monitored to reduce or eliminate problems such as relationships that never develop and protege expectations that are unrealistic as they relate to the volunteer mentor's time availability. According to Farren et al., a formal program for proteges also "perpetuates the myth that a mentor is required in order to succeed" (p. 20), which may make those individuals without mentors feel jealous or deprived.

At Merrill Lynch, mentoring was added to the Management Readiness Program (MRP), a six-month career development program, to help generate high level management support and visibility, build bridges between personnel levels, teach the firm's culture, increase networking, and as an opportunity to showcase talented people developers (Farren et al., 1984). Some guiding principles from the Merrill Lynch program are: to make sure that the volunteer mentors are truly committed to the program and can afford the time; to minimize the "rules" and to maximize the mentor's personal freedom to find what works for him/her after the initial briefing, to create expanded networking opportunities for the proteges, to share, negotiate, and determine expectations for both the mentor and the protege, to design rewards and recognition for the mentors, and to create ways to engage the protege's direct supervisor in the mentoring relationship to eliminate competition and gain insight into the protege's daily work routine (Farren et 
al., 1984). According to Burke and McKeen (1989), mentorships must address the primary and secondary goals of the program, top management must be supportive, and strategies for attaining the program goals must be defined. Mentoring is described by Mumford (1985) simply as "the process of nurturing the growth of other people within their jobs" (p. 31). He explains that:

- . like many of the best management development ideas, it [mentoring] describes a process long familiar to experienced managers but substantially unrecognized and under-used . . . [he is] in favour [sic] of making use of the real management world instead of forcing people into an educator or trainer world. (p. 31)

Mumford writes that because:

- . most management development occurs on the job through a variety of unstructured and often accidental processes.. . the focus should be on what managers do and how they can be helped to learn from what they do. (p. 30)

In the view of Mumford and others, mentorship should be recognized as crucial for the kind of self-managed learning process often referred to as self-development, action learning, or the general on-the-job-training.

According to Dix (1990), vocational psychology researchers and practitioners are now focusing on the issues of career success as an outcome of career adjustment instead of focusing on the stages (exploration, establishment, maintenance, and decline) of career development. During one stage of career development, that of establishment, mentoring has been linked with managerial and career success 
because of the sharing of tacit knowledge from those who have successfully negotiated the system to those who are currently entering it. Hamilton (1989), in a study concerning apprentices or learning on the job, discusses the positive contribution that mentors make in a career and the "disadvantages to women who lack powerful mentors as 'sponsors'" (p. 3) as key issues in the work place. Hamilton considers the minimum criterion for success is having "someone be available as a mentor" (p. 3). He discusses the role of the mentor and includes such behaviors such as instructing, demonstrating or modeling, coaching, explaining why, challenging, initiating the protege into the culture of the organization, and affirming the learner's personal and professional values. From the vocational literature, it seems that there are a number of psychosocial functions that a mentor enables a protege to clarify, such as, his/her sense of identity, a greater sense of competence, and improved self-worth (Kanter, 1977; Levinson et al., 1978; Schockett \& Haring-Hidore, 1985). During the last fifteen years, managers and their employing organizations have become increasingly interested in the career development processes. The interest has increased because of the problems that organizations are experiencing such as developing enough talented managers to replace retirees (Burke, 1984), assisting managers caught in the wrong job, maintaining high levels of managerial 
contribution through middle-age and beyond (Krupp, 1984), and reducing turnover in early career stages. According to Burke, "a crucial role in career development is played by one's mentor" (p. 353). Mentors are linked with managerial and career success (Roche, 1979), the process of developing leaders as opposed to managers (Bennis \& Nanus, 1985), and early socialization. Hennig and Jardim (1977) reported that all of the successful female managers in their study had a male mentor who performed significant functions in their careers. Levinson et al. (1978) in Seasons of a Man's Life highlighted the important role played by mentors in the lives of the sample of $40 \mathrm{mid}-1$ ife men.

The phenomenon of mentoring seems to be pervasive in the work setting. Hunt and richael (1983) in their framework for mentoring in organizations say mentoring makes an impact (as does its absence) and has a direct influence on job performance for both the mentor and protege, early socialization, long-range human resource development planning and managerial succession, and preparation of leaders. It appears to be generally agreed upon by researchers of personnel, career, and organizational development (Burke, 1984; Carden, 1990; Kanter, 1977; Levinson et al., 1978; Roche, 1979; Zaleznik, 1977) that individuals who have had mentors may be more successful in their careers; mentors may make personal and organizational contributions throughout their careers; individuals with 
mentors are more likely to learn what it takes to stay with an organization; the fit of individuals to the organization is enhanced; turnover is reduced; the presence of mentoring ensures that individuals with potential are groomed for more senior positions; and the effective mentoring relationship offers a mini-course in leadership.

People who have been highly successful in their careers indicate that mentoring was a significant element. These top achievers may be described as effective leaders in that they both received encouragement and promotion mentoring and provided career-counseling to others. Their effectiveness may lie in their motivation to achieve and their ability to give and receive concerned guidance. From his experiences in top management in a large American corporation, willbur (1987) creates an analogy and mental image when he writes that mentoring is to the organization what the sequoia is to the forest:

Successful people say they have been mentored in the past and that they mentor others now. As HRD (Human Resource Development) leaders we must do what we can to encourage mentoring as a means to further transfer organizations into environments that constantly nurture and develop employees. I like to compare mentors and the mentoring process to sequoia trees.

The sequoia grows to be hundreds of feet tall and lives for more than a thousand years. Why does it grow to such proportions? For one thing, the tree feeds from its environment through its strong, deep, wide-ranging roots. But it doesn't just take from its environment; it also gives. By providing shelter and nutrition to neighboring plants and animals, the sequoia contributes 80 percent more to the forest environment than it takes. It drops its 
branches and needles to feed other life, enriching the environment in which it lives. My study suggests mentoring and achievement motivation do the same thing. As people receive mentoring's benefits, they grow and achieve. They also develop roots in their organization and begin to mentor other achievers, thus giving back more than they received.

But there's something else about sequoias and mentoring that carries equal importance, and it is so obvious that I missed it for years. A sequoia never stops growing. As long as it lives, it develops and contributes to everything around it. That is the real meaning of mentoring and achievement motivation. Both will help you and your organization continue to grow. (p. 41)

\section{MENTOR AND PROTEGE RELATIONSHIPS}

There is considerable agreement among those who have studied mentoring that in order to understand the nature and impact of the developmental relationship, it is imperative to be aware of how relationships change over time, how gender may play a role in the relationship, and how expectations may vary within formal and informal mentoring (Kram, 1983; Levinson et al., 1978).

A person in the first stages of his/her career may engage in forming mentoring relationships to increase role identity and reduce role confusion, to increase intimacy and reduce isolation, or to search out methods to achieve a future career dream (Kram, 1983). In contrast, the experienced adult in mid-career and/or mid-life may be reassessing past accomplishments and not confronting future challenges (Levinson et al., 1978). Entering a developmental relationship with a first-stage career person 
may create energy and redirect the productivity of the mid-life person, creating the Eriksonian polarity in the life-stage, that of generativity versus stagnation (Kram, 1983). "Generativity is a concern for and an interest in guiding the next generation . . clearly, mentoring is one manifestation of this mid-life task" (Merriam, 1983, p. 163). According to Gladstone (1988):

While mentors nourish their saplings (mentorees) they also receive rewards making them feel that their own lives are worthwhile. Mentoring helps them feel part of a greater whole and intertwined with all living things and is sometimes described as a deeply-moving, almost religious experience. often mentors feel that the satisfaction and benefits exceed their investment of time and energy. (p. 21)

Shapiro, Haseltine, and Rowe (1978) offer a continuum of advisor/support relationships which facilitate access to positions of leadership, authority, and power in management and professional fields; one end is the peer pal relationship; on the other end is the mentor relationship. The categories of the "patron system" are: a "peer pal" with the sharing of information, strategies, and mutual support with someone at the same level; a "guide" where the person explains the system but is not in a position to champion a protege; a "sponsor" who is supportive but is less powerful than a patron in helping to promote the career of the protege; a "patron" is an influential person who uses his or her power to help the protege advance; and a "mentor" who establishes an intense paternalistic relationship where he or she assumes the role of both teacher and advocate. 
According to Pence (1989a), in a study of formal and informal mentorships in oregon:

Successful mentorships required a strong commitment to the relationship from both mentor and protege. Individuals in successful dyads take their relationship seriously almost like a marriage or family relationship. The fact that informal mentorships were established in the first place demonstrates a high level of commitment by members of the dyads. The success of a formal mentorship is particularly dependent upon commitment from both parties. They make sure they schedule time to discuss philosophical education issues and day-to-day situations. (p. 166)

According to The Woodlands Group (1980), an informal association of training and development specialists from Woodland, Texas, effective managers can be trained by other employees acting as coaches, sponsors, and mentors. In the coaching relationship, the supervisor helps the subordinate meet specific growth needs by setting challenges, communicating expectations, counseling, appraising subordinates regularly and objectively, providing positive feedback, having the subordinates ready to fill in his or her absence, and preparing the subordinate for promotion. The coaches' pleasures are likely to be intrinsic: e.g., the pleasure of watching growth and success of proteges; the negative aspects may be in losing their best employees to promotion. Organizations that want good coaches must continue to reinforce those who coach well. In the sponsorship relationship, the sponsor discovers and fosters individuals for enhanced placement. The sponsor secures individuals' names on the promotion lists, gets individuals 
on assigned task forces and committees, mentors individuals for specific openings, applies subtle pressure to secure desired assignments, advises the protege on how to secure a position, publicly promotes the protege, and actively seeks promotional opportunities for the protege. Sponsors must command credibility, along with insight, influence, and knowledge about the informal values and practices of the organization; sponsors who can identify high-potential employees often enjoy a "halo effect" when their proteges succeed. This may explain why proteges do not commonly work directly for their sponsors. The members of The Woodlands Group write:

A serious result of being sponsored is the feeling that promotions are not linked to performance: entire generations of proteges may feel (with some truth) that they work for a political organization where it is not what you do but whom you know. Finally, sponsors may urge proteges into assignments not directly matched with the skills or interests of the protege and the next step upward is rendered difficult or even impossible. (p. 920)

In the mentor relationship, the mentor is the most significant, and the subtlest, of the three roles in management development. Mentors must possess a wide knowledge of the organization, both informal structures and processes, to be effective and to be perceived as valid. Effective mentors are both self-appointed and formally matched. Mentors must possess genuine generosity, compassion, and concern; they "must hear feelings as well as ideas" (p. 920). Caring is the core of the mentoring 
relationship. Since "wisdom can be imparted only when receivers seek it or are willing to listen" (p. 920), the protege is actually in control of the relationship. This poses a risk for the mentor. The mentor relationship has the potential to enhance career development and psychosocial development of both the mentor and the protege. Career functions are those aspects of the relationship that primarily enhance career advancement; psychology functions are those aspects of the relationship that primarily enhance sense of competence, clarity of identity, and effectiveness in the managerial or work place (Bowen, 1985; Kram, 1983).

In a study set in a large northeastern public utility, Kram (1983) researched developmental relationships of pairs of younger and older, protege and mentor, managers. She examined such career functions as sponsorship, exposure and visibility, coaching, protection, and challenging assignment. In addition, such psychosocial functions as role modeling, acceptance and confirmation, counseling, and friendship were examined. Although the relationships under study varied in length (the average length was five years in the sample), each proceeded through generally the same four predictable phases. These phases included an initiation, where the relationship is started and where the protege admires and respects the mentor and feels supported and cared for; the cultivation phase, where positive 
expectations emerge, the real value of relating to each unfolds, and career and psychosocial functions peak; the separation phase, where the established nature of the relationship is substantially altered by structural changes within the organization and/or psychological changes within the pair; and the redefinition phase, where the relationship evolves as a new form, such as friendship, or the relationship ends.

Establishing effective mentoring relationships is not a simple and clear-cut task. Although most researchers of the concept and practice of mentoring feel strongly that mentoring has the potential to benefit the mentor, the protege, and the organization (Burke \& Mckeen, 1989; Farren et al., 1984; Hill et al., 1989; Jacoby, 1989; Noe, 1988a; Phillips-Jones, 1983), some writers think that the risks of formal mentoring programs may outweigh the benefits, partly because it is difficult or impossible to force mentors and proteges into a mentoring-type relationship (Keele \& DeLaMare-Schaefer, 1984; Kizilos, 1990; Kram, 1985b). In addition, Kram writes that often those not selected for mentoring may feel resentful and pessimistic about their careers; those selected for participation may feel burdened by the new responsibility; and immediate supervisors may feel threatened by the program. According to Fagenson (1988), drawbacks could include:

resentment from individuals who do not have mentors, attention directed toward the mentor-protege 
relationship and away from the organization, and a protege's overdependence on the mentor-who can take unfair advantage of him or her. (p. 192)

Mentoring programs often may fail because of organizational cultures that do not value personal development. Reich (1985) cites the danger that people may not necessarily see how to view the protege as a separate individual from the mentor. In addition, one's mentor could fall out of favor making it difficult for the protege to be recognized. Most agree though that with careful attention to a systematic diagnosis of the obstacles, an improved organizational development approach, and collection of data about the factors that promote and inhibit developmental relationships, programs can be successful and, therefore, a benefit to participants and the organization.

Alleman, Cochran, Doverspike, and Newman (1984) found mentoring to be a behavioral phenomenon not dependent on personal traits. They concluded that mentoring relationships can be established or enriched by learning or encouraging mentor-like behavior rather than selecting certain types of individuals to serve as mentors. In addition, they found it unnecessary to match pairs on various characteristics or to avoid cross-sex pairing as many researchers have suggested (Hennecke, 1983; Johnson, 1980; Lea \& Leibowitz, 1983; Zey, 1984). Keele and DeLaMare-Schaefer (1984) concluded from two separate studies that whether or not a person has had or has 
a mentor, career benefits can come from their being a mentor and building a work team. These benefits included job advancement, added control of the work environment, creating a support system, gaining more access to system resources, developing a reputation, and personal satisfaction. Reciprocity seems to underlie all aspects of developing proteges. They concluded that people who do not have a mentor should become a mentor; rather than try to find a mentors or feel that their careers were slowed or halted, people should recognize that being a mentor is a legitimate career stage. Keele and DeLaMare-Schaefer state that "Beginning to be concerned for others is an important stage in one's career development. At the ultimate level, we help our own career by helping others" (p. 40).

Informal mentoring relationships, those that are not monitored and function on an individual basis, can and do benefit the participants. Co-mentoring is an intense mutual mentoring relationship that is common among peers but transcends age, rank, and organizational level boundaries (Mcsser, Deady, Kleisner, 1989). Formal mentoring relationships may be more beneficial in more cases but require monitoring to help reduce problems of poor chemistry, expectations that are unrealistic, and perpetuation of the myth that people must have mentors to succeed (Auster, 1984; Farren et al., 1984; Gerstein, 1985; Keele \& DeLaMare-Schaefer, 1984). Phillips-Jones (1983) 
indicates that the majority of mentoring relationships are informal, developing because of shared interests, admiration, or job demands. In informal mentoring relationships, discussions between the mentor and protege usually go beyond career-related issues to more in-depth personal sharing of interests, needs, and values (Noe, 1988a).

There are numerous factors that influence the development of a successful, assigned (formal) relationship. According to Noe (1988a), protege characteristics that influence the development of a successful mentoring relationship are locus of control, job involvement, career planning, and relationship importance; in addition, gender composition of the mentoring dyad may influence success.

Locus of control is a stable personality trait that may affect individuals' motivation to participate in developmental activities; individuals with internal locus of control believe that job performance and events in the work setting are contingent on their own behavior and under personal control; individuals with external locus of control believe that work outcomes are beyond personal control and attributable to fate, luck, and the actions of other people. Noe (1988a) believes that internals will spend more time with their mentors and will utilize more effectively the mentors than will externals. 
Job involvement is the degree to which an individual identifies psychologically with work. An individual's interest in developing skills may be dependent on how important his/her job is for self-image, enthusiasm for work, and the importance placed on work-type activities versus non-work activities. Noe (1988a) believes that the greater the protege's level of job involvement, the more time the individual will spend utilizing the mentor.

Career planning refers to mental or physical activity spent eliciting information about self-assessment of skill, career values, interests, goals, and searches for job related information. Noe (1988a) believes that the greater the extent to which the protege engages in career planning, the more time the individual will spend with the mentor.

Relationship importance refers to gaining social support through the relationship with peers and supervisors (Noe, 1988a) which may also facilitate organizational socialization, reduce job stress and work demands, and aid in personal and professional development (Kram \& Isabella, 1985; Levinson et al., 1978). Quality of interaction and time spent with the mentor relates to the career and psychosocial benefits obtained from participating in a mentoring relationship and utilization of the mentor's time for effective outcomes (Kram, 1985a; Noe, 1988a).

The gender composition of the mentoring/protege dyad may influence the effectiveness of the relationship. Noe 
(1988a) indicates that the development of successful cross-gender mentorships may be inhibited by:

perceptions that women lack managerial skills and are unsuitable for challenging positions, preferences for interaction with members of the same gender in the work environment, and concerns that peers may perceive the mentoring relationship as sexual in nature, leading to resentment and malicious gossip. (p. 463)

According to Fagenson (1989) and Kram (1985b), female proteges are more likely to experience greater social distance, discomfort, and overprotectiveness than male proteges from male mentors. However, Kram and Fagenson found that outcomes appear to be similar; the traditional favorable job/career outcomes may be negotiable and attainable with the help of a corporate "godfather" or mentor.

Although most of the mentoring models are based on the white male experience, mentorship may be equally, if not more important for women (Reich, 1986; Wright \& Wright, 1987). In studies of successful women, mentorships have been cited as a critical factor in their success (Bowen, 1985; Merriam, 1983; Missirian, 1982). However, there is a shortage of female mentors in business, academia, and other professions (Haring-Hidore, 1987; Shapiro et al., 1978). Research suggests that mentors are more comfortable with proteges with whom they identify, and identification is likely to depend on gender, race, and social class (Shapiro et al., 1978). For this reason, many women and minorities 
lack mentors who might be instrumental in their careers. In addition, mentors and proteges in cross-gender pairing may be at risk for gossip, jealous spouses, and sexual attraction or tension (Missirian, 1982), According to Clawson and Kram (1984),

Taking an active part in the growth and development of a subordinate can result in growing concern, liking, and admiration. Channeling these feelings into a productive professional relationship without falling into the pitfalls caused by excessive intimacy requires thoughtful management . -

At the other extreme of the intimacy continuum are relationships that are unnecessarily cool and distant . . [ [which] reduce the learning for subordinates. Subordinates may conclude that the boss does not care or even know about them, and this can be demoralizing. (pp. 25-26)

Participants in a male/female mentoring relationship may have to deal with stereotypic male/female roles as well (Clawson, Kram, 1984). Not all researchers of women and mentoring agree; Chao and O'Leary's (1990) study suggests that these problems of cross gender mentoring may be exaggerated. Despite some possible drawback, authors recommend that women find themselves a mentor. Sheehy (1976) states that "almost without exception, the women I studied who did gain recognition in their careers were at some point nurtured by a mentor" (p. 34). Perhaps the strongest evidence for the importance of mentors to women in business comes from Hennig and Jardim (1977); in a study of 25 top-level women executives, all had had a mentor; in each case, the mentor was a male boss; in each case, the 
relationship was emotional, intense, but not sexual; all depended on their mentor until approximately age 35 .

As women enter traditional male-dominated career fields, their choices of mentors may be affected not only by their gender but by their age as well. According to Hunt and Michael (1983), some women may make career choices later in life than men, making the male linear model of life/career cycle less plausible. According to Gray (1986),

To make sure that women and minorities, after gaining access to good jobs, will succeed at them, an intentional, systematic, affirmative action program is needed. One of the best involves formalized mentoring . . (p. 636)

THE IMPACT OF MENTORING WITHIN THE TEACHER INDUCTION PROCESS

The concept of mentoring in educational administration may have evolved from the teacher induction process. Collegial mentoring, typically utilized to facilitate the induction of new teachers into the profession, may also serve as a developmental program for veteran teachers. The idea of teachers learning from teachers is not new, genuine mentoring is not often found within educators' ranks. In recent years, many attempts have been made to utilize the concept of mentoring to reduce teacher isolation and to cultivate collegial interaction and assistance for teachers.

Although the body of literature on new teachers' needs and feelings has a lengthy history (Homeier, 1953), published research on induction programs spans approximately 
the last decade. In fact, according to stewart (1986), the term has been used as a descriptor in ERIC data base for fewer than seven years. According to Huling-Austin (1986), exemplary programs have realistic goals to:

improve teaching performance. . to increase the retention of promising beginning teachers during the induction years . . to promote the personal and professional well-being of beginning teachers.... and to satisfy mandated requirements related to induction and certification. (pp. 2-4)

Although documented research proving the value of specific induction programs as shown in teacher competence is scant, the qualitative research is clear as to the advantages of doing something more than mere orientation for beginning teachers (Galvez-Hjornevik, 1986; Hoffman, Edwards, O'Neal, Barnes, \& Paulissen, 1986; Huling-Austin, 1986, 1988; Huling-Austin \& Others, 1989; Isaacson, 1986) . clewett (1984) summarizes a review of related literature on needs of beginning teachers into three categories: teacher reflections, descriptive surveys, and psychosocial research. Spanning the time period from the 1930 s to the present, clewett emphasizes the consistency of beginning teacher needs in:

\footnotetext{
- disciplining, managing, and motivating students; preparing and organizing work, locating materials and resources; individualizing assessment and instruction . . . enlisting timely and appropriate assistance from school personnel; establishing relationships with colleagues, and adjusting work and leisure time in the face of pressing time constraints. (p. 8)
} 
Since the conant (1963) report and clewett's (1984) summary notes the necessity for addressing the particular needs of beginning teachers, a number of studies has dealt with the topic. In general, the findings support the idea that an induction process is critical and, according to Huffman and Leek (1986) and Harper (1988), is a reasonable approach to solving the problems inherent in the new teacher's job. The studies, through teacher reflections, descriptive surveys, and psychological research, summarize beginning teacher concerns to include both instructional and noninstructional needs, professional and personal needs, and situation-specific or individually defined support needs. According to clewett, "The intensity, duration, and degree to which problems impinge on success during the induction year varies according to personal and setting characteristics" (p. 32). clewett, utilizing descriptive surveys, reports that beginning teachers received little formal support and were not proactive in seeking assistance, but that the lack of support did not solely or ultimately determine their decision to continue or leave the profession (p. 32). An important factor in the psychosocial research is the beginning teacher's socialization to the teaching role and setting, both formal and informal, including social norms. Beginning teachers' socialization concerns result in controlling behaviors and conventional beliefs, such as, seldom feeling prepared to deal with all people in the 
school setting, feeling isolated and reluctant to seek assistance, and fearing being seen as less than able, less than credible, or having less status (Clewett, 1984). These findings support the idea that an induction process is effective in helping beginning teachers adjust to the job, and relates the needs and concerns of beginning teachers to those similar needs and concerns of the beginning school administrator.

As a result of the push for excellence and an anticipated teacher shortage, programs consisting of induction processes, mentoring components, and/or coaching-type activities have become more prevalent in schools, districts, colleges and universities, and regional and state educational agencies. This thrust may help school leaders attract and keep the best educators, increase the odds for effective instruction, and assist those beginning educators with both cognitive and affective development.

Taking into account the previously cited research findings and in consideration of recent writing by Galvez-Hjornevik (1986) on mentoring, Showers (1982, 1984) on peer coaching, Fox and singletary (1986) on induction seminars that facilitate support and the development of reflective orientation and the skills essential to self-evaluation, and clewett (1984) on highly individualized assistance, the components of effective programs for the beginning educators have been identified. School 
administrators, school districts, educational training institutions, educational service agencies, and state agencies need to "visualize" how the process could become part of the "culture" of the educational profession (Bennis \& Nanus, 1985; Sergiovanni, 1984).

Teacher training is changing to meet the needs of their clientele; districts are incorporating induction processes, mentoring, entry year assistance programs, and/or peer-coaching programs; universities are collaborating with districts in a holistic approach to educating the teacher, and states are mandating beginning teacher internships and/or mentorships to help beginning teachers cope with the teaching environment. Teacher education in many states now includes a year-long internship instead of the eight-week student-teaching experience; training is moving toward a five-year approach to preparing teachers for the schools of this next decade. State, county, and service districts are collaborating to provide innovative approaches to preparing educators; many of these programs have as a pivotal component an intensive mentoring opportunity. Although in the last few years, teacher education has made great strides toward connecting theory with practical experience and in preparing the whole person for the job, administrators, school districts, educational organizations and agencies, and educational administrative programs are just beginning to recognize the value in mentorships and collaborative 
approaches to meeting the needs of aspiring and beginning school administrators.

\section{MENTORS AND MENTORSHIP PROGRAMS IN EDUCATIONAL ADMINISTRATION}

Recent educational reform movements emphasize the significant influence that administrators, specifically principals, have on creating excellent schools (Lipsitz, 1983; Sergiovanni, 1984). But the forces of leadership and excellence in schools may be marked by more than mastery of certain predetermined, essential fundamentals. Sergiovanni writes:

Leadership has several aspects, each of which contribute uniquely to school competence and to school excellence. The current focus in leadership theory and practice provides a limited view, dwelling excessively on some aspects of leadership to the virtual exclusion of others. Unfortunately, these neglected aspects of leadership are linked to excellence --- a revelation now unfolding from recent research on school effectiveness and school climate. (p. 6)

The leadership forces that Sergiovanni writes about include not only the knowledge about education and schooling, sound management techniques, and interpersonal skills, but the influence of symbolic leaders in modeling to others what is important and of value combined with creating a positive culture within the school setting.

In an in-depth study of informal mentorship dyads, Pence (1989a) states:

Relational characteristics must be established before operational activities and interactions can occur. 
Traits of trust, mutual respect, openness, and friendship are the most critical relational factors in successful mentorships and are common to informal and formal mentorships. Other activities and interactions of mentorships are based upon the degree to which those characteristics are present. (pp. 164-165)

Most educational administration training programs neither can nor should be expected to prepare aspiring administrators adequately for the multitude of responsibilities expected of practicing administrators. Although most programs include practica and/or internship opportunities, most beginning administrators report that they need and want more hands-on practice to assist them in their successful transition into an administrative role (Daresh \& Playko, 1989a, 1989b, 1989c; Playko \& Daresh, 1988; Rogus \& Drury, 1988; Shute, Webb, \& Thomas, 1989). In response to the research and expressed needs of aspirants and beginning administrators in oregon, a number of programs has emerged. Examples of innovative approaches combining theory and practice and/or working collaboratively with multiple institution, agencies, and/or districts are: the Institute for Executive Leadership for the training of superintendents within a five-term study group, the Leadership 2000 Program involving a one-year seminar approach combined with mentor component for aspiring school administrators, the Retired Administrators As Mentors Program, the Springfield Development Program for Aspiring and Practicing Administrators (Pence, 1989b), and the oregon Mentorship Program. These efforts by school districts, 
agencies, professional organizations, and preservice institutions are implementing mentoring programs and/or a seminar approach to learning in an effort to help ensure support and guidance for aspiring and recently-hired administrators.

Although it is clear that there are a number of ways in which mentorships for beginning teachers and beginning administrators are similar, there are also some important distinctions that need to be addressed. Daresh and Playko (1989d), in part through their association with the Danforth Foundation Program for the Preparation of School Principals, have noted that there are:

at least five characteristics of school administration that make it unlikely that an activity designed essentially for teachers will have a similar value for another group of educators. This is true if there is an attempt simply to transport practices used for teacher mentoring to the field of school administration. (p. 90)

Daresh and Playko (1989e) state that the research base on administration is not clear enough to guide mentoring relationships unlike recent teacher research on teaching behaviors to support desirable student outcomes. It may be some time before administrative mentoring will have access to a refined data base and the same kind of clear descriptions that are increasingly influencing the inservice education of classroom teachers. Administrators do not see each other very often. An effective feature of a mentoring program is the existence of spontaneity and frequent 
interchange between the mentor and the protege. Another feature is that the mentor should be an individual who has the same or similar job as the protege. Unlike most teachers, a principal or superintendent may be the only administrator in the building or even the district. This situation would clearly limit contact opportunities, eliminate spontaneity, and affect the time one may have for interaction. Most "new" administrators are not new to schools. Where mentors for beginning teachers spend a great deal of time showing the person what life is like in the school, almost all administrators have been in schools as teachers for at least three years. The role of the administrative mentor does not need to include an initial orientation to the field of professional education but may assist the administrative aspirant or first-year administrator with "a new dialect that is spoken in the same familiar land" (Daresh \& Playko, 1989d, p. 92). Because administrators are "formal leaders . . a position of formal authority, power, and control . . ." (Daresh \& Playko, 1989d, p. 92) mentoring may be more difficult for the mentor, for the beginning administrator and the teacher: mentoring will only be effective when it is understood that seeking support and guidance from others in the organization is an action that ultimately promotes strength, not weakness. (Daresh \& Playko, 1989d, p. 93)

The fifth characteristic noted by Daresh and Playko was that administrative "peers" usually are not true equals 
to the beginner. Whereas beginning teachers are newer to the profession but still equal to other teachers and their mentor, seldom is it possible to pair up truly equal administrators.

The goal is the establishment of a:

mutually-enhancing climate where both the mentor and protege can be perfectly open and honest with one another, to the extent that they may admit mistakes if necessary, and celebrate successes when they occur. (Daresh \& Playko, 1989b, p. 93)

There are two conditions that exist in school administration that tend to block the development of a truly open climate; one is derived from the formal structure of schools and the other is part of the informal structure. Within the formal structure, there are relatively few administrators in any school or district compared to teachers, making it difficult to locate a peer and, therefore, linking a protege with an administrator from higher levels of the hierarchy, and quite possibly a supervisor, e.g. principal with assistant principal, superintendent with principal. Daresh and Playko (1989e) note:

A principal and his or her assistant principal are all building level administrators and colleagues, and a climate of trust might be possible at first. However, this is likely to change abruptly when the principal is expected to complete an end of the year performance appraisal on his or her "peer." The type of openness that is so critical for effective mentor-protege interaction is hardly possible under such circumstances. It is a classical supervisory problem . . Even when the pairings of mentors and beginning administrators do not cross from one hierarchical level to another, the political reality 
in many school systems suggests that senior administrators often take on the role of superior to others . . . A second condition is . . principals are often competitors with other principals in the same system. When the scarce resources of a district are to be distributed, principals must compete with one another in order to get benefits for their staffs and students .. (p. 94)

Daresh and Playko (1989b, 1989d; 1990a, 1990b) stress that mentoring is valuable for beginning administrators. They do suggest that mentoring for administrators needs to place greater emphasis on the development of process skills that will assist the individual with the transition from teacher to administrator. They do not need to spend a great deal of time on understanding specific job-related skills and tasks.

The mentor must know the system, be able to communicate the critical elements of the system, and hold judgment about the quality of a colleague's performance. Simply having more experience as a principal does not make a person a suitable candidate to work with beginners. (Daresh \& Playko, 1989b, p. 95)

It may be not only necessary but advantageous to pair mentors and proteges from beyond district boundaries. In addition, it is important to establish collegial working relationships during the first year and to understand the limitations on power and control; administrators are not expected to know everything.

\section{SUMMARY}

The concept of mentorships as a training tool is not new but mentorships have emerged as a concept of significant interest concerning adult development and career 
development. It is commonly held that mentors may provide career and psychosocial benefits to the protege. Mentorships aid in the development of managerial talent and may revitalize older professionals who have an opportunity to share wisdom and expertise.

Mentor and protege relationships are seen by researchers to be complex and diverse. In mentoring relationships, the mentors set challenges, communicate expectations, counsel, provide feedback, and prepare the protege for promotion. Mentors must possess a wide knowledge of the organization to be effective and to be perceived as valid.

The concept of mentoring in educational administration may have evolved from the teacher induction process. As a result of the push for excellence, programs consisting of induction processes have become more prevalent in school districts, universities, and educational agencies.

Mentors and mentorship programs in educational administration have been developed much more slowly than programs that train teachers. It may be some time before administrative mentoring will have the same kind of clear descriptions that are increasingly influencing the inservice education of classroom teachers. Mentoring for administrators needs to place greater emphasis on the process skills that assist the individual with the transition from teacher to administrator. 
In conclusion, mentoring is based on a mutually-enhancing relationship. According to Daresh and Playko (1989a), it is important for the mentor to be:

knowledgeable about psychological and humanistic aspects of a relationship in order to create successful communication skills and listening skills, and to cultivate other abilities such as being honest, trustful, sincere, genuine, and sensitive. (p. 51)

The training of mentors must devote time to reinforcing the view that the mentor and protege are both participants of the mentoring "team." In order for the mentorship to be a positive one, the mentor needs to be available to offer assistance, guidance, and support to the aspirant or beginning administrator. Training must focus on the development and promotion of peer-to-peer relationships. The mentor needs to be aware that a mentorship is a significant commitment of time, effort, and energy, and that responsibility for success is shared by both the mentor and the protege. 
CHAPTER III

METHODS

GENERAL PLAN OF STUDY

This study, which was conducted with an administrative mentorship group within the oregon Mentorship Program, examined participants' perceptions and beliefs with respect to the program during their year of participation. The group of subjects included all participants in the Oregon Mentorship Program during the first four years of the program's existence. All participants were surveyed; participants included 77 school administrators serving as mentors and 79 administrative aspirants designated as proteges. Subsets of the total group were surveyed through personal interviews; their reactions, questions, and concerns related to their participation helped to form a basis for the questionnaire which was developed and administered. In addition, informal discussions with present and past program coordinators and program directors added insight and assisted in developing a historical perspective, an overview concerning the original intent of the program, and formulation of the questionnaire. Given the descriptive study format for this study, the general strategy followed in gathering and researching methodology 
in education according to Ary, Jacobs, and Razavieh (1985) is:

Descriptive: [which] 'Describes and interprets what is. [This form of inquiry] . . . is concerned with conditions or relationships that exist; practices that prevail; beliefs, points of view, or attitudes that are held; processes that are going on; effects that are being felt; or trends that are developing.' Its major purpose is to tell what is. (p. 26)

Ary et al. (1985) list several subcategories of descriptive research including case studies, surveys, developmental studies, follow-up studies, documentary analysis, trend studies, and correlation studies. This study was designed around the follow-up study model. The design allowed the researcher to describe and interpret activities, occurrences, beliefs, and perspectives which could be gained by retrospective examination.

The indicators used to arrive at descriptive data were those of the informal interviews, the focus groups, the pilot group, and the responses from the questionnaire. It should not be assumed that this study is an apologia for the Oregon Mentorship Program or any other specific program. However, as indicated in the literature review in Chapter II, it should be noted that mentorship programs are increasing in number in both the private and public sectors. Given this fact, the profession would do well to examine how the mentoring processes and mentorship program goals and activities met the needs and expectations of the participants and, at the same time, examine some of the life 
events of the subjects which may be associated with participation in the oregon Mentorship Program. It should also be noted that inferences of causality cannot be made with any degree of certainty due to the limitations of such a study. However, these findings may be able to be combined with findings from other administrative mentorship programs where trends will emerge from meta-analysis.

Comparisons within and between groups were made. The groups were divided by role in the program; practicing administrators served as mentors to aspirants; aspirants functioned as proteges under the sponsorship of the mentors. Response similarities and differences between these two groups were made as well as analysis of responses within the two groups.

\section{SUBJECTS}

The subjects for this study were all mentors and proteges who had taken part in the Mentorship Program during its first four years of existence, from the fall of 1986 through the spring of 1990. The subject group consisted of 77 mentors and 79 proteges; 2 mentors were deceased prior to the start of the research. Three mentors participated in the program twice as mentors and completed a questionnaire for each mentorship experience; they were, therefore, considered to be a subject for each mentorship year. No subject served as a protege and as a mentor during the first 
four years of the program. Cooperation was gained from the Confederation of Oregon School Administrators (COSA) to access lists of participants.

To qualify as a protege in the Mentorship Program: aspirants must hold an administrative certificate or be enrolled in a program leading to the certificate. Membership in COSA or NWEA is also desirable, but not required. (COSA Mentorship Program, 1990, p. 1)

One of the stated goals of the Mentorship Program was to "actively encourage members of under-represented groups to pursue administrative careers in education" (p. 1). Aspirants completed an application process and were selected on a basis of their "written statements, geographical distribution and career objectives" (p. 1). The application process included questions concerning immediate and long-range career goals, professional experiences leading to their interest in administration, expectations of the program, and how a mentor might assist them. Proteges were selected from a pool of aspirants by the Mentorship Coordinators; coordinators for the program consisted of the elected President of COSA, the Associate Executive Director of COSA, the cosA Project Director of the Mentorship Program, and one representative each from the Oregon Department of Education, Northwest Women in Educational Administration, Northwest Regional Educational Laboratory, and an institution of higher education in oregon with an Educational Administration Program. If selected, each 
protege was assessed one hundred dollars to offset program costs.

It should be noted that it does not seem possible to determine the exact criteria that were used for the selection of the mentors. The mentors did not participate in a formal application process but were selected by the Oregon Mentorship Program Coordinators. It must be assumed that the mentors were those seen to be effective administrators by colleagues both in and out of their districts.

During the years being studied, mentors numbered 39 males and 40 females; proteges numbered 21 males and 58 females. Table I illustrates gender of mentorship participants by year.

TABLE I GENDER OF MENTORSHIP PARTICIPANTS

\begin{tabular}{lrrrrr}
\hline & 1986 & 1987 & 1988 & 1989 & TOTAL \\
& 1987 & 1988 & 1989 & 1990 & \\
\hline Mentors & & & & & \\
MALE & 8 & 11 & 11 & 9 & 39 \\
FEMALE & 12 & 9 & 9 & 10 & 40 \\
Proteges & & & & & \\
MALE & 2 & 5 & 5 & 9 & 21 \\
FEMALE & 18 & 15 & 15 & 10 & 58 \\
\hline
\end{tabular}


As a point of reference for the reader, Table II illustrates the position title and gender of all oregon administrators in the 1989-1990 school year.

TABLE II

GENDER OF OREGON ADMINISTRATORS

1989-90 SCHOOL YEAR

\begin{tabular}{lcc}
\hline ADMINISTRATIVE POSITION & MALE & FEMALE \\
\hline Superintendents & 251 & 17 \\
Assistant Superintendents & 51 & 5 \\
Directors/Coordinators & 388 & 387 \\
Principals & 697 & 268 \\
Assistant Principals & 293 & 103 \\
Other: & 79 & 48 \\
Sptaff Development & & \\
$\begin{array}{l}\text { Supervisors, Discipline } \\
\text { Monitors, etc) }\end{array}$ & & \\
\hline
\end{tabular}

Tables III and IV illustrate the geographical locations, by region, of the mentors and proteges during the first four years of the program. As a point of reference for the reader, regions were generally determined to be: Metropolitan-Willamette Valley including the greater Portland area covering Beaverton, Tigard, Gresham, Lake Oswego, and Oregon City, as well as Salem, Corvallis, and Eugene areas. South State included Roseberg, Grants Pass, Ashland, Klamath Falls and Southern areas. East state 
encompassed Hood River, Pendleton, Bend, LaGrande, Baker, Ontario and all areas east of the Cascade Mountains. The Coast region was comprised of all Pacific coast towns west of the Coast Range, such as, Astoria, Seaside, Lincoln City and coos Bay.

TABLE III

GEOGRAPHY OF PARTICIPATING MENTORS

\begin{tabular}{ccccc}
\hline & $\begin{array}{c}\text { METRO } \\
\text { WILIAMETTE } \\
\text { VALLEY }\end{array}$ & $\begin{array}{c}\text { SOUTH } \\
\text { STATE }\end{array}$ & $\begin{array}{c}\text { EAST } \\
\text { STATE }\end{array}$ & COAST \\
\hline $1986-87$ & 16 & 1 & 3 & 0 \\
$1987-88$ & 17 & 2 & 1 & 0 \\
$1988-89$ & 17 & 2 & 1 & 0 \\
$1989-90$ & 19 & 0 & 0 & 0 \\
\hline
\end{tabular}

TABLE IV

GEOGRAPHY OF PARTICIPATING PROTEGES

\begin{tabular}{ccccc}
\hline & $\begin{array}{c}\text { METRO- } \\
\text { WILLAMETTE } \\
\text { VALLEY }\end{array}$ & $\begin{array}{c}\text { SOUTH } \\
\text { STATE }\end{array}$ & $\begin{array}{c}\text { EAST } \\
\text { STATE }\end{array}$ & COAST \\
\hline $1986-87$ & 14 & 1 & 5 & 0 \\
$1987-88$ & 17 & 2 & 1 & 0 \\
$1988-89$ & 7 & 2 & 1 & 0 \\
$1989-90$ & 19 & 0 & 0 & 0 \\
\hline
\end{tabular}

All participants had to agree to take part in a series of planned experiences. The participants were also supplied with suggestions of other, unplanned activities that the 
pairs might find professionally useful. There were four planned dinner meetings during each academic year of the program. Two of the meetings were planned to coincide with CosA conferences to which the proteges were invited free of charge. Because this was a state-wide program in a state that is sparsely populated outside of the Portland Metropolitan Willamette Valley area, the distance between mentor and protege sites was a variable that may not be found in other programs. In addition, the distance between the participant pairs and conference locations or dinner meetings needed to be taken into consideration. Because of similarities in design and planned activities, it was assumed that the program originators were familiar with the work of the Danforth Foundation concerning grant programs for mentorship experiences specifically targeted toward educational administrative aspirants. What was not known, however, was the degree to which the Danforth populations and the Oregon Mentorship Program participants were similar or different.

It was seen as important to survey as many respondents as possible. Much care was exercised to entice the respondents to reply to the survey instrument. To the degree that the total population's responses became part of the data set for later analysis, the conclusions and comments were more likely to reflect the program as lived in by the program participants. 
INSTRUMENT

A questionnaire format was selected as the best way to elicit information from the Oregon Mentorship Program participants regarding perceptions, structure, logistics, and relationships. Prior to constructing the self-administered questionnaire, research references were consulted (Ary et al., 1985; Campbell \& Stanley, 1963; Gay, 1987: Goetz Lecompte, 1984). In addition, a book by Fink and Kosecoff (1985) entitled How To conduct Surveys was utilized as the instrument was developed. Fink and Kosecoff state,

Survey purposes and methods fall on a continuum. Some surveys can have far-reaching, generalizable effects, and their methods must be scientific. others are conducted to meet very specific needs; their methods may not always achieve scientific rigor, but they must still be valid. (p.13)

Given that surveys are data collecting instruments, care needs to be taken in their construction. Because a sampling of a smaller number of participants may not produce sufficient quantities of data from which to draw conclusions, the universe of the set was included in this research design. The design can be characterized as a cross-sectional census design; it was also self-administered. Gay noted,

In a census survey, an attempt is made to acquire data from each and every member of a population; a census survey is usually conducted when a population is relatively small and readily accessible . . (p. 192) 
This study was a cross-sectional design as participants were surveyed just once; the design provided a portrait of things as they were at a single point in the continuum.

Initially, informal interviews were conducted with the present director of the Mentorship Program, the former director of the Program, one of the originators of the program idea and a member of Northwest Women In Educational Administration, a former mentor and presently an assistant professor in an educational administration program, and three former proteges to gather general background information and perceptions.

A focus group, consisting of three proteges and four mentors, was formed to give input concerning the initial information gathered and to assist in the design of questioning strategies. The focus group participants were selected on the basis of geographic proximity and willingness to give feedback to the researcher. A questionnaire draft was developed, comprised of questions gleaned from the informal interviews, focus group, research on effective mentoring, and the program design.

The questionnaire contained queries that have since been grouped as perceptions, structure, logistics, participant relationships, and demographic considerations dividing the instrument into three sections. Questions in the "perceptions" category asked the respondent to evaluate a program attribute or activity from his/her perspective 
(questions 2, 3,28, 29, and 30). The structure category asked respondents to evaluate specific activities or program components (questions $8,9,12,17,19,20,21,22$, and 23). Variables related to distance, geography and meeting frequency were combined as logistical (questions 6, 10, and 13). Participant relationships included questions 24, 25, 26, and 27 related to feedback, recommendations, job search, and a continued professional relationship (see Appendix A). Demographic questions germane to the study were included in Section III. Questions concerning gender, age, matching of temperament and personality, commitment, job satisfaction, net-working opportunities, and professional relationship were derived from the literature review and past research. Questions concerning geography, adequate time, flexible schedules, clarity of guidelines, goals, commitment as a professional, program design, planned activities, and job search assistance were generated by the focus group combined with input from the review of the literature. Open-ended questions were initiated to gain in-depth responses and allow freedom of expression. Additional comments were requested for a number of questions.

Two pilot groups were formed to elicit initial feedback on survey design and content. One group consisted of three proteges and the other group consisted of four mentors. Pilot group participants were selected on the basis of geographic proximity to the researcher. To make it 
user-friendly, directions were clear, concise, and in bold type; most responses could be completed by circling the appropriate number, filling in the blank with one, two, or three numbers, or by placing a check in the space provided. open-ended questions could be answered in just a few words. Spaces were provided for written responses and/or additional feedback. During pilot testing, clarity of the questions, general format, sufficient variety in the responses, and topic considerations were emphasized.

The final questionnaire was constructed with the intent to receive as much information as was necessary to draw conclusions on the perceptions of mentor and proteges with respect to the Oregon Mentorship Program (see Appendix A). Because the questionnaire was self-administered, care was taken to explain the purpose of the survey, including the aims and the participants. An offer to send the respondents a copy of the summary of results was made. A qualifying statement was included before the segment dealing with personal or demographic questions such as sex and age. In an attempt to make the procedure simple, a booklet format was selected for readability and ease in handling. Page breaks were carefully monitored so the respondent did not have to turn pages to complete rank-order questions. Layout provided ease in reading and room to respond. Although the questionnaire appeared lengthy at first glance, it was relatively simple to complete in approximately twenty 
minutes. A self-addressed, stamped envelope was provided for ease in returning the questionnaire to the researcher.

\section{PROCEDURES}

The questionnaire was designed to gather descriptive data. It was printed in booklet form, measuring 8.5 inches by 5.5 inches. The bright color of the cover, boldly printed title, and booklet form were selected to attract attention, and therefore, elicit greater response. The first item inside the questionnaire booklet was a letter, printed on the inside of the cover, to all participants explaining why each response to the survey was critical and important, to whom the questionnaire was being sent, the purpose of the survey, and assurances that the responses to the questionnaire would be held in confidence. Initial directions and section I questions began on the first page of the text.

Questions in Section I were nominal, ordinal, and ordinal interval in nature; the questions dealt with status with respect to the Mentorship Program. Likert-like scales were used to describe respondents' perceptions of the Mentorship Program, its value in promoting effective school administrators, factors concerning gender, personality, and age differences, and time to mentor or be mentored. Respondents were asked to respond to questions concerning the match between expectations at the outset of the program 
participation and at the end of their program activities. The remainder of the questions in section I consisted of nominal questions concerning site visitation, establishing year-long goals, and the frequency of contacts between mentor and protege pairs. Opportunities to explain briefly responses were provided for gender and age differential questions, time factor considerations, and goal setting. section II, the middle segment, contained ordinal interval questions about the programmatic structure and support of mentors or proteges with responses requested in Likert-like scales. Also contained in this section were nominal and ordinal questions in the areas of performance feedback, assistance in job searches and the writing of references, and continued association after program completion. Respondents were asked to rank order program attributes and program activities in terms of personal value in the mentoring program.

Section III, the final segment of the questionnaire, contained demographic information on professional status at the inception of their involvement with the program, highest level of education of participants, total number of years in education, their educational role during their year in the program, and participation in other formal or informal mentoring programs. Questions were asked concerning the number of years of experience at specific grade levels, and the student populations of their school and district. In 
addition, respondents were asked to identify their approximate age, ethnic background, and gender. The final question in this section dealt with personal and professional reasons for participating in the program; the question design was open-ended to encourage free-response. The last entry in the questionnaire was a request to return the completed questionnaire in a timely manner and a note of appreciation for their support and time. Although a stamped pre-addressed envelope was provided, the return address and phone number were reprintea at the end of the booklet. The final page was designated for "additional comments."

Participants were requested to return the questionnaire within a two week period. After three weeks, a reminder notice was sent to all participants who had not yet returned the survey. The final return rate was high with 71.48 of the mentors and $73 \%$ of the proteges responding.

\section{DATA ANALYSIS PROCEDURES}

During the time the questionnaire was being field tested and later completed by the Mentorship Program participants, the researcher constructed a SYSTAT file in which to enter data. The file was constructed so that fields could be altered or added before data entry began. Care was taken to make certain that the question types were 
paired with a suitable scaling system. As responses were received, each was entered into the data set on the statistical program. Initial decisions were being made on the statistical treatments most suitable for the data gathered. The chi-square test of significance, t-test, mean and standard deviation, Kendall's coefficient of concordance, and phi correlation coefficient were planned. In addition, frequency tables and other graphic representations were considered for inclusion. There was a desire to include both parametric and non-parametric statistical treatments.

Concerning the qualitative analysis for the questions with written responses, the researcher recognized that there are several methods to choose from and no clear guidelines for rigor as there are for quantitative research. Patton (1990) suggests that insight, creativity, and experience will play a major role when choosing a particular methodology to describe and analyze data, and that applying both quantitative and qualitative methods to a particular research question may be appropriate. Qualitative analysis has emerged as an important and essential means of research and program evaluation in many disciplines, not the least of which is education. Some proponents of either qualitative or quantitative research vehemently state that since these two forms of research have such different philosophical underpinnings, it is not possible to apply both to the same 
research question (Guba, 1978). Patton, whose theory is known as "phenomenology," classifies himself as a pragmatist and as such will apply both quantitative and qualitative methodology to a particular research question.

For the purpose of analyzing the open-ended questions on the mentorship survey, a combination of two qualitative methodologies was used. The first is known as phenomenology; simply stated, phenomenology is used to analyze the experiences of individuals in a program. It is used to get at the "essence" of their experience. The phenomenological approach makes "the assumption that there is an essence or essences to shared experience" (Patton, 1990, p. 70). These essences are the core meanings mutually understood through common experiences. The experiences of different people are "bracketed, analyzed, and compared to identify the essences of the phenomenon, for example, . . the essence of being a participant in a particular program" (Patton, 1990, p. 70).

According to Patton (1990):

In short, conducting a study with a phenomenological focus (i.e., getting at the essence of the experience of some phenomenon) is different from using phenomenology to philosophically justify the methods of qualitative inquiry as legitimate in social science research. Both contributions are important. But a phenomenological study (as opposed to a phenomenological perspective) is one that focuses on descriptions of what people experience and how it is that they experience what they experience. One can employ a general phenomenological perspective to elucidate the importance of using methods that capture people's experience of the world without conducting a 
phenomenological study that focuses on the essence of shared experience. . . (p. 71)

In conjunction with Patton's phenomenology, a method developed by Guba (1978) was used to find patterns and develop a category system for qualitative data analysis. Guba suggested that in focusing the analysis of qualitative data, the researcher must deal first with the problem of convergence, figuring out what things fit together, which leads to a classification system for the data. This methodology first seeks convergence in the data by building evidence for homogeneity within categories and heterogeneity amoung categories; secondly, divergence is sought by looking for patterns or categories within the data. This is accomplished by building on the items of information already known, making connections among different items, and proposing new information that ought to fit.

It is the researcher's belief that all methodologies have limitations and that in conjunction, appropriate quantitative and qualitative methodology can be a powerful approach to many research and evaluation problems.

The steps and procedures for qualitative data are not mechanical or rigid; the process of data analysis involves both technical and creative dimensions. The qualitative researcher's efforts at uncovering patterns, themes, and categories are creative processes that require making carefully considered judgments about what is really 
significant and meaningful in the data. Because qualitative researchers do not have statistical tests to tell them when an observation or pattern is significant, researchers must rely on their own intelligence, experience, and judgment (Patton, 1990). It is up to the researcher to choose a method or combination of methods specific to the task. (As an aside, the Federal government is presently requiring both approaches be used for certain program evaluations.) All respondents' responses appear unabridged in Appendices B and c. 
CHAPTER IV

\section{RESULTS}

Chapter IV contains a description of the results of the questionnaire directed toward gaining a full

understanding of the oregon Administrative program. As this dissertation was a descriptive and qualitative inquiry, the data were drawn from participants' responses to the questionnaire. However, these data also lend themselves to some kinds of quantitative analysis. The results of the statistical treatments follow in the remainder of this chapter. Amplification and interpretation of the results are included in chapter IV and discussed in Chapter $v$. For the purpose of analysis, the results were grouped into four categories; perception, structure, logistics, and participant relationships. Demographic data follows the categorized analyses. The perceptions category dealt with respondents' replies to questions with respect to their opinions of the mentorship itself. The structure section was concerned with how respondents viewed the organizational elements of the program. The logistics section was devoted to analysis of the execution of the program itself in areas dealing with concrete events which comprised the program. The final section was concerned with demographic data. 


\section{PERCEPTIONS}

In the first category, when respondents were asked to rate their year-long experience in the oregon Mentorship Program in a Likert-like scale from 1 to 5 , the number 1 represented "very satisfied," number 2 indicated "satisfied," number 3 signified "neutral," number 4 symbolized "dissatisfied," and number 5 elicited "very dissatisfied."

The total respondents numbered 112 with 55 mentors and 57 proteges included in the data set. Questions $2,3,28$, 29, and 30 asked for information regarding their perceptions of the mentorship program.

Question 2 "How would you rate your year-long experience in the (COSA) Oregon Mentorship Program?" was answered by all 112 respondents. The mean response for mentors was 1.909 compared to a mean response for proteges of 2.28. The standard deviation for mentors was 1.023 while that for proteges was 1.31. A t-test was conducted to determine if group differences existed between mentors and proteges in terms of how they rated their year-long experience. Nonsignificant differences were found with a $t=$ $1.439(\mathrm{df}=110, \mathrm{p}=0.15)$.

Question 3 concerned the program's value as it related to the process of preparing effective school administrators. The total respondents numbered 112 with 55 mentors and 57 proteges responding. The mean response for mentors was 
1.873 as compared to a mean response for proteges of 2.14 . The standard deviation for the mentors was 0.924 ; the standard deviation for the proteges was 1.008. A t-test was conducted to determine if group differences existed between mentors and proteges in terms of the program's value as it related to the process of preparing effective school administrators. Nonsignificant differences were found with $a t=1.466($ df $=110, p=0.146)$. Question 15 asked the respondents to rank order expectations and outcomes of their participation in the Mentorship Program. Mentors and proteges were not asked for the same information so the question was analyzed for mentors and for proteges independent of one another. Kendall's coefficient of concordance (w) was conducted to determine the concordance among the mentors for expectations as they began their year long participation in the program. Kendall's coefficient of concordance is a descriptive statistic (non-parametric) used to quantify the rank ordering of attributes from a sample. It ranges from zero to one; the closer it is to one, the more concordance (agreement) there is among the rankings within the context of the ordered groups. It is expressed as $W$ which is the quantitative expression describing the degree of concordance. By default, it is a descriptive rather than inferential statistic so no tests of significance are appropriate. The results showed a $w$ equal to 0.523 for 
mentors' expectations. Table $V$ was prepared to tabulate the results.

TABLE V

RANK ORDERING OF MENTOR EXPECTATIONS

FOR PROGRAM YEAR

\begin{tabular}{ll}
\hline EXPECTATION VARIABLE & RANK SUM \\
\hline Increase Professional Commitment & 136.0 \\
Increase Personal Satisfaction & 189.5 \\
Discuss Professional Issues & 218.0 \\
Establish Professional Network & 305.0 \\
Increase Professional Visibility & 434.0 \\
Improve Job Satisfaction & 323.0 \\
Increase Peer Recognition & 413.0 \\
Develop Managerial Talent of Protege & 152.0 \\
Create Energy and Propagate Expertise & 188.0 \\
Self Assessment as an Administrator & 336.0 \\
\hline
\end{tabular}

Mentors were asked in question 15 to rank order their perceptions of the outcomes as they related to the end of their year in the Mentorship Program. The lower the rank sum, the greater importance the respondents placed on the questionnaire item. Kendall's coefficient of concordance was conducted to determine the concordance among mentors. 
The results showed a $\mathrm{w}$ equal to 0.448 . Table VI shows the resulting data.

TABLE VI

RANK ORDERING OF MENTOR OUTCOMES

FOR PROGRAM YEAR

\begin{tabular}{ll}
\hline EXPECTATION VARIABLE & RANK SUM \\
\hline Increase Professional Commitment & 135.0 \\
Increase Personal Satisfaction & 141.0 \\
Discuss Professional Issues & 150.0 \\
Establish Professional Network & 266.0 \\
Increase Professional Visibility & 372.0 \\
Improve Job Satisfaction & 278.5 \\
Increase Peer Recognition & 340.5 \\
Develop Managerial Talent of Protege & 176.5 \\
Create Energy and Propagate Expertise & 186.5 \\
Self Assessment as an Administrator & 264.0 \\
\hline
\end{tabular}

Kendall's coefficient of concordance was conducted to determine the concordance among proteges regarding their expectations as they began the year long program. The results showed a $W$ equal to 0.272 . Table VII displays the responses.

Kendall's coefficient of concordance was conducted to determine the concordance among proteges regarding their 
perceptions of the outcomes as they ended their year in the Mentorship Program. The results showed a $w$ equal to 0.157 . Table VIII displays results.

TABLE VII

RANK ORDERING OF PROTEGE EXPECTATIONS

FOR PROGRAM YEAR

\begin{tabular}{ll}
\hline EXPECTATION VARIABLE & RANK SUM \\
\hline Gain Feedback Regarding Performance & 267.5 \\
Discuss Professional Issues & 205.0 \\
Establish Professional Network & 227.5 \\
Investigate Professional Issues & 220.0 \\
Evaluate Administration as a Career & 210.5 \\
Join Professional Organization & 329.0 \\
Learn About Other School Districts & 408.0 \\
Increase Professional Commitment & 258.0 \\
Assess Own Skills and Aptitudes & 381.5 \\
Self Assessment as an Administrator & 188.0
\end{tabular}

To reiterate, the Kendall's coefficient of concordance is a descriptive statistic; therefore, no tests of significance were conducted and thus no t-test, degrees of freedom, or probability scores could be reported. 
TABLE VIII

RANK ORDERING OF PROTEGE OUTCOMES FOR PROGRAM YEAR

\begin{tabular}{ll}
\hline OUTCOME VARIABLE & RANK SUM \\
\hline Gain Feedback Regarding Performance & 286.5 \\
Discuss Professional Issues & 191.5 \\
Establish Professional Network & 216.0 \\
Investigate Professional Issues & 198.0 \\
Evaluate Administration as a Career & 270.0 \\
Join Professional organization & 293.0 \\
Learn About Other School Districts & 338.5 \\
Increase Professional Commitment & 182.0 \\
Assess Own Skills and Aptitudes & 313.5 \\
Self Assessment as an Administrator & 241.0 \\
\hline
\end{tabular}

The results of questions $15 \mathrm{~A}$ and $15 \mathrm{~B}$ concerning the mentor and protege expectations and outcomes of the yearlong Mentorship Program showed moderate concordance for the mentors and low concordance for the proteges. Question $15 \mathrm{~A}$ showed fairly high $(W=0.523)$ concordance concerning rank order of expectations and fairly high $(w=0.448)$ for outcomes for the mentors. Question 15B showed low concordance for rank ordering of expectations $(w=0.272)$ and low concordance for rank ordering of expectations 
$(W=0.157)$ for proteges. There was no statistical

treatment to compare data from expectations and outcomes. Because different variables were asked the mentors and proteges, comparisons between groups would be inappropriate. In addition, the question format may have been confusing; 49 mentors responded to 15A expectations; 42 mentors responded to $15 \mathrm{~A}$ outcomes; 49 proteges responded to 15B expectations, 46 proteges responded to $15 \mathrm{~B}$ outcomes.

Question 28 asked the participants to rate whether or not the program expectations met their perceptions when they began the year-long experience. A chi-square test was conducted to determine if the responses of the mentors and proteges were related to one another. Nonsignificant differences were found with a $x^{2}=0.643$ (df $=1$, $p=0.423)$. The phi-correlation coefficient was applied to supplement the findings with the chi-square test. The phicorrelation coefficient was -0.076 . Since the results from both statistical treatments corroborate one another, it may be stated that no association or relationship existed between the participant variable and the experienceperception variable.

In question 29, participants were asked to respond regarding their perceptions of various attributes of any mentorship program. The participants were asked to note their view of the importance of specific mentorship program attributes. Attributes selected were mentorship training, 
the selection process for mentors and proteges, clarity of mentorship program requirements, support for program activities, time to meet the needs and requirements of the program, a selection process which ultimately matched mentors with proteges, meetings held (both scheduled and informal meetings), views of the participants regarding the support provided as a serendipitous outcome of the program, function of participants as support people within pairs, and a goal-setting process.

Kendall's coefficient of concordance was conducted to determine the concordance among the respondents as a whole and within each of the groups. The results showed a $\mathrm{w}$ equal to $0.192,0.216$, and 0.204 for the group as a whole, proteges, and mentors, respectively. Table IX tabulates the rank ordering.

With an $n$ of 108 and groups of 52 mentors and 56 proteges responding, Kendall's coefficient of concordance did not yield data that would differentiate the groups. The Kendall's coefficient of concordance for both groups in the study was relatively small. It was reasonable to state that this statistical treatment did not yield substantively significant results for purposes of this investigation regarding the efficacy of particular program attributes. 
TABLE IX

RANK ORDERING OF ATTRIBUTES FOR

SUCCESSFUL MENTORSHIP PROGRAMS

\begin{tabular}{|c|c|c|c|}
\hline & $\begin{array}{c}\text { ALL } \\
\text { Rank Sum } \\
\end{array}$ & $\begin{array}{l}\text { PROTEGES } \\
\text { Rank Sum } \\
\end{array}$ & $\begin{array}{l}\text { MENTORS } \\
\text { Rank Sum } \\
\end{array}$ \\
\hline Mentorship Training & 679.0 & 335.5 & 343.5 \\
\hline $\begin{array}{l}\text { Selection Process for } \\
\text { Proteges }\end{array}$ & 697.5 & 412.5 & 285.0 \\
\hline Program Requirements & 592.0 & 321.5 & 270.5 \\
\hline Support of Employer & 520.0 & 242.5 & 278.0 \\
\hline Availability of Time & 364.0 & 201.0 & 163.0 \\
\hline $\begin{array}{l}\text { Selection Process for } \\
\text { Mentors }\end{array}$ & 726.5 & 377.5 & 349.0 \\
\hline Mandatory Meetings & 694.0 & 358.5 & 335.5 \\
\hline $\begin{array}{l}\text { Existence of Informal } \\
\text { Support Group }\end{array}$ & 778.5 & 385.5 & 393.0 \\
\hline $\begin{array}{l}\text { Availability of } \\
\text { Mentor/Protege for } \\
\text { Contacts }\end{array}$ & 414.0 & 210.0 & 204.0 \\
\hline $\begin{array}{l}\text { Establishing Year Long } \\
\text { Goals }\end{array}$ & 474.0 & 235.5 & 238.5 \\
\hline $\begin{array}{l}n= \\
\text { Kendall's Coefficient of } \\
\text { Concordance }(W)=\end{array}$ & $\begin{array}{r}108 \\
0.192 \\
\end{array}$ & $\begin{array}{r}56 \\
0.216 \\
\end{array}$ & $\begin{array}{r}52 \\
0.204 \\
\end{array}$ \\
\hline
\end{tabular}

When the researcher examined the activities that were central to the goals of the oregon Mentorship Program, a somewhat different picture emerged. Question 30 asked the respondents to rank order the relative importance of selected program activities central to the program. Those selected for statistical treatment were COSA meetings, selfscheduled meetings, informal contacts, networking, time 
spent between the pair, opportunity for analysis of personal strengths and weaknesses, social events, mutual goal setting, and the question of service to the profession on the part of both mentors and proteges. Table $X$ visually details the rank ordering of activities by perception of value.

TABLE X

RANK ORDERING OF ACTIVITIES BY PERCEPTION OF VALUE TO OREGON MENTORSHIP PROGRAM

\begin{tabular}{|c|c|c|c|}
\hline & $\begin{array}{c}\text { ALL } \\
\text { Rank Sum } \\
\end{array}$ & $\begin{array}{l}\text { PROTEGES } \\
\text { Rank Sum } \\
\end{array}$ & $\begin{array}{l}\text { MENTORS } \\
\text { Rank Sum }\end{array}$ \\
\hline CosA Meetings & 582.0 & 314.0 & 268.0 \\
\hline $\begin{array}{l}\text { Self Scheduled Meetings } \\
\text { With Mentor/Protege }\end{array}$ & 287.0 & 145.5 & 141.5 \\
\hline $\begin{array}{l}\text { Informal Contacts with } \\
\text { Mentor/Protege }\end{array}$ & 425.5 & 224.0 & 201.5 \\
\hline $\begin{array}{l}\text { Professional Networking } \\
\text { Activities }\end{array}$ & 606.0 & 291,5 & 314.5 \\
\hline $\begin{array}{l}\text { Spending Time with } \\
\text { Mentor/Protege }\end{array}$ & 286.5 & 143.5 & 143.5 \\
\hline $\begin{array}{l}\text { Opportunity for Analysis } \\
\text { of Personal strengths } \\
\text { and Weaknesses }\end{array}$ & 587.0 & 296.0 & 291.0 \\
\hline $\begin{array}{l}\text { Social Hour Prior to } \\
\text { Meetings }\end{array}$ & 824.5 & 392.5 & 432.0 \\
\hline Mutual Goal Setting & 510.5 & 280.5 & 230.5 \\
\hline Professional Service & 751.0 & 393.5 & 357.5 \\
\hline $\begin{array}{l}\mathrm{n}= \\
\text { Kendall's Coefficient of } \\
\quad \text { Concordance }(w)=\end{array}$ & $\begin{array}{r}108 \\
0.394\end{array}$ & $\begin{array}{c}56 \\
0.411\end{array}$ & $\begin{array}{r}52 \\
0.389\end{array}$ \\
\hline
\end{tabular}


Kendall's coefficient of concordance was conducted to determine the concordance among the respondents as a whole and within each of the groups. The results showed $a \mathrm{w}$ equal to $0.394,0.411$, and 0.389 for the group as a whole, proteges, and mentors, respectively. The results suggested moderate concordance regarding the rank ordering of activities as previously noted. Table $X$ displays the tabulation.

\section{STRUCTURE}

As noted earlier, the structure section concerned those reactions of participants to the organization or structural elements of the mentorship program.

The variable of time as a factor in providing a quality mentorship experience was explored in question 8 with both groups. A t-test was conducted to determine if group differences existed between mentors and proteges in terms of how they rated access to adequate time as a factor in providing a rewarding and significant mentoring experience for the mentor/protege. Nonsignificant differences were found with a $t=-0.585$ (df $=108$, $p=0.56)$.

In response to question number 9 concerning the clarity of the proposed experience and its effect on the establishment of an effective mentoring relationship, a 
t-test was conducted to deterwine if directives and guidelines were stated with enough clarity for participants to establish effective relationships. Significant differences were found with a $t=1.962$ (df $=109$, $p=0.05)$. Table XI summarizes these results.

TABLE XI STATISTICAL ANALYSIS OF SURVEY QUESTION 9

\begin{tabular}{cccc}
\hline & $\mathrm{n}$ & $\overline{\mathrm{x}}$ & $\mathrm{SD}$ \\
\hline MENTOR & 55 & 2.000 & 0.839 \\
PROTEGE & 56 & 2.375 & 1.153 \\
$\mathrm{t}=-1.962$ & $\mathrm{df}=109$ & $\mathrm{p}=0.05$ \\
\hline
\end{tabular}

Question 12 asked all participants if a year-long goal was developed. A chi-square test was conducted to determine if the responses of the mentors and proteges were related to one another. Significant differences were found with a $x^{2}=4.525(\mathrm{df}=1, p=0.03)$. A follow up with the phicorrelation coefficient indicated a moderately negative relationship between the participant variable and their perceptions of the development of year long goals $(\Phi=-0.202)$. The data analysis is presented in Table XII. 
TABLE XII

STATISTICAL ANALYSIS OF QUESTION 12

\begin{tabular}{|c|c|c|c|}
\hline & MENTORS & PROTEGE & TOTAL \\
\hline No & 15 & 38 & 42 \\
\hline YES & 39 & 30 & 69 \\
\hline$x^{2}=4.525$ & $\begin{array}{l}54 \\
d f\end{array}=1$ & 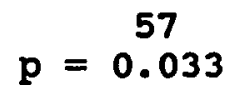 & $\Phi \stackrel{111}{=}-0.202$ \\
\hline
\end{tabular}

Question 17, queried the informal structural elements of the Oregon Mentorship Program and its relationship to a positive response to the program was analyzed. A t-test was conducted to determine if group differences existed between mentors and proteges in terms of the informal structural elements. Nonsignificant differences were found with a $t=0.731(d f=109, p=0.466)$.

Question 19 asked respondents to reflect on the four CosA-planned dinner meetings in terms of their importance to the mentorship program. A t-test was conducted to determine if group differences existed between mentors and proteges in terms of how they rated their participation in $\cos A$ dinner meetings. Nonsignificant findings were found with a $t=-0.731(\mathrm{df}=109, \mathrm{p}=0.46)$.

With respect to other means of contact between mentors and proteges, question 20 asked respondents to rate the importance of telephone conversations throughout the 
mentorship year. A t-test was conducted to determine if group differences existed between mentors and proteges in terms of how they rated telephone contacts. Nonsignificant differences were found with a $t=-0.945$ (df $=109$, $p=0.347)$

Question 21 gathered data concerning face-to-face, non-cosa planned meetings as a means of communicating. Nonsignificant differences were found between mentors and proteges concerning the importance of informal meetings. A t-test was conducted to determine if group differences existed between mentors and proteges in terms of how they rated informal meetings. Nonsignificant differences were found with a $t=1.452$ (df $=109, p=0.150$ ).

The participants were asked in question 22 if attending conferences and workshops with their mentor/protege served as important learning opportunities for those taking part in these activities. A t-test was conducted to determine if group differences existed between mentors and proteges in terms of how they rated joint participation in conference attendance as a learning activity. Nonsignificant differences were found with a $t=-0.067(\mathrm{df}=104, p=0.947)$

With respect to question 23 , mentors and proteges were asked to rate the value of site visitations. A t-test was conducted to determine if group differences existed between 
mentors and proteges in terms of how they rated site visitations. Significant differences were found with a $t=2.568(\mathrm{df}=109, p=0.012)$. Results are summarized in Table XIII.

TABLE XIII

STATISTICAL ANALYSIS OF SURVEY QUESTION 23

\begin{tabular}{llll}
\hline & $\mathrm{n}$ & $\overline{\mathrm{x}}$ & $\mathrm{SD}$ \\
\hline MENTOR & 55 & 2.036 & 1.186 \\
PROTEGE & 56 & 1.500 & 1.009 \\
$\mathrm{t}=-2.568$ & $\mathrm{df}=109$ & $\mathrm{p}=0.012$ \\
\hline
\end{tabular}

LOGISTICS

The respondents were asked in question 6 if distance from one another was a negative factor in the mentoring experience. $t$-test was conducted to determine if group differences existed between mentors and proteges in terms of how they rated geographic distance between mentor and protege as a factor in the mentoring experience. Nonsignificant differences were found with a $t=0.457$ $(d f=108, p=0.648)$.

Respondents were queried in question 10 concerning whether or not visits to each other's sites were held between the mentorship pairs. The results of the question may have value since a visit by the protege to the mentor's 
site might be expected within the program but reciprocal visits by the mentor to the proteges's site might not be so common. Protege visits to mentor sites could be expected to allow the protege to observe, analyze, and assess the mentor's management techniques and leadership styles. visits to mentor sites could encourage the protege to refine skills under the supervision of the mentor and broaden his/her exposure to a variety of building organizational plans.

Mentor visitations to protege sites were less common but may still have equal importance. A mentor's visit to a protege's site may provide evidence of interest and commitment to that protege. The mentor may learn about the skills and previous experiences of the protege. The protege could demonstrate to the mentor what he/she already knows and can do well. The mentor could observe the protege in action and in interaction with the current staff. The visit could also give the protege the opportunity to showcase his/her involvement in a statewide program to develop and improve leadership skills. Mentor visits to protege sites may improve protege self esteem and status. A chi-square test, comparing dichotomous responses, was conducted to determine if the responses of the mentors and proteges were related to one another. Significant differences were found with a $x^{2}=39.576(\mathrm{df}=1, \mathrm{p}=0.00)$. The phi-correlation coefficient was 0.594 , suggesting a fairly high degree of 
association between these two variables. Table XIV delineates the analysis of questionnaire responses.

TABLE XIV

STATISTICAL ANALYSIS OF QUESTION 10

\begin{tabular}{|c|c|c|c|}
\hline & MENTOR & PROTEGE & TOTAL \\
\hline No & 17 & 38 & 55 \\
\hline YES & 21 & 34 & 55 \\
\hline$x^{2}=0.6443$ & $\begin{array}{l}38 \\
d f=1\end{array}$ & $p=-\begin{array}{c}72 \\
-.423\end{array}$ & $\Phi=-0.76$ \\
\hline
\end{tabular}

PARTICIPANT RELATIONSHIPS

Questions $24,25,26$, and 27 were categorized under the general heading of participant relationships. With respect to question 24 regarding the provision of specific and concrete feedback about performance, a chi-square test was conducted to determine if the responses of the mentors and proteges were related to one another. Nonsignificant differences were found with a $x^{2}=2.074$ (df $=1$, $\mathbf{p}=0.210)$.

Question 25 asked program participants if assistance was provided regarding job searches or position changes. A chi-square test was conducted to determine if the responses of the mentors and proteges were related to one another. 
Nonsignificant differences were found with a $\chi^{2}=0.605$, $(d f=1, p=0.437)$.

Question 26 asked if there were requests between the mentor protege pairs for letters of recommendation.

A chi-square test was conducted to determine if the responses of the mentors and proteges were related to one another. Nonsignificant differences were found with a $x^{2}=0.374,(d f=1, p=0.541)$.

The final question, number 27 , in this series probed for information as to the continued existence of professional relationships after the year spent in the Oregon Mentorship Program. A chi-square test was conducted to determine if the responses of the mentors and proteges were related to one another. Nonsignificant differences were found with a $\chi^{2}=0.037,(d f=1, p=0.848)$.

\section{DEMOGRAPHICS}

Demographic questions concerning age, gender, professional status, ethnicity, geography, participation in other mentorship programs, and school or school district size were asked to gather data.

Results of question 31 that asked for the professional status of the participant during the mentorship year and question 32 that asked for the current professional status were virtually identical for the mentors. There had been no change in their professional status from the time of 
mentorship to the time of survey response. However, some changes had taken place for the proteges. Those results are summarized in Table XV.

TABLE XV

PROFESSIONAL STATUS OF PROTEGES DURING MENTORSHIP

AND AT TIME OF RESPONSE TO SURVEY

\begin{tabular}{lcc}
\hline & $\begin{array}{c}\text { STATUS } \\
\text { DURING } \\
\text { MENTORSHIP } \\
\text { n }\end{array}$ & $\begin{array}{c}\text { CURRENT } \\
\text { STATUS } \\
\text { n }\end{array}$ \\
\hline $\begin{array}{l}\text { Graduate student } \\
\text { Teacher }\end{array}$ & 3 & 0 \\
$\begin{array}{l}\text { Special } \\
\text { Education } \\
\text { Coordinator }\end{array}$ & 45 & 25 \\
$\begin{array}{l}\text { Counselor } \\
\text { Media Specialist }\end{array}$ & 3 & 2 \\
$\begin{array}{l}\text { Administrative } \\
\text { Intern }\end{array}$ & 0 & 0 \\
$\begin{array}{l}\text { Assistant } \\
\text { Principal }\end{array}$ & 1 & 2 \\
Principal & 0 & 1 \\
$\begin{array}{l}\text { Personnel } \\
\text { Director }\end{array}$ & 0 & 3 \\
Superintendent & 0 & 0 \\
Other & 0 & 0 \\
\hline
\end{tabular}

Question 32, part $c$, asked respondents for their longevity in their current position. Question 35 asked for 
the total number of years the respondent had been an educator. The results are tabulated for comparison in Table XVI.

TABLE XVI

MEAN YEARS EXPERIENCE AS AN EDUCATOR AND MEAN NUMBER OF YEARS IN CURRENT POSITION

\begin{tabular}{lcc}
\hline & Proteges & Mentors \\
\hline Mean Years as an Educator & 17.8 & 21.7 \\
Mean Years in Current Position & 3.9 & 5.7 \\
\hline
\end{tabular}

Proteges and mentors were asked to report the highest degree attained. The degree programs were grouped for convenience in data entry: $\mathrm{BS} / \mathrm{BA}$ and MA/MAT/MS were recorded together, enrollment in an administrative program constituted the second category. Attainment of an administrative certificate, enrollment in a doctoral program, and PhD/EdD were the other three categories. Responses are summarized in Table XVII.

Question 40 asked respondents to categorize their ages. Predictably, more mentors were categorized in the older age categories. Age comparisons are summarized in Table XVIII (AGE OF RESPONDENTS). 
TABLE XVII

HIGHEST DEGREE ATTAINED BY SURVEY RESPONDENTS

\begin{tabular}{lcc}
\hline & MENTORS & PROTEGES \\
\hline BS/BA MA/MAT/MS & 20 & 14 \\
$\begin{array}{l}\text { Enrollment in an } \\
\text { Administrative Program }\end{array}$ & 1 & 1 \\
$\begin{array}{l}\text { Administrative } \\
\text { Certificate } \\
\text { Enrollment: PhD }\end{array}$ & 13 & 30 \\
PhD/EdD & 4 & 6 \\
\hline
\end{tabular}

TABLE XVIII

AGE OF RESPONDENTS

\begin{tabular}{lrrrrrrr}
\hline & AGE & AGE & AGE & AGE & AGE & AGE & \\
& 30 & 35 & 40 & 45 & 50 & 55 & \\
& to & to & to & to & to & to & Total \\
& 34 & 39 & 44 & 49 & 54 & 59 & \\
\hline PROTEGE & 4 & 7 & 20 & 19 & 5 & & 57 \\
& & & & & & & \\
MENTOR & 2 & 4 & 12 & 55 & 12 & 3 & 55 \\
\hline
\end{tabular}

one of the stated goals of the Mentorship Program was to serve under-represented groups. The ethnicity of respondents was an important consideration since this data might help evaluate the attainment of that priority. Table XIX enumerates the ethnicity of respondents. 
TABLE XIX

ETHNICITY OF RESPONDENTS

\begin{tabular}{lcc}
\hline & PROTEGE & MENTOR \\
\hline No Response & 2 & \\
Native American & 1 & \\
Asian American & 2 & 1 \\
African American & 1 & \\
Hispanic & 2 & \\
Caucasian/White & 49 & 54 \\
Total Respondents & 57 & 55 \\
\hline
\end{tabular}

Gender of respondents was solicited in question 43 . The survey results show a preponderance of female participants though mentors were almost evenly distributed by gender. Table $\mathrm{Xx}$ displays the distribution of participants by gender.

The size of school populations was requested in question 45. The data are reported as means of the school populations as estimated by the respondents. The estimated school population for mentors was 585.7 students; the estimated school populations for proteges was 734.8 students for proteges.

In addition to the statistical approach to reporting quantitative data, qualitative analysis of the written responses follows. 
Question 4A or 4B: Was the fact that your mentor/protege was the same gender helpful (4A)? Opposite gender helpful (4B)? Categories for the written responses to these questions were defined as follows: no difference; difference helpful; difference not helpful; conditional; poor mentor. Information from 4A was separated from 4B. The adequacy of the classification system can in part be determined by the number of cases which fall outside or between the categories. In this instance, only two fell outside; those stating that their mentors were basically poor mentors and really did not want to mentor. This necessitated the creation of the category called "poor mentor."

The quantitative data from questions $4 \mathrm{~A}$ and $4 \mathrm{~B}$ concerning same gender and cross gender mentor/protege pairing were not reliable. A significant number of respondents completed both questions when the directions requested that respondents select either $4 \mathrm{~A}$ or $4 \mathrm{~B}$ depending on the gender of their pairing. Thirty-two mentors responded with a written explanation to question $4 \mathrm{~A}$ or $4 \mathrm{~B}$. Twenty-seven said that gender did not matter. clearly, greater numbers of mentors than proteges felt this to be so, although it was a majority for both groups. Two felt that the same gender was helpful, one is clearly a woman. Two responses did not fit the question being asked. One was a conditional "yes" to same gender by stating the following: 
Unfortunately, I believe there still exist some men who believe that they have little to learn from women. I think an older-ish man with a younger woman would be a poor match.

Only 28 proteges responded to question $4 A$ or $4 B$ with a written response. Of those 28,11 thought that gender difference was irrelevant. These 11 answered question 4A. Fourteen answered the same way but for 4B. Two proteges felt that having the same gender as a mentor was helpful. Both of these proteges were women and they felt that the insights and perspectives their mentors had as women were unique and essential. Three proteges were ambivalent as to whether or not having a mentor of the same gender was helpful. One protege felt that a mentor of the opposite gender might be helpful. This person was not sure, however, since all previous mentors this person had had were of the same gender.

In general, more women than men felt that having a mentor of the same gender was helpful. Although, it was not clear whether these women had a male with whom to compare experiences. Overall, most respondents felt that the issue of having a mentor of the same gender was irrelevant.

One person was rather philosophical about this issue and used a metaphor to communicate as follows: "Leadership qualities, skills, experiences, and what you put into the program 'sees' no gender." Other representative mentor responses follow. "There was comfort in meeting in restaurants, in my home and other places without concern of 
male/female relationship." "I do not strongly identify gender issues related to current expectations of administrative leaders." "Quality of the candidate, not the gender is the important factor for me." Appendix B completely lists all mentors' responses to questions $4 \mathrm{~A}$ and 4B.

Proteges responded similarly. "I have since worked with a male mentor and his advice and our professional relationship has been even better than my COSA mentor's. (which makes me think gender is not an issue)." "Really doesn't matter--it's the experience shared--Gender is for sexists." "Gender does not determine a successful, dynamic educational leader who is able to build an excellent school." See Appendix c for complete reproduction of protege responses to questions $4 \mathrm{~A}$ and $4 \mathrm{~B}$.

Question 7A or 7B: Was age difference a negative factor in your mentoring relationship (7A)? Positive (7B)? The quantitative data yielded unreliable data as respondents completed both questions when the directions requested that respondents select either $7 \mathrm{~A}$ or $7 \mathrm{~B}$. Since the written portion of this question was optional, few mentors or proteges chose to respond. The categories developed were as follows: age irrelevant; age close is better; age far apart is better; conditional; no difference in age.

Twenty-four mentors responded to the written portion of question 7A or 7B. Twenty of the respondents stated that 
age was not a factor. Three were close in age and did not respond to the negative or positive aspect of the question on that basis, and one mentor was older and stated that the difference was beneficial.

Twenty-two proteges responded to the written portion of this question. of those, 15 stated that age was irrelevant. Two felt that similar age matching between the mentor and protege seemed to be optimal. Respondents stated that similar stages and experiences in life seemed to bode well for the relationship. One felt that age far apart was more appropriate with the mentor being older. An older mentor to this respondent meant that this mentor would have more experiences and insights to share. Five respondents stated that there was no age difference and decided not to respond to $7 \mathrm{~A}$ or $7 \mathrm{~B}$ on that basis.

Most mentors and proteges felt that age made little difference in the mentoring relationship. A minority of proteges felt similar age was important. One mentor and one protege felt that an older mentor was most beneficial since the mentor would have more experience and insight.

Question 8: Was adequate time a factor in providing a rewarding and significant mentoring experience for your mentor/protege? The following categories were used: enough time; not enough because of schedule; not enough time because of distance; not enough time because of lack of commitment; does not fit. 
Thirty-one mentors chose to respond to this question. Twelve, 14, 2, 3, and 1 responded to the above categories, respectively. For those who felt there was adequate time, flexible schedule and commitment to make time were important. Schedules were a critical factor in limiting the time together. Distance was a small factor since only two mentors responded to this category. All 57 proteges responded to this question. Many felt that there was adequate time (28). Twenty-two felt that schedules did not permit enough time together. Distance was a factor for three proteges. A lack of commitment was a factor for five proteges. Two responses did not fit the categories. The proportion of responses in each category for proteges was approximately the same for mentors, even though fewer mentors responded than proteges. This is valid evidence for both groups' reasons for the choices made regarding time.

Question 11: Did you have release time or a flexible schedule to participate in visitations? Categories developed are as follows: no release or flex time; flexible schedule; release time; after hours; personal leave. Only 21 mentors responded to this question. Many had flexible schedules (15). Many of these were principals. No mentor took release time. The remainder met after hours. Thirtyone proteges responded and seemed to be fairly evenly distributed across the five categories. Some had supportive supervisors and districts that allowed them flexible 
schedules or release time for visitations. Those who did not have flexible time, chose to take personal leave for visitations, making a commitment to the mentorship process. Question 12: Did you and your mentor/protege develop a year-long goal? The categories included only "Yes" and "No." Most mentors stated that goals were set (29). Only three said no. Those goals ranged from developing a resume, to observing several administrative settings, to getting a job. A majority of proteges also stated that goals were set (24). Five said that no goal was set. The distribution of yes and no responses was similar between the two groups. This validated the survey and the category system of analysis.

Question 32: Are you aspiring to another job? Categories established included: "Yes," "No," "Undecided." of the 11 mentors who responded, nine were seeking other positions. All 15 proteges who responded wanted another position. Many sought a position in the central office or a principalship. The sample of the total respondents ( $n$ ) was small. No qualitative analysis was conducted.

Question 38: Did you have or have you had an informal mentor or sponsor in your career? Categories were "Yes," "No." Most mentors and proteges have had mentors. They came from all parts of the education spectrum. Mentors responses indicated both formal and informal mentorships. "Lots of peers, former bosses and colleagues with whom I 
share and on whom I rely." "Just my husband--an excellent mentor." "Various administrators have assisted me with advice and/or formal recommendations when requested." "In a district program." See Appendix B for a complete listing of responses. Proteges responses were comparable. "Past employers are very helpful." "A former principal of mine has been an informal mentor over the years."

This year I am participating in an informal administrative intern opportunity. I am receiving a stipend to direct the Beginning Teacher support Program in our district. I've also [been] invited to a series of administrative inservice workshops offered to district administrators. My assistant superintendent has been a source of support this year.

Question 46: Why do you think you were selected for the program? Categories had to be established separately for mentors and proteges. Categories for mentors included: do not know; interest in mentoring; experience, background, style; I was known; no fit. Forty-two mentors chose to respond. Nine were not sure why they were chosen; two felt that their interest was the main factor for selection. Thirteen felt that their experience, background, and administrative style were the determining factors for selection while 14 felt that they had been chosen simply because they were known in the area. Three responses did not fit into categories and made little sense given the question.

Proteges were categorized as: do not know; desire, or commitment; qualifications; woman, or minority. Thirty-four 
proteges chose to respond to this question. Only three did not know why they were chosen compared to nine mentors who did not know. Eight felt that their desire was the determining factor in their selection. Most (19) felt that their qualifications made them a clear choice for selection. Some of these felt that their letter of application got them in. Four felt that being a woman or minority was the reason for their selection.

The following are representative mentor responses. "Interest in mentor in mentor program. Previous experience with assessment center and Springfield simulation."

I have a strong interest in developing future administrators, I am interested in personnel aspects of administration (resume writing, interviewing), and I am interested in growing as an administrator.

"Because of my background and interest in helping new administrators." "Those who selected mentors knew me and my work." "Someone in the COSA/NWEA office knew me." "It's hard to say 'no' to someone you respect..." "I was honored to be asked and I thought I would learn a lot from participating. I was right!" " .. I feel a professional commitment to help others as I was helped."

Proteges were also very responsive. "Geographic concerns and good application." "Because I was persistent in applying to the program for 3 years before being accepted." "I applied, was female, and it was the first year. Maybe I write well or they could see the tears on the application." "I was recommended by our superintendent." 
"Ethnicity . . ." "I was and am serving in leadership positions at the building, district and county level. I hold an administrative certificate and am interested in a career change." "Because I am a female with a broad range of experiences and interests."

Question 47: If you were a protege, you applied and were selected to participate; if you were a mentor, you were asked to participate by the coordinating committee. What were your personal or professional reasons for participating? Response categories were different for mentors and proteges.

Mentor categories were: to help/pay back; had something to offer; was asked; grow professionally. Fortyfour mentors responded to this question. Nineteen felt that helping others into the profession or to pay back to others what was done for them was the main reason for participating as a mentor. Five mentors felt that they had skills and experience to offer others and therefore, decided to participate. Eight mentors were asked and either felt so flattered or committed to participate after being asked that they became mentors. Nine people felt that they participated because they would grow professionally or that they had a professional obligation to do so.

proteges were analyzed using the following categories: viable method to enter the profession; wanted guidance from a mentor for professional growth; wanted to observe and work 
with an administrator in order to decide whether or not to become an administrator. Fifty-one proteges responded to this question. Forty felt that by participating this would lead to a job change. Some responses spoke of "rumors" from past mentorship years in which $50 \%$ of the participants were placed into administrative positions. Four participated simply for the guidance a mentor could bring and, therefore, grow professionally. Seven participated to observe and work with an administrator to help them decide on whether or not to pursue an administrative position.

Sample mentor responses follow.

I personally appreciate time colleagues spent with me over the years. Professionally, I feel I have an obligation to promote growth and development.

"I was interested in helping out an aspiring administrator reach his or her goal as a principal. I was also interested in sharing my experiences as an administrator." "I felt honored and validated by being asked. . . . I wanted to reciprocate." "To help develop instructional leaders." "I believe education needs good administrative leaders. It is my hope and desire to be able to work with individuals who are excited about education and working with young people." "What goes around comes around. I'm in education to help people . . ." "NWEA was very important to me during my first years as administrator . . . I wanted to provide that for someone myself." "Hoped it would be growth producing 
for myself." (See Appendix B for complete reproduction of written responses.)

Proteges expressed desires to improve and change jobs. ". . I felt I was at a standstill in my career, and this experience gave me a 'push' and kept me current." "I really hoped this would offer opportunities to make myself known outside my district . . ." "I wanted practical experience to help me decide if I really wanted to be an administrator." "It was a perfect opportunity to do a practicum without leaving my current job." "I was hoping to gain an understanding of the role of principal--the kinds of things you might not learn in a classroom." "This program was a formal manifestation of an informal system I had tried to build for myself." "Advancement, experience, networking." "Desire for advancement from teaching to administration." "I was told about $50 \%$ of the previous people enrolled had been given job offers." (See Appendix c for a complete compilation of protege written responses.) 
CHAPTER V

SUMMARY AND RECOMMENDATIONS

\section{INTRODUCTION}

This study was a descriptive study of the oregon Mentorship Program. The purpose of the study was to conduct an jn-depth analysis of the program as a process which was aimed toward the global goal of improvement of instruction. The study consisted of four components; one was to describe the activities and characteristics of the program that had usefulness and were perceived as being successful experiences for the mentors; secondly, the activities and characteristics were analyzed from the viewpoint of the proteges; thirdly, mentor and protege responses were compared to determine concurrence and divergence; and finally, these findings from within mentor and protege groups and between the two groups were compared in an effort to provide guidance for those individuals responsible for educational administration programs in their efforts to prepare more effective administrators. This study was designed as an initial study to open the way for procedural processes review and more specific investigations. 
SUMMARY AND CONCLUSIONS

\section{Perceptions}

Nonsignificant differences were found $(p<0.05)$ for all test statistics ( $t$-test and chi-square) which suggested that there were few differences between proteges and mentors in the way they perceived the mentorship program. In addition, Kendall's coefficient of concordance suggested that collectively the mentors and proteges had little agreement concerning the rank-ordering of program attributes. This was also true for each group. The overall perception of the program seemed to be that all participants were satisfied. The mean values of the Likertlike scales ranged from 1.9 to 2.2 .

Concerning same gender and cross gender mentor/protege pairing, more women than men felt that having a mentor of the same gender was helpful, although it was not clear whether these women had had a male mentor with whom to compare. Most respondents simply felt that having a mentor of the same gender was irrelevant. After reading the responses, the researcher questioned that somehow, becoming a "true" leader, the gender of the mentor should not matter. Because of this assumption, perhaps many respondents did not feel they were able to answer honestly on this issue for fear that this might be used against them, even if their responses were kept confidential. Because 27 of the 32 responding mentors and only 11 of the 28 proteges thought 
gender difference was irrelevant, the researcher wondered if the mentors may have felt more secure in answering honestly since they already had administrative positions. Most mentors and proteges felt that age made little difference in the mentorship. A minority of proteges felt similar age was important, and they were more likely to have had similar experiences and be at similar stages in life. It appears that similar experiences seemed to be more appropriate for matching pairs than similar ages. Concerning mentor and protege expectations and outcomes of the year-long mentorship program, the results showed moderate concordance for mentors and low concordance for proteges. Because different variables were asked the mentors and proteges, comparison groups would be inappropriate. In addition, the question format may have been confusing as not all participants completed both columns indicating expectations and indicating outcomes. It appears that mentors may have had fewer or lower expectations than did the proteges going into the program. Mentors may have been more content with their administrative role or position held. Because of the significant number of proteges (40 out of 51 proteges as reported in question 47) who commented that securing an administrative position was a goal, expectations may have been more specific or more goaloriented toward an outcome. 


\section{structure}

The results suggest little difference between mentors and proteges as to how they perceived the structure of the program. However, statistical significance was found concerning differences between mentors and proteges in how they perceived the usefulness of the directives and guidelines. Proteges were slightly less satisfied than mentors.

statistically significant differences existed between mentors and proteges in their perceptions of whether or not goals were established. More mentors than proteges felt that a year-long goal was established. Statistical significance was also found concerning the value of site visitations, perhaps related to the fact that proteges were more likely than mentors to make site visitations.

The questions with ratings suggested that, in general, mentors and proteges were satisfied with the structure. with a few notable exceptions concerning perception of usefulness of directives/guidelines and goal setting, mentors and proteges were satisfied with the structure.

\section{Logistics}

No significant differences existed between mentors and proteges regarding geographic distance as a negative factor in the mentoring process. However, the mean rating suggested that participants were fairly unsatisfied with geography as being a negative factor. This statistic may 
have been due to the wording of the question; respondents may have been confused by the wording utilizing a negative. significant differences existed between respondents and whether or not site visitations were conducted. The relationship between these two variables was dependent. The standardized residuals suggested that all cells of the contingency table contribute to this dependent. One can generally say, however, that proteges were more likely to visit their mentors than vise versa.

\section{Participant Relationships}

No significant differences existed in any of the items concerning the participant relationship category. Mentors and proteges viewed and responded in similar ways to each of the attributes or questions. In the majority of cases, feedback was given, letters of recommendation were written, help in job search was provided, and about equal numbers of relationships were maintained after the formal mentorship year ended.

Respondents' written comments yielded a number of suggestions for practice and research. Concerning gender as a factor effecting the relationship, respondents' comments included: "Quality of the candidate, not the gender is the important factor for me." "I do not strongly identify gender issues related to current issues of administrative leaders." "I don't think that our professional sharing and trust building was based on gender." 
The importance of on-going program evaluation included comments such as:
- - As I have indicated throughout, the concept is fine. The problem is the content. The dinners were without substance. I am social and enjoy visiting and dinner out, but speakers on educational trends, school issues, leadership styles, school reformation, . . . could have enriched the evening and been a topic of conversation during informal meetings. Expectations and standards should be clearer. The plan is too person specific to say success lies with the program. The people make it so.
The need for a more formalized and rigorous selection process and the matching process was a concern to mentors and proteges. Comments such as: ". . . the pairing of the mentor and protege should be the most important element in the project. Without compatibility, the poor protege is doomed to failure." "She was a very reserved person. Not really willing to help an administrator. . . " ". . it just depends on the match." "I was so displeased with my mentor. - He never really had time for me and I felt it." "Really depends on the person you get. I was very lucky. We hit it off and decided to do our own thing. . but it was very difficult if you did not have a good match." "My disappointment in the project mainly centered around the match with my mentor. . "

Respondents commented on mentor characteristics that they believed to be advantageous to the mentoring process. "I personally appreciate time colleagues spent with me over the years. Professionally, I feel I have an obligation to promote growth and development." ". . I wanted insights 
into personal and professional life. My mentor was not interested." "I feel good about being in a helper, facilitator role. I like to see others reach their goals." setting a year-long goal clearly was a high priority to proteges. "I had to establish goals for myself." "He may have had some for me which I am not aware of." "I don't recall having a single goal." ". . we did talk to each other about what we each hoped to achieve as a result of the program."

The importance of added structure was mentioned by mentors and proteges. ". - Expectations should be clearer. The plan is too person specific to say success lies with the program." "This was an unusual situation for me, one that was confusing for me and really still is: What was my responsibility, as an individual, a mentor, a professional?"

Time as a factor drew comments from the respondents. "Unfortunately, I was matched with someone who had very little time and energy for this program. . ." "It was often hard to synchronize schedules." "Yes! My building principal encouraged my participation and allowed me to spend as much time as I could with my mentor." "Obviously, if one is committed to something, one spends time on it." "Time is imperative." "It was difficult to treat the experience as an important priority." 
A problem solving process appeared to be important for mentors and proteges if the pairing process was flawed. ". - because the relationship with my protege was strained, I kept my time even further limited." "My disappointment in the project mainly centered around the match with my mentor. . . I began to realize that my mentor didn't have much to share with me."

". . I was very badly matched with my mentor. . I realize I should have done something to correct the problem. - . There should be a way to correct mismatches. Instead of the experience I expected, and that I feel most proteges had, I felt devalued by my mentor. Because there is not a second chance, an important opportunity was lost to me. Please correct this problem in what I still believe is an excellent program."

\section{IMPLICATIONS FOR PRACTICE}

If best professional practices are to be included in the Oregon Mentorship Program for both mentors and proteges, then it is incumbent on the program to devise a system for ongoing summative and formative evaluation to drive necessary changes as the program grows and matures. It is the writer's belief that continuance of programs based on the "cult of the personality" are ultimately doomed. A program of this type should be dynamic, not static. If there are no changes made to any program in effect as long as the Oregon Mentorship Program, it is probable that changes are needed in order to keep pace with the cutting 
edge in the field of education as well as minor fine tuning and adjustments.

In practice, another consideration needs to be examined; that of the difference in the legal status between those in the private sector and those of us who are educational professionals. When seen in this light, there are real differences. For example, the tenured status as teachers for both mentors and proteges provides a measure of security not available in the private sector. For this reason, considerations such as gender as a barrier to a successful mentoring relationship need to be addressed. First, the rules governing male/female conduct in the school as opposed to the workplace are much clearer and apt to be addressed. Historically, there has always been a large concentration of women as teachers and to a lesser extent as administrators. A post World War II phenomenon was the installation of males to replace female retirees. The civil rights tumult of the 1960 s has somewhat reversed that trend, again through legal actions that carry a great deal of clout. The protection of tenure in Oregon allows both males and females the benefit of knowing what is acceptable. As noted in Chapter 3, gender difficulties were very frequently alluded to in the literature in formal mentorships. This was not the case in this descriptive study. This mentorship program or any other similar effort, also needs to look at how selections are made for 
participants. It would be well to have some published standards for inclusion that are known to all mentors and proteges. If not, the selection and matching patterns seem haphazard, for example, the paucity of mentors from eastern and southern Oregon and the coast and the lack of a discernable process to effect an appropriate match between mentors and proteges.

Formal mentorship programs may be enhanced by an established selection process for both mentors and proteges. The Oregon Mentorship Program may want to create criteria, an application process, and selection procedures to ensure that the program includes mentors who possess certain characteristics. Characteristics to be considered might be administrative expertise, open channels of communication, availability, time, ability to clarify job expectation, and spiritual support. An effective administrator may or may not make a successful mentor just as an effective teacher may not make an effective administrator. Just because an administrator is known to members of the Confederation of Oregon School Administrators or Northwest Women in Educational Administration, he/she may or may not possess characteristics considered to be most valued by those in a position to be mentored. Expectations to be considered for a mentor may include accessibility to help the protege to cope with a difficult situation, high level of honesty, and willingness to give direct feedback. In addition, mentor 
expectations should include being an experienced, effective administrator, providing unscheduled opportunities to spend time with a protege, and the ability to reduce the sense of conflict and anxiety often felt when approaching or entering into a position change. The mentor should possess the ability to provide a protege with an opportunity to determine his/her own sense of professional direction and approaches to learning. It may be appropriate to review the literature on ineffective mentoring along with effective mentoring characteristics before establishing the selection process for mentors.

significance was noted in terms of the perceptions of mentors and proteges with respect to the issue of a yearlong goal. The proteges were far less comfortable with this aspect of the program than were the mentors who were satisfied with the goal-setting component of the pairing. Establishing a year-long goal in writing would be beneficial to mentorship pairs. The goal could be multifaceted to include individual learning objectives, monthly meeting places and/or times, informal learning opportunities, reading suggestions, or quiet sharing times. It might be appropriate to share a copy of the written goal with the mentorship program director.

Although the Oregon Mentorship Program was loosely structured purposely, added structure or even a template for structure along with clear directives would benefit the 
proteges. The data from the survey indicated that the mentors were comfortable with the flexibility of few directives but that increased structure would be desirable according to the proteges.

Consideration of a two-year commitment may improve the Program. The extension from one year to two years would allow for a variety of opportunities for the mentor and protege. Included in these opportunities could be such attributes to the program, such as, staggered entry years so that mentors and proteges would benefit from interaction with twice as many colleagues, although the program would still maintain an increase of just 20 new proteges and mentors each year. The additional year would allow for time to establish a professional relationship, more flexible time schedules during the summer months, and opportunities for the proteges to visit additional Program mentors' work sites. Increasing the length of the commitment may allow for each protege to have two mentors, to meet in small groups of proteges with one or more mentor, to form a learning group of two or three proteges to read and discuss educational journals, effective schooling practices, or educational legal issues. It may also reduce the anxiety of trying to "do it all" in just nine months from september through June.

Some incentive may need to be provided for the mentors, particularly if the program were extended to two 
years. Most mentors participated as a professional responsibility, commitment of COSA or NWEA, or for professional growth. If a cadre of mentors across the state was selected and trained as mentors, then possibly cosA could provide complimentary registration to coss=aponsored conferences, workshops, and professional growth sessions during the year of participation.

Some provision for problem-solving, facilitating concerns, and/or possible reassignment of mentor/protege pairings needs to be incorporated into the Program. Both mentors and proteges need an avenue to express concerns, utilize the services of a facilitator, or have an opportunity to be reassigned in another mentoring relationship.

Asking each protege to keep a log or reflective journal to document their activities, concerns, and thoughts would greatly enhance learning and the mentoring opportunity. At the joint dinner meetings or meetings of proteges only, participants might be prepared to share one or two entries, questions, or concerns. This could assist in increased learning and/or problem-solving.

\section{RECOMMENDATIONS FOR RESEARCH}

As stated in Chapter $I$, the current study was descriptive in nature, focusing on the Oregon Mentorship 
Program and its activities and characteristics. The researcher examined the perceptions, structure, logistics, and participant relationships of the mentor and protege participants in the program. This study is but one "snap shot" of a much larger venue of mentoring. Research studies replicating this study on related formal and informal mentorships should be conducted.

of particular interest is the exploration of unrepresented groups, such as, women and minorities in educational administration. Because the Oregon Mentorship Program had a goal to provide opportunities for women and ethnic minorities, the program may not represent accurately 2wantthe equity issue for other mentorship programs. Future studies may wish to explore women in educational administration and how they garner support and/or a mentor. What do women need as they pursue leadership positions in education?

Research needs to be conducted to determine if mentorships for aspiring or beginning administrators truly are vital to becoming effective administrators. Does the mentoring within preservice make a significant difference? Is it as important as preservice course work or practicum experiences? If mentored administrators are truly more effective, can the increased effectiveness be measured in improvement for students? 
As the researcher examined the responses concerning expectations and outcomes, the question arose as to how many administrators were truly trained for the positions they hold today. Because schools work much the same today as they did twenty years ago yet the world has changed so greatly, has present training changed enough to prepare adequately school administrators for the 1990 s and twentyfirst century? Aspiring administrators are often advised to follow the traditional path from assistant principal to principal to central office; is there a research base to support that taking the traditional path leads to more effective administrative practices and ultimately positive outcomes for students?

Mentoring has been emerging as an integral component in preservice training within university settings, at the individual school district level, in the form of induction processes and both formally and informally at the site level. The value of mentorships to the participating individuals and the organizations needs to be explored further. It seems imperative that practice and research be linked. Presently, practice and research are often parallel, logically, they should be circular; research leading to preservice administrative training that leads to practice and back to research as the circle continues. Future researchers will wish to examine the relationship between more skilled administrators and 
improvement of education. Do mentorship programs truly presume that the association between the mentor and mentee will result in some measure of "quality control" for those who have been mentored? Does mentoring make a difference? 


\section{REFERENCES}

Alleman, E., Cochran, J., Doverspike, J., \& Newman, I. (1984, February). Enriching mentoring relationships. Personnel and Guidance Journal, 62(6), 329-332.

Anderson, E. M., \& Shannon, A. L. (1988, January-February). Toward a conceptualization of mentoring. Journal of Teacher Education, 39(1), 38-42.

Ary, D., Jacobs, L. C., \& Razavieh, A. (1985). Introduction to Research in Education. New York: CBS College Publishing.

Auster, D. (1984, Spring) . Mentors and Proteges: Powerdependent dyads. Sociological Inquiry, 54(2), 142153.

Beeler, C. (1988, July). Teaching tomorrow's leaders through mentoring. Parks and Recreation, 23(7), 40,42-43.

Bennis, W., \& Nanus, B. (1985). Leaders: The strategies for taking charge. New York: Harper and Row.

Blackburn, R. T., Chapman, D. W. \& Cameron, S. M. (1981). "Cloning" in academe: Mentorship and academic careers. Research in Higher Education, 15(4), 315327.

Borman, C., \& Colson, S. (1984, March). Mentoring--An effective career guidance technique. The vocational Guidance Ouarterly, 32(3), 192-197.

Bowen, D. D. (1985, February) . Were men meant to mentor women? Training and Development Journal, 39(2), 3134 .

Bower, A., \& Yarger, G. (1989, Summer). Mentor-intern relationships in New York state's formal program: Beginnings. Action in Teacher Education, 11(2), 6065.

Brooks, D. M., Ed. (1987). Teacher induction - A new beginning. Association of Teacher Education. Reston, VA. 
Burke, R. J. (1984, September). Mentors in organizations. Group and orqanization Studies, 2(3), 353-372.

Burke, R. J., \& Mckeen, C. A. (1989, winter) . Developing formal mentoring programs in organizations. Business ouarterly, 53(3), 76-79.

Calkins, E. V., Arnold, L. M., Willoughby, T. L., \& Hamburger, S. C. (1986, September). Docents' and students' perceptions of the ideal and actual role of the docent. Journal of Medical Education, 61 (9), 743748 .

Campbell, D., \& Stanley, J. (1963). Experimental and quasiexperimental designs for research. Boston: Houghton Mifflin.

Campbell-Heider, N. (1986, Fall). Do nurses need mentors? Image: Journal of nursing scholarship, 18(3), 110111.

Carden, A. D. (1990, April). Mentoring and adult career development: The evolution of a theory. The Counseling Psychologist, 18(2), 275-299.

Carnegie Forum. (1986). A nation prepared: Teachers for the 21st century. New York: Carnegie Corporation of New York.

Carter, K. (1988, Summer). Using cases to frame mentornovice conversations about teaching. Theory Into Practice, 27(3), 214-222.

Chao, G., \& O'Leary, A. (1990, summer). How others see same-and-cross-gender mentoring. Career Planning and Adult Development Journal, 4(3), 3-12.

Clark, R. W., \& zimmer, B. P. (1989, May). Mentoring: Does it work? Lifeleng Learning, 12(7), 26-28.

Clark, S., Corcoran, M. (1986, January-February). Perspectives on the professional socialization of women faculty. Journal of Higher Education, 57(1), 20-43.

Clawson, J. G. (1985, April). Is mentoring necessary? Training and Development Journal, 39(4), 36-39.

Clawson, J. G. \& Kram, K. E. (1984, May-June). Managing cross-gender mentoring. Business Horizons, 27(3), 2232. 
Clemson, R. I. (1987, Fall) . Mentorship in teaching. Action in Teacher Education, 2(3), 85-92.

Clewett, E. D. (1984). Supporting and facilitating the entry teaching year: A summary of related literature and pilot program for oregon beginning teachers. A report prepared for the Oregon Association of Colleges of Teacher Education.

Coleman, J. (1981). Public and private schools. United states Government Document. ED 1(115), 96.

Conant, J. (1963) The education of American teachers. New York: McGraw-Hill.

COSA Mentorship Program. (1990) . COSA Foundation, 707 13th Street SE, suite 100, Salem, OR, 97301-4035.

Cronan-Hillix, T., Gensheimer, L. K., Cronan-Hillix, w. A., \& Davidson, W. S. (1986, October). Students' views of mentors in psychology graduate training. Teaching of Psychology, 13(3), 123-127.

Daloz, L. A. (1983, September). Mentors: Teachers who make a difference. Change, 15(6), 24-27.

Dalton, G. W., Thompson, P. H., \& Price, R. L. (1977, Summer). The four stages of professional careers - A new look at performance by professionals. organizational Dynamics, $6(1), 19-42$.

Daresh, J. C., \& Playko, M. A. (1989a, October). The administrative entry year program in ohio: A resource guide. Project paper of the Ohio Lead Center, Westerville, OH., 1-101 (ERIC Document Reproduction Service No. ED 311543 EA 021 310)

Daresh, J. C., \& Playko, M. A. (1989b, October). Administrative mentoring: A training manual Project paper of the Ohio LEAD Center, Westerville, $O H$ and the Center for Educational Leadership at the University of Northern Colorado. (ERIC Document Reproduction Service No. ED 315844 EA 021 506)

Daresh, J. C.. \& Playko, M. A. (1989C, March) . Kentoring for leadership development. Paper presented at the annual meeting of the Association for Supervision and Curriculum Development, Orlando, FL. (ERIC Document Reproduction Service No. ED 304775 EA 020790 ) 
Daresh, J. C., \& Playko, M. A. (1989d, March). A resource guide to assist local schools support beginning administrators. Paper presented at the annual meeting of the National Council of states on Inservice Education, San Antonio, TX. (ERIC Document Reproduction Service No. ED 315866 EA 021 586)

Daresh, J. C., \& Playko, M. A. (1989e, Summer). Teacher mentors and administrator mentors: Same track, different trains. Planning and changing, 20(2), 8991.

Daresh, J. C. \& \& Playko, M. A. (1990a, April). Mentoring for effective school administration. Urban Education, $25(1), 43-54$.

Daresh, J. C., \& Playko, M. A. (1990b, April). Preservice administrative mentoring: Reflections of the mentors. Paper presented at the annual meeting of the American Educational Research Association, Boston, MA. (ERIC) Document Reproduction Service No. ED 320203 EA 021 789)

DeBolt, G. P. (1989, August). Helpful elements in the mentoring of first year teachers Report to the state Education Department on the New York state mentor teacher-internship program for 1988-1989. (ERIC Document Reproduction Service No. ED 316501 SP 031 818)

Dix, J. E. (1990, March) Tacit knowledge of career experts in the establishment stage related to career success in the work environment. Paper presented at the annual meeting of the American Association for Counseling and Development, Cincinnati, OH. (ERIC Document Reproduction Service No. Ed 316777 CG 022 324)

Eberspacher, J., \& Sisler, G. (1988). Mentor relationships in academic administration. Initiatives, 51(4), 2732 .

Edmonds, R. R. (1979a, October). Effective schools for the urban pool. Educational Leadership, 37, 15-27.

Edmonds, R. R. (1979b) . Some schools work and more can. Social Policy, 9 , 28-32.

Edmonds, R. R. (1982, December). Programs of school improvement: An overview. Educational Ieadership, 40, (3), 4-11. 
Fagenson, E. A. (1988, June). The power of a mentor: Proteges' and nonproteges' perceptions of their own power in organizations. Group and organization studies, 12(2), 182-194.

Fagenson, E. A. (1989). The mentor advantage: Perceived career $/ \mathrm{job}$ experiences of proteges versus nonproteges. Journal of organizational Behavior, 10, 309-320.

Farren, C., Gray, J. D., \& Kaye, B. (1984, NovemberDecember). Mentoring: A boon to career development. Personnel, 61(6), 20-24.

Fink, A., Kosecoff, J. (1985). How to conduct surveys. Beverly Hills, CA: Sage Publications, Inc.

Flach, D. H., Smith, M. F., Smith, W. G., G Gasser, M. L. (1982, July). Faculty mentors for medical students. Journal of Medical Education, 57(7), 514-520.

Flesch, R. (1955) - Why Johnny can't read. New York, Harper-Row.

Forsyth, P. B. (1987, September). Viewpoint: Next steps for excellence. The School Administrator, $44(8), 48$.

Fox, S. M., \& singletary, T. J. (1986). Deductions about supportive induction. Journal of Teacher Education. 37(1), 12-15.

Galvez-Hjornevik, C. (1986) . Mentoring among teachers; a review of the literature. Journal of Teacher Education, 37(1), 12-15.

Gay, I. R. (1987) . Educational research: Competencies for analysis and application. Columbus, OH: Merrill Publishing Company.

Gehrke, N. J. (1988a, January-February) - On preserving the essence of mentoring as one form of teacher leadership. Journal of Teacher Education, 39(1), 4345.

Gehrke, N. J. (1988b, Summer) - Toward a definition of mentoring. Theory Into practice, 27(3), 190-94.

Gerstein, M. (1985, October). Mentoring: An age old practice in a knowledge-based society. Journal of Counseling and Development, 64(2), 156-157. 
Gladstone, M. S. (1988). Mentoring: A strategy for

learning in a rapidly changing society. Stainte Anne de Bellevue, Quebec: John Abbott College. (ERIC Document Reproduction Service No. ED $308727 \mathrm{HE} 021$ 553)

Goetz, J., \& LeCompte, M. (1984). Ethnography and qualitative design in educational research. orlando, FL: Academic Press, Inc.

Gray, w. A. (1986, winter). Formalized mentoring. Canadian Public Administration, 64(4), 636-638.

Guba, E. G. (1978) . Toward a methodology of naturalist inquiry in educational research. CAE Monograph Series in Evaluation, 8 . Los Angeles: University of California, Los Angeles, Center for study of Evaluation.

Guerrero, F., Schoener, J., Eisler, J., \& DeSalvio, M. (1989, March). A potpourri of staff development practices: What works/what doesn't. Paper presented at AERA Conference, San Francisco, CA. (ERIC Document Reproduction Service No. ED 311564 EA 021 335)

Hack, R. H., \& Blaine, D. D. (1989, March). The effects of colleague-pairing induction program on the perceptions of first-year teachers and their mentors. Paper presented at the annual meeting of the American Educational Research Association, San Francisco, CA. (ERIC Document Reproduction Service No. ED $310088 \mathrm{sp}$ 031382 )

Hagerty, B. (1986, January-February). A second look at mentors. Nursing outlook, 34 (1), 16-19.

Hamilton, E. (1942). Mythology. Boston: Little, Brown \& Company.

Hamilton, S. F. (1989, March). Learning on the job. Apprentices in West Germany. Paper presented at the annual meeting of the American Educational Research Association, San Francisco, CA. (ERIC Document Reproduction Service No. ED 305481 CE 052 207)

Harcastle, B. (1988, Summer). Spiritual connections: Proteges' reflections on significant mentorships. Theory Into Practice, 27(3), 201-208.

Haring-Hidore, M. (1987, November). Mentoring as a career enhancement strategy for women. Journal of Counseling and Development, $\underline{66}(3), 147-148$. 
Harper, S. L. (1988, April). An annotated bibliography of current literature on the mentoring of teachers: Collegial mentoring promotes dual professional growth [Research project in crs e591]. South Bend: Indiana University. (ERIC Document Reproduction Service No. ED 311029 SP 031 492)

Hawk, P. (1986-87, Winter). Beginning teacher programs: Benefits for the experienced educator. Action in Teacher Education, 8 (4), 59-63.

Heathington, B. S., Cagle, L. C., \& Blank, M. A. (1988, Spring). Seeking excellence in teacher education: A shared responsibility. Teacher Education, 23(4), 1929.

Hennecke, M. (1983). Mentors and proteges: How to build relationships that work. Training, 20(7), 36-41.

Hennig, M. \& Jardim, A. (1977). The managerial woman. Garden City, New York: Doubleday.

Hill, S. E. K., Bahniuk, M. H., \& Dobos, J. (1989, January) . The impact of mentoring and collegial support on faculty success: An analysis of support behavior, information adequacy, and communication apprehension. Communication Education, 38, 15-33.

Hilton, C. D., Kuehnle, S., Scholl, S., \& Zimpher, N. (1988, March). An induction program that invigorates the new and experienced. [Speeches/conference papers]. (ERIC Document Reproduction Service No. ED 299661 EA 020 212)

Hoffman, J., Edwards, S., O'Neal, S., Barnes, S., \& Paulissen, M. (1986). A study of state mandated beginning teacher programs. Journal of Teacher Education, 37(1), 16-21.

Homeier, G. A. C. (1953). An analysis of current administrative procedures used in the orientation of new teachers in Michigan public high schools. Published doctoral dissertation. Wayne state University, Detroit, MI.

Huffman, G., \& Leek, S. (1986) . Beginning teachers' perceptions of mentors. Journal of Teacher Education, $\underline{37}(1), 22-25$. 
Huling-Austin, I. (1986). What can and cannot reasonably be expected from teacher induction program. Journal of Teacher Education, 37(1), 2-5.

Huling-Austin, I. (1988, April). A synthesis of research on teacher induction programs and practices. Paper presented at the annual meeting of the American Educational Research Association, New Orleans, IA. (ERIC Document Reproduction Service No. ED 302546 SP 030821 )

Huling-Austin, I., Barnes, S., \& Smith, J. (1985) . A research-based development program for beginning teachers. Paper presented at the Annual Meeting of the American Educational Research Association, Chicago, IL.

Huling-Austin, L. ; \& Others. (1989). Assisting the beginning teacher. Reston, VA: Association of Teacher Educators. (ERIC Document Reproduction Service No. ED 212248 , SP 031 601)

Hunt, D. M. \& Michael, C. (1983). Mentorship: A career training and development tool. Academy of Management Review, 8(3), 475-485.

Isaacson, N. (1986). Socialization of secondary teachers. Fugene, OR: University of Oregon.

Ishler, P. (1988, October). A report on successful teacher induction programs: The whys, whats, and wherefores for Texas. Paper presented at the annual Texas Conference on Teacher Education, Dallas, TX. (ERIC Document Reproduction Service No. ED 301562 SP 030 732)

Jacoby, D. (1989, December). Rewards make the mentor. personne1, 66(12), 10-14.

Johnson, J. (1980). Mentors: The key to development and growth. Training and Development Journal, 34(7), 5557.

Kanter, K. E. (1977) Men and women of the corporation. New York: Basic Books.

Kaufmann, F. A., Harrell, G., Milam, C. P., Woolverton, N., \& Miller, J. (1986, May). The nature, role, and influence of mentors in the lives of gifted adults. Journal of Counseling and Development, 64(9), 576-578. 
Keele, R. L., \& DelaMare-Schaefer, M. (1984). So what do you do now that you don't have a mentor. Journal of NAWDAC, 47(3), 36-40.

Kizilos, P. (1990, April). Take my mentor, please! Training, 27(4), 49-55.

Klauss, R. (1981, July-August). Formalized mentor relationships for management and development programs in federal government. Public Administration Review, 489-496.

Kram, K. E., (1983). Phases of the mentoring relationship. Academy of Management Journal, 26, 608-628.

Kram, K. E. (1985a, April). Improving the mentoring process. Training and Development Journal, 39(4), 4043.

Kram, K. E. (1985b). Mentoring at work: Developmental relationships in organizational life. Glenview, IL: scott, Foresman.

Kram, K. E., \& Isabella, L. A. (1985) . Mentoring alternatives: The role of peer relationships in career development. Academy of Management Journal, 28(1), 110-132.

Krupp, J. A. (1984). Mentor and protege perceptions of mentoring relationships in an elementary and secondary school in connecticut. Paper presented at the Annual Meeting of the American Educational Research Association. New orleans, LA.

Krupp, J. A. (1985, October) . Mentoring: A means of sparking school personnel. Journal of Counseling and Development, 64(2), 154-155.

Krupp, J. A. (1987, August). Motivating experienced school personnel. Unpublished manuscript.

Lawrie, J. (1987, March) . How to establish a mentoring program. Training and Development Journal, 41(3), 2528 .

Lea, D., \& Leibowitz, Z. (1983). Would you know one if you saw one? Supervisory Management, 28(4), 33-35.

Levinson, D. J., Darrow, C. N., Klein, E. G., Levinson, M. H., McKee, B. (1978). Seasons of a man's life. New York, Alfred A. Knopf. 
Lipsitz, J. (1983). Successful schools for young adolescents. New Brunswick, NJ. Transactional Books.

Merriam, S. (1983, Spring). Mentors and proteges: A critical review of the literature. Adult Education Quarter1y, 33(3), 161-173.

Miller, L. M., Thomson, W. A., \& Roush, R. E. (1989, February). Mentorships and the perceived educational payoffs. Phi Delta Kappan, 70(6), 465-467.

Million, S. K. (1988, November). Training mentors and proteges: The key to successful mentoring programs. Paper presented at the annual conference of the National Council of states on Inservice Education, New orleans, IA. (ERIC Document Reproduction Service No. Ed 314363 SP 031650 )

Missirian, A. (1982). The corporate connection: Why executive women need mentors to reach the top. Englewood Cliffs, NJ: prentice-Hall.

Mosser, J. w., Deady, C., \& Kleisner, B. (1989, April) . co-mentoring: A career development alternative to the conventional mentoring relationship. Kalamazoo College. (ERIC Document Reproduction Service No. ED 300 746)

Mumford, A. (1985, May). What's new in management development. Personnel Management, 17(5), 30-33).

Naisbitt, S. (1982). Megatrends. New York: Warner Books.

National Commission on Excellence in Education. (1983) . A nation at risk: The imperative for educational reform. Washington, DC: United states Government printing office.

Noe, R. A. (1988a, Fall). An investigation of the determinants of successful assigned mentoring relationships. Personnel Psychology, 41(3), 457-479.

Noe, R. A. (1988b) . Women and mentoring: A review and research agenda. Academy of Management Review, 13(1), 65-78.

Noller, R. B. (1982) Mentoring: A voiced scarf. Buffalo, NY: Bearly, Ltd. 
Ochberg, R. I., Tischler, G. I., \& Schulberg, H. C. (1986, September). Mentoring relationships in the careers of mental health administrators. Hospital and Community Psychiatry, 37(9), 939-941.

Packard, R. D., Others [sic]. (1988, November). Educational change and reform, An integrated model for the professional development of teacher leaders. Paper presented at the annual conference of the National Council of States on Inservice Education, New orleans, IA. (ERIC Document Reproduction Service No. ED 302530 SP 030 801)

Parkay, F. W. (1988, Summer). Reflections of a protege. Theory Into Practice, 27(3), 195-200.

Patton, M. Q. (1990). Qualitative evaluation and research methods. Second Edition, Newbury Park, California: Sage Publications, Inc.

Pence, L. J., (1989a). Formal and informal mentorships for aspiring and practicing administrators. published doctoral dissertation. University of oregon, Eugene, OR.

Pence, L. J., (1989b, March). Mentorship programs for aspiring and new school administrators. Oregon School Study Council, University of oregon. oscc Bulletin, $\underline{32}(7)$.

Phillips-Jones, L. (1983, February). Establishing a formalized mentoring program. Training and Development Journal, $\underline{37}(2), 38-42$.

Playko, M. A., \& Daresh, J. C. (1988, October). A training institute for administrative mentors. A project report of the Danforth Foundation-Ohio state University program for the preparation of school principals. Columbus, $\mathrm{OH}$, Ohio University, College of Education. (ERIC Document Reproduction Service No. ED 299680 , EA 020 412)

Playko, M. A., \& Daresh, J. C. (1989, October). Beginning principals: Entry year programs and principal development. Paper presented at the annual meeting of the University Council for Educational Administration, Phoenix, Az. (ERIC Document Reproduction Service No. ED 311586 EA 021362 )

Ragins, B. R. (1989) - Barriers to mentoring: The female manager's dilemma. Human Relations, $\underline{42}(1), 1-22$. 
Rawlins, M. E., \& Rawlins, L. (1983, October). Mentoring and networking for helping professionals. Personnel and Guidance Journal, $\underline{62}(2), 116-118$.

Reich, M. H. (1985, March). Executive views from both sides of mentoring. Personnel, $62(3), 42-46$.

Reich, M. H. (1986, February). The mentor connection. Personnel, 63 (2), 50-57.

Rice, B. (1989, April) . Off-the-job training. currents, $15(4), 18-21$.

Richards, W. H., Robinson, M. E. (1989, April). An examination of Maine's new certification support system as it relates to administrator perceptions of their effectiveness. Paper presented at the annual meeting of the New England Educational Research Organization, Portsmouth, NH. (ERIC Document Reproduction Service No. ED 318077 EA 021 073)

Roche, G. R. (1979). Much ado about mentors. Harvard Business Review, 57, 14-28.

Rogers, J. C., (1986, February). Mentoring for career achievement and advancement. American Journal of Occupational Therapy, $40(2), 79-82$.

Rogus, J. F., \& Drury, w. R. (1988, May). The administrator induction program: Building on experience. NASSP Bulletin, 22(508), 11-16.

Rossen, C. I., Roth, K. J., \& Lanier, P. E. (1989, March). Field experience that teach: Mentor/faculty roles. Paper prepared for presentation at the annual meeting of the American Educational Research Association, San Francisco, CA. (ERIC Document Reproduction Service No. ED 307254 SP 031 167)

Schein E. (1978). Career dynamics: Matching individual and organizational needs. Reading, MA: Addison-Wesley.

Schmidt, J. A., \& Wolfe, J. S. (1980, Winter). The mentor partnership: Discovery of professionalism. NASPA Journal, 17(3), 45-51.

Schmuck, P. A., Giannone, D., \& Robbins, w. (1991, January). The oregon mentorship program for school administrators. Unpublished Article, 1-7. 
Schockett, M. R., \& Haring-Hidore, M. (1985). Factor analytic support for psychosocial and vocational mentoring functions. Psychological Reports, 57, 627630 .

Sergiovanni, T. J. (1984, February) . Leadership and excelience in schooling. Educational Leadership, 41(15), 4-13.

Serlen, B. (1989, winter). How mentoring programs work. Journal of Career Planning and Emplovment, 49(2), 5456.

Shapiro, E. C., Haseltine, F. P., \& Rowe, M. P. (1978, Spring). Moving up: Role models, mentors, and the "patron system." Sloan Management Review, 19(3), 5158 .

Sheehy, G. (1976, April). The mentor connection: The secret link in the successful woman's life. New York Magazine, 5, 33-39.

Showers, B. (1982). Transfer of training: The contribution of coaching. (Final report). Eugene, OR. University of Oregon Center for Educational Policy and Management.

Showers, B. (1984). Peer coaching and its effect on transfer of training. Paper presented at the annual meeting of the American Educational Research Association. New Orleans, LA.

Showers, B. (1985, April). Teachers coaching teachers. Educational Leadership, $\underline{42}(7), 43-48$.

Shute, R. W., Webb, C. D., \& Thomas, G. J. (1989, March). Implications of preparing school administrators: Mentoring. Paper presented at the annual meeting of the American Educational Research Association, San Francisco, CA. (ERIC Document Reproduction Service No. ed 311581 ea 021 352)

Stahlhut, R., \& Hawkes, R. (1989, February). A conceptual model for mentoring student teachers. Paper presented at the annual meeting of the Association of Teacher Educators, St. Louis, Mo. (ERIC Document Reproduction Service No. ED 304405 SP 030 913)

Stewart, D. K. (1986). ERIC resources on teacher induction. Journal of Teacher Education, 37(1), 35-37. 
Stroble, E., \& Cooper, J. M. (1988, Summer). Mentor teachers: Coaches or referees? Theory Into Practice. 27(3), 231-236.

Swerdlik, M. E., \& Bardon, J. I. (1988). A survey of mentoring experiences in school psychology. Journal of School Psychology, 26, 213-224.

Taylor, A. (1984, May). Women as leaders: The skills at which we are so uniquely qualified. vital speeches of the Day, 50(14), 445-448.

Tekerman, J. T. , \& Mendez, F. (1989, January) . Turn teachers into principals. The Executive Educator, 11(1), 14-15.

Thesaurus of ERIC Descriptors, (1990). Twelfth Edition. Oryx Press, Pheonix, AZ., 161.

Thies-Sprinthall, I., \& Sprinthall, N. A. (1987). Experienced teachers: Agents for revitalization and renewal as mentors and teacher educators. Journal of Education, 169(1), 65-79.

Warring, D. F. (1990, July). A collaborative mentor-mentee program. Paper prepared for the World Assembly of the International Council on Education for Teaching. (ERIC Document Reproduction Service No. ED 320894 SP 032 454)

Warring, D. F., \& Lindquist, M. (1989, February) . A collaborative mentor-mentee program based in the Bloomington, Minnesota, public schools. Paper presented at the annual meeting of the Association of Teacher Educators, st. Louis, Mo. (ERIC Document Reproduction Service NO. ED 305328 SP 030 955)

Webster's Third New International Dictionary of the English Language Unabridged (1986) . Merriam-Webster, Inc. Springfield, MA., 1412 .

White, E. R., \& Swezig, G. W. (1989, Spring). The Kentucky principal testing and internship program. Teacher Education, 24(4), 21-28.

Willbur, J. (1987, November) - Does mentoring breed success? Training and Development Journal, 41(11), 38-41.

Woodlands Group, The. (1980, November). Management development roles: Coach, sponsor and mentor. Personnel Journal, 59(11), 918-921. 
Wright, C. A., \& Wright, S. D. (1987, January). The role of mentors in the career development of young professionals. Family Relations, 36(2), 204-208.

Yoder, J. D., Adams, J., Grove, S., \& Priest, R. F. (1985, March). To teach is to learn: Overcoming tokenism with mentors. Psychology of Women Quarterly, 2(1), 119-131.

Zaleznik, A. (1977). Managers and leaders: Are they different? Harvard Business Review, 55, 67-78.

Zey, M. G. (1984). The mentor connection. Homewood, IL: Dow Jones-Irwin.

Zey, M. G. (1985, February). Mentor programs: Making the right moves. Personnel Journal, 64(2), 53-57.

Zey, M. G. (1988, January). A mentor for all. Personnel Journal, 67(1), 46-51.

zimpher, N. I., \& Rieger, S. R. (1988, Summer). Mentoring teachers: What are the issues? Theory Into Practice, 27(3), 175-182. 


\section{APPENDIX A}

SURVEY INSTRUMENT-QUESTIONNAIRE 


\author{
A DESCRIPTIVE STUDY \\ OF THE \\ OREGON MENTORSHIP PROGRAM
}

GUESTIONNAIRE 
Gaynelle Nols

2630 Northwest Westover

Portland. Oregon 97210

(503) 224-1081

March 1, 1991

Dear Oregon Mentorship Partictpant:

Your response to this survey is crittical. You are one of only elghty mentors or proteges being surveyed, and your feedback may create changes in the way mentor programs are designed and implemented in the future.

Please take a few minutes to give me information concerning the (COSA) Oregon Mentorship Program. This questionnaire is being sent to mentors and proteges who particluated in the COSA Program from its inception in 1986. through year four. 1990. I am gathering this information as part of a doctoral dissertation in Educational Leadershlp and Supervision at Portland State Untversity. I am asking that you please take the time (approxtmately 20 minutes) to complete the questionnaire and return it by March 13; I have provided an addressed and pre-stamped envelope for your convenfence.

All questionnaires are coded to assist me in the data collection process. However, the information from the questionnaires will be complled in such a way as to not Identify any one Individual who has completed a form; your response will not be personally identiflable beyond the point of aggregate data collection; your responses will be confdentlal. I will not be sharing the data prior to summation with any organization. If you would like a summary of the data, please contact me.

I realize that this questionnaire is undoubtedly one of many requests for your time and I thank you in advance for your response to it. Your input is valuable to my research, and 1 look forward to recelving your survey on or before March 13.

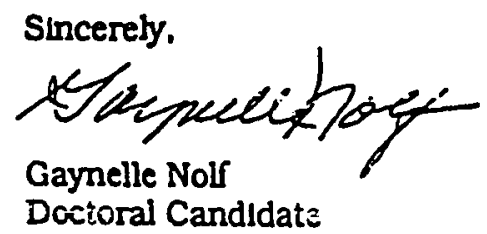


code number

A GUESTIONNAIRE DESIGNED TO GATHER DESCRIPTIVE DATA CONCERNING THE OREGON MENTORSHIP PROGRAM

DIRECTIONS: PLEASE ANSWER EACH OF THE FOLLOWING QUESTIONS BY MARKING DIRECTLY ONTO THE SURVEY FORM. THE SAME SURVEY FORM IS BEING SENT TO MENTORS AND PROTEGES. THEREFORE. MAKING IT IMPORTANT THAT YOUR RESPONSES CONSISTENTLY REFLECT YOUR ROLE AS A MENTOR OR AS A PROTEGE DURING THE YEAR YOU PARTICIPATED. ONCE YOU HAVE COMPLETED THE SURVEY, PLEASE RETURN IT BY MAIL IN THE ENCLOSED PRE-STAMPED ENVELOPE. I APPRECLATE YOUR WILINGNESS TO SHARE YOUR EXPERIENCES AS A MENTOR OR PROTEGE.

\section{SECTION I}

1. Were you a mentor or a protege during your year with the COSA Oregon Mentorshlp Program? Please check one.

$$
\text { mentor }
$$$$
\text { protege }
$$

PLEASE CIRCLE THE NUMBER THAT APPLIES FOR EACH OF THE FOLLOWING QUESTIONS BY USING THIS SCALE:

$$
\begin{array}{ll}
1 \text { = very satisfled } & 2 \text { = satisfled } 3=\text { neutral } \\
4 \text { = dissatisfied } & 5 \text { = very dissatisfled }
\end{array}
$$

2. How would you rate your year-long experlence in the (COSA) Oregon Mentorshlp Program?
1
2
3
4
5

3. How would you rate the program's value in the process of preparing effecttve school administrators?
1
2
3
4
5 
PLEASE CIRCLE THE NUMBER THAT APPLIES FOR EACH OF THE FOLLOWING QUESTIONS BY USING THIS SCALE:

$$
\begin{aligned}
& 1=\text { strongly agree } 2=\text { agree } \quad 3=\text { undecided } \\
& 4=\text { disagree } 5=\text { strongly disagree }
\end{aligned}
$$

4. Answer only one: $4 \mathrm{~A}$ OR $4 \mathrm{~B}$ :

A. Was the fact that your mentor/protege was the same gender helpful?

$\begin{array}{llllll}1 & 2 & 3 & 4 & 5\end{array}$

B. Was the fact that your mentor/protege was the opposite gender helpful?

$\begin{array}{lllll}1 & 2 & 3 & 4 & 5\end{array}$

Please briefly explain why (optional):

5. Were you and your mentor/protege well-matched with respect to temperament, work style, and personallty. Circle the number that applies?
1
23
4
5

6. Was geography (distance between mentor and protege) a negative factor in your mentoring experlence?
1
2
3
4
5

Approximately how many mlles (one way) from each other did you live/work?

$$
=\text { miles between mentor and protege }
$$


7. Answer only one: 7 A OR 7 B:

A. Was age difference a negative factor in your mentoring relationship?

$\begin{array}{lllll}1 & 2 & 3 & 4 & 5\end{array}$

B. Was age difference a positive factor in your mentoring relationshlp?

$\begin{array}{lllll}1 & 2 & 3 & 4 & 5\end{array}$

Please briefly explain (optional):

8. Was adequate time a factor in providing a rewarding and significant mentoring experdence for your mentor/ protege?

$\begin{array}{lllll}1 & 2 & 3 & 4 & 5\end{array}$

Please explain brielly:

9. Were the directives, the overview of mentorship characteristics, and the guidellnes stated with enough clarity for you and your mentor/protege to establish an effective mentoring relationship?
1
2
3
45

10. Did you vist your mentor/protege at his/her school or oflce during the year-long program? Check one. 
11. Did you have release time or a flexdble school-day schedule to particlpate in visitations?

— yes _ no

Please explain brielly:

12. DId you and your mentor/protege develop a year-long goal? Check one.

yes $\quad$ no

Please state brielly what your year-long goal was:

13. Which of the following best describes the frequency with whlch you met (face-to-face) with your mentor/ protege? Check the one answer that applies.

_daily __weekly w__ monthly bimonthly

four scheduled program dinner meetungs only

fewer than four times

never

14. Which of the following best describes the frequency with whlch you had telephone conversations with your mentor/protege. Check the one answer that applles. dally weekly monthly bimonthly prlor to the four scheduled dinner meetings only

fewer than four times never 
15. Please answer only one: $15 \mathrm{~A}$ OR $15 \mathrm{~B}$ :

Please indicate in rank order which of the following were your expectations as you began, and your per ceptions of the outcomes as you ended your year in the Mentorshlp Program. Place the number "l" next to your highest expectation in the column labeled expectations and your highest outcome in the column labeled outcomes, the number " 2 " next to your second highest expectation and second highest outcome, etc. The number "10" should be placed next to the expectation and the outcome that you considered to be of least importance. (Remember to fill out only ONE: elther 15 A for mentors OR 15 B for proteges.)

"A" (mentors to flll out) EXPECTATIONS OUTCOMES

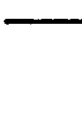

to increase my commitment as a professional

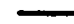

to increase my personal satisfaction by showing concem for others

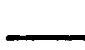

to have an opportunity to discuss professional issues and educational trends

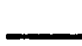

to establish or increase my professtonal network

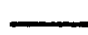

to Increase vislbillty and/or opportunity for potentlal career advancement

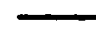

to improve my job satusfaction

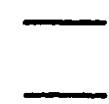

to incrcase peer recognition

to help develop managerial and leadership talent

to create energy and redirect my productivity by passing on wisdom and expertise

to assess my skills as an administrator 
"B" (proteges to flll out)

EXPECTATIONS

OUTCOMES

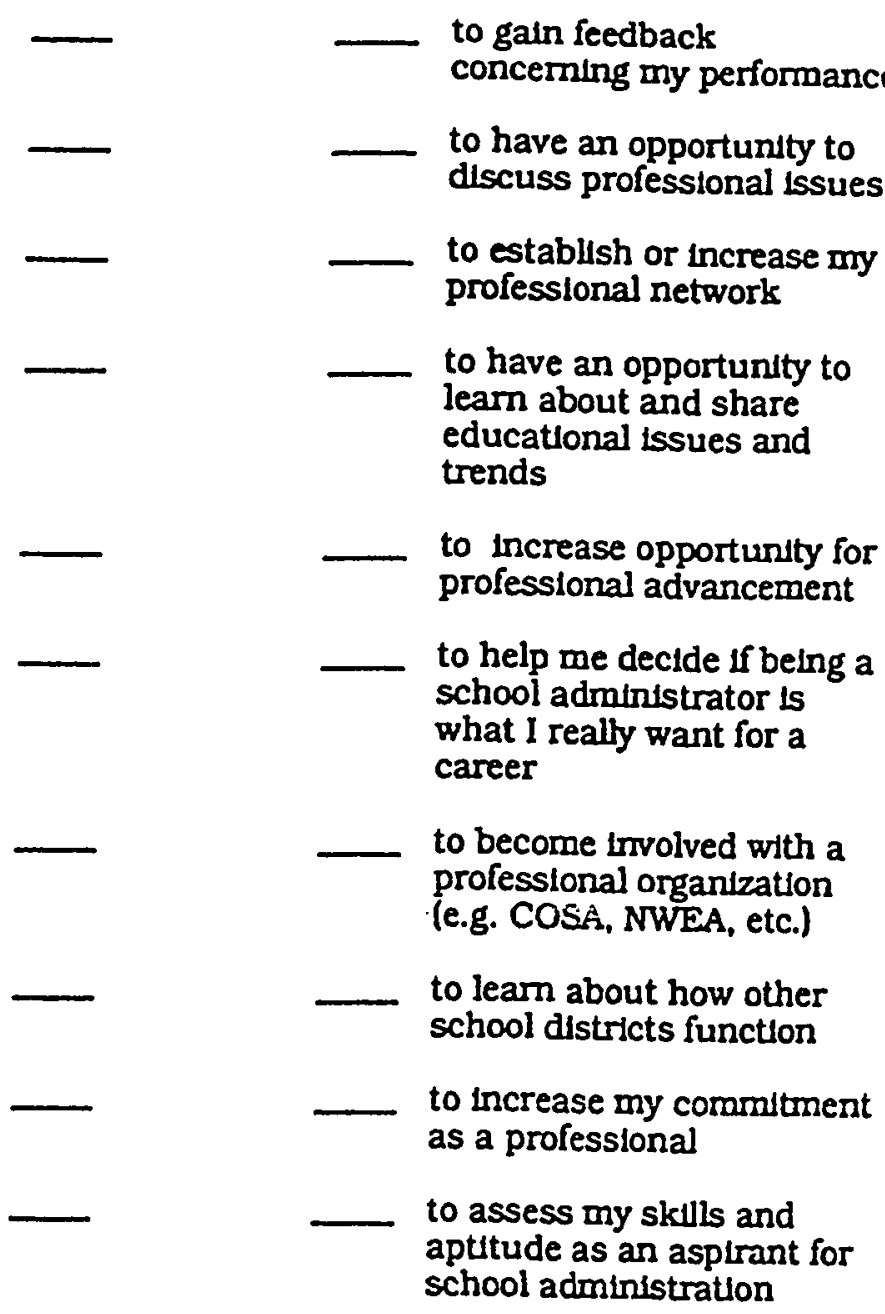

16. How many of four (4) scheduled dinner meetings did you attend? Please place one number.In the blark provided.

dinner meetings 
PLEASE CIRCLE THE NUMBER THAT APPLIES FOR EACH OF THE FOLLOWING QUESTIONS BY USING THIS SCALE:

$$
\begin{aligned}
& 1=\text { strongly agree } 2=\text { agree } \quad 3=\text { undecided } \\
& 4=\text { disagree } \quad 5=\text { strongly disagree }
\end{aligned}
$$

17. The informal structure (e.g. dinner meetings with open sharing opportunittes, verbal suggestions at the first meeting for establishing a mentor-protege relationship. etc.) of the Oregon Mentorship Program posituvely influenced my mentorship experience.
1
2
3
4
5

18. The support of my mentor (or if you were a mentor, your expertence mentoring a protege...) positively influenced II.' progress toward understanding the role of an administrator and educational leader.
1
2
3
4
5

19. The four COSA-planned dinner meetings were important components of the mentorship to facllitate communication.
1
2
3
4
5

20. Telephone conversations with my mentor/protege were an important means of communication throughout the year.
1
2
3
4
5

21. Face-to-face informal (non COSA planned) meetings with my mentor/protege were an important means of communicating with my mentor/protege.
1
2
3
4

5 
22. Aftending conferences/workshops with my mentor/ protege served as important learning opportunities for me.

$\begin{array}{lllll}1 & 2 & 3 & 4 & 5\end{array}$

23. Site visitations at the school/once of my mentor/ protege were valuable experiences for me.

$\begin{array}{lllll}1 & 2 & 3 & 4 & 5\end{array}$

THE NEXT SERIES OF QUESTIONS WILL REQUIRE A "YES" OR "NO" RESPONSE FROM YOU. PLEASE CHECK IN THE SPACE PROVIDED.

24. Did you provide lor if you were a protege. did you recetve...) specinc and concrete feedback about performance?<smiles>[13CH3][13CH3]</smiles>

25. Was assistance provided by the mentor to the protege in a job search or position change?

yes

no

26. Were you asked by your protege (or as a protege. did you ask your mentor...) to write a letter of recommendation?

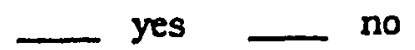

27. Have you continued a professlonal relationship with your mentor/protege after the planned year-long program ended?

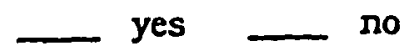

28. Did your program experience match the perceptions with which you began the year-long experience? 
THE NEXT TWO QUESTIONS WILL ASK YOU TO RANK ORDER ITEMS. PLACE THE NUMBER " 1 " NEXT TO THE FACTOR THAT YOU CONSIDER TO BE THE MOST IMPORTANT. THE NUMBER "2" NEXT TO THE SECOND MOST IMPORTANT FACTOR, ETC. THE NUMBER "10" SHOULD BE PLACED NEXT TO THE TENTH LEAST IMPORTANT FACTOR.

29. Please rank order the following attributes that you consider to be moportant to the success of any formal mentorship:

$$
\text { mentorship training for mentors }
$$

a rigorous selection process for proteges

clarity of program requirements

support of employer

availability of time

a formal selection process for mentors

mandatory meetings (e.g. the planned dinner meetings)

extstence of an informal support group

avallability of mentor/protege for contacts (phone or face-to-face meetings)

establlshing year-long goals at the onset of the expertence 
30. Please rank order the following list of activities in terms of your perception of their value to the Oregon Mentorshlp Program:

COSA scheduled meetings
self scheduled meetings with mentor/
protege
informal contacts with mentor/protege
professional networking acttvitles
_ spending time with your mentor/protege
opportunity for analysis of personal
strengths and weaknesses
social hour prior to dinner meetings
mutual goal setting
professional service

\section{SECTION III}

THIS LAST SECTION OF THIS QUESTIONNAIRE ASKS DEMOGRAPHIC QUESTIONS FOR STATISTICAL PURPOSES ONLY. AGAIN, YOUR RESPONSES WILL BE CONFIDENTIAL; DATA WILL BE COMPLED IN SUCH A WAY AS TO NOT DENTIFY ANY ONE INDIVIDUAL WHO COMPLETES A FORM. PLEASE FILL IN THE BLANK OR CHECK THE ONE ANSWER IN EACH QUESTION THAT BEST APPLIES. TWO QUESTION WILL REQUIRE A SHORT ANSWER RESPONSE.

31. Describe your professional status during your year of assoctation with the (COSA) Oregon Mentorship Program by writing in a one, two. or three word description of your position title in the space provided. (e.g. graduate student, teacher. special education coordinator, counselor, media speclalist, administrative intern, assistant principal, principal, personnel director, superintendent. etc.) 
32. Describe your current professional status. Please write a one, two. or three word description of your position title in the blank space provided.(e.g. graduate student. teacher. special education coordinator. counselor. media speclalist, administrattve intern, assistant principal, principal. personnel director. superintendent, etc.)

Are you at the elementary, middle school/funtor high. high school, district office, or other? Please specify in the space provided.

How long have you been in your present posttion? years months

Are you considered to be an administrator or a teacher according to your contract in your district? Please check one.

$$
\text { administrator _ teacher }
$$

Are you presently aspiring to a different position?

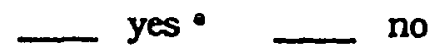

-If you responded with a YES, please explain:

33. How would you rate your career satisfaction? (Please circle the number that applies using the following scale: 1 = very satisfied: 2 = satisfied; 3 = neutral; 4 =dissatisfied: 5 = very dissatisfied)

$$
\begin{array}{llllll}
1 & 2 & 3 & 4 & 5
\end{array}
$$

34. Please indicate your highest level of education attalned or highest degree conferred by fllling in the blank provided. (e.g. BS/BA; MA/MAT/MS; enrollment in an administrattve program; administratuve certificate; enroliment in doctoral program; Ph.D./Ed.D.; etc.) 
35. Please indicate the total number of years you have been an educator (teacher/counselor/specialist/ administrator) by filling in the number in the blank provided.

$$
\text { years }
$$

36. As a partictpant in the Oregon Mentorship Program. what year (or years) were you a mentor/protege?

$1986-87$
$-1987-88$
$-1988-89$

37. Have you been a participant in another formal (planned) mentoring program? Please check the one that applles.

yes $\longrightarrow$ no

38. Do you have or have you had an Informal mentor or sponsor in your career?

$$
\text { yes }
$$

Please explain brledy:

39. Please indicate the number of years of teaching and/or administrattve experience at each of the following grade levels. (The total should be equal to the approprate category in question number 35).

$$
K-3 \longrightarrow 4-6 \longleftarrow 7-9 \amalg 10-12
$$

40. Please check your approprlate age category:

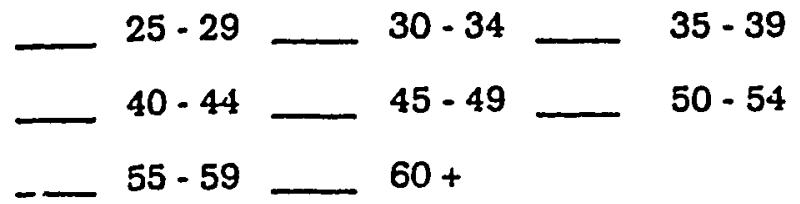


41. Please check the age category of your mentor or protege:

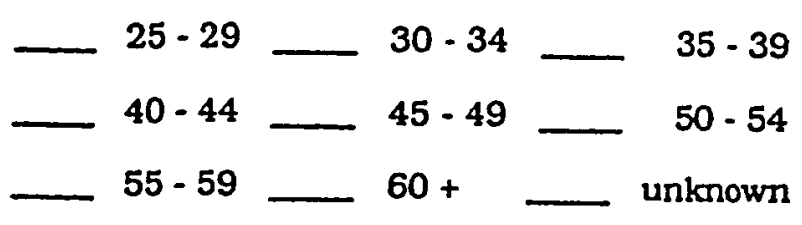

42. Please indicate your raclal/ethnic group:

\begin{tabular}{ll} 
Native American & Aslan American \\
African American & Hispanic \\
Caucaslan/White & Other \\
\hline
\end{tabular}

43. Please check the approprlate category:

$$
\text { male __ female }
$$

44. Please fll in the approxdmate number of students in your school district at the time you particlpated in the program.

$$
=\text {.district student population }
$$

45. If you were at the bullding level during the mentorship year, please fll in the approxdmate number of students in your school.

- $\quad$ school student population

46. Why do you think you were selected for the program? Please explain brienty in the space provided. 
47. If you were a protege, you applled and were selected to partlclpate; if you were a mentor, you were asked to participate by the coordinating committee. What were your personal or professlonal reasons for particlpating? Please explain briefly in the space provided.

PLEASE RETURN YOUR QUESTIONNAIRE IMMEDLATELY UPON COMPLETION. YOUR RESPONSE TO THE QUESTIONNAIRE NEEDS TO BE RECENVD BY MARCH 13. I APPRECLATE YOUR SUPPORT AND THANK YOU FOR TAKING THE TIME TO COMPLETE THE SURVEY.

mall to: Gaynelle Nolf

2630 Northwest Westover

Portland, Oregon 97210

If you have questions, please contact me. (503) $224 \cdot 1081$ 
ANY ADDITIONAL COMMENTS: 


\section{APPENDIX B}

WRITTEN RESPONSES FROM QUESTIONNAIRE:

MENTORS 
WRITTEN RESPONSES - KENTORS

Question 4: A: Was the fact that your mentor/protege was the same gender helpful?

B: Was the fact that your mentor/protege was the opposite gender helpful?

$1=s$ trongly agree

2=agree

3=undecided

$4=d i s a g r e e$

5=strongly disagree

a2 Overnight conferences.

a1 There was comfort in meeting in restaurants, in my home and other places without concern of male/female relationships.

a2 Approached mentorship/protege relationship with similar assumptions and conditioning. This strengthened communication.

b3 I don't think it made much of a difference.

a5 Wouldn't matter.

a2 Yes, we were able to openly discuss differential treatment, etc.

a3 I am very liberated on this issue.

a5 The gender of the protege had no bearing whatsoever on my experience in the program.

a3 I have informally mentored other administrative aspirants of the opposite gender.

a2 There are perspectives/experiences unique to being a woman in the field, and it's valuable to be able to share that.

b5 Gender makes no difference.

b3 I don't think it was a significant factor.

a4 Does not apply.

a4 I do not strongly identify gender issues related to current expectations of administrative leaders.

b3 Didn't matter. 


\section{WRITTEN RESPONSES - MENTORS}

a3 It made no difference to me.

a3 I'm not sure that gender is a relevant item for consideration.

a3 I don't think it matters.

a3 No difference.

a3 I don't think that our professional sharing and trust building was based on gender.

a4 Quality of the candidate, not the gender is the important factor for me.

a3 I don't think that is an issue.

a3 I don't think it would make a difference.

a3 I was a mentor 3 years ago to a woman. This year I have a man. The critical difference is distance not gender.

a3 I liked looking around and seeing a mix of gender pairs (felt it indicated advancement of equity).

a3 I have not found it an advantage or disadvantage--same or different gender. Depends entirely upon the person.

b3 Gender did not seem to be an issue. In our case the protege was a male, the principal a female. But gender issues were not an issue.

b3 What difference would it make?

b4 It really was/is irrelevant as to gender match. I work with males/females equally in my work ... so do they.

al Unfortunately, I believe there still exists some men who believe that they have little to learn from women. I think an older-ish man with a younger woman would be a poor match.

a4 Gender would have made no difference to me.

a2 I do not believe gender played a significant role; the fact that we were both women was easy but not a real factor. 
WRITTEN RESPONSES - YENTORS

Question 7: A:

Was age difference a negative factor in your mentoring relationship?

B: Was age difference a positive factor in

l=strongly agree your mentoring relationship?

\section{2=agree}

$3=$ undecided

$4=$ disagree

s=strongly disagree

b3 Didn't matter much.

b3 Same age.

a5 This was not an issue.

a $4 \mathrm{b2}$ I guess I mean experience rather than age.

a5bl My protege was about 12 years younger, which was perfect.

a5b2 Both mentorship experiences the age difference seemed irrelevant.

a5 Irrelevant.

a4 Again, age doesn't make a difference.

b3 There wasn't much of an age difference.

a5b5 We were not very different in age - or so it seemed.

a5 Didn't matter.

a5 There was not an age difference.

a3 Dian't matter.

a3 No difference.

a5 Chronological age insignificant in working relationships for me.

b5 Wouldn't make a difference.

a3b3 I don't know protege's age, but certainly our experiences personally and professionally were similar. 


\section{WRITTEN RESPONSES - YENTORS}

a5 Years of experience in administration was more important than any age differences.

b3 It didn't make any difference.

a4 Not a factor.

nr No - Hard to answer a negative with a negative.

a5b5 No difference in age.

a4 Age was not significant in the effect of the program.

a5b5 Age played no part as we were quite close.

Question 8: Was adequate time a factor in providing a rewarding and significant mentoring

1=strongly agree

experience for your mentor/protege?

2=agree

3=undecided

$1=$ disagree

$5=$ strongly disagree

1 We took the time to make the experience worthwhile.

2 Time to discuss issues and give feedback was critical.

2 Time is always a problem for secondary administrators.

5 our time was extremely limited.

1 The most valuable aspect of the program was when we were together in the car on the way to or from a mentor program meeting.

1 Couldn't find sufficient time to meet--Both working full time and married with families.

1 Finding time was a problem for both of us.

2 My time was limited because the relationship with my protege was strained, I kept my time even further limited.

1 We were able to work out many "real" administrative experiences. 


\section{WRITTEN RESPONSES - YENTORS}

2 Would have been good to have been able to spend some time with her at her school.

1 We had to create regular time to spend together or it wouldn't have worked.

2 Yes, we made it work because we took extra time to be together after school.

We didn't take the time to get together.

2 Due to distance, it was difficult to get together as much as I felt we should have. (60 miles)

Busy work schedules. Busy home schedules. Illness.

Both of us had demanding jobs. Time is always a problem.

1 It was difficult to treat the experience as an important priority.

4 We both had very busy schedules.

2 Always struggling to fit experiences in.

2 He was a coach--often times difficult to get together.

4 More time needed for protege to "shadow" me and observe variety of experiences/situations.

1 Time is imperative.

2 We were fortunate that she was supported to visit during work days, e.g., shadowing, observing principal interviews.

2 My protege was not a classroom teacher and had some time flexibility. This was certainly an advantage.

4 Time was a function of personal decision. The official meeting times did not add to the significance of the mentoring. Outside time did.

1 Difficult to get schedules to match.

1 The protege committed too little time to make it worthwhile. 
WRITTEN RESPONSES - MENTORS

2 Obviously - if one is committed to something, one spends time on it.

4 Distance and release time were negative factors.

2 Release time for protege was impossible which made it difficult to spend work time together.

2 We made time for the project.

2 Time is always a factor for administrators, particularly secondary site administration.

Question 9: Were the directives, the overview of mentorship characteristics, and the guidelines stated with enough clarity for you and your mentor/protege to establish an

1=strongly agree effective mentoring relationship?

$2=$ agree

3=undecided

$4=$ disagree

$5=s t r o n g 1 y$ disagree

2 We created our own.

Question 10: Did you visit your mentor/protege at his/her school or office during the year-long program?

Yes No

n We had expected to--

n She met at my office and shadowed me, too.

y Both, and she came to mine.

n He did visit at my school 3 times.

She was a University student on leave from her district. 


\section{WRITTEN RESPONSES - YENTORS}

Question 11: Did you have release time or a flexible school-day schedule to participate in visitations?

_ Yes__ No

y Flexible school day.

y As a school principal, I pretty much set my own schedule.

n I don't get those.

n We did it after school hours

$y$ My time as a principal allowed me the flexibility of scheduling visitations.

y I suppose I could have arranged it--I just didn't.

y We both had the ability to schedule time together.

n It would be terrific if proteges could have support this way with subs or extended pay.

y We both freed up our schedules for visitations. Our jobs allowed us that flexibility.

n She did. I worked her visits in anyway I could--No formal arrangement.

y I was a high school pxincipal. Time was not too much of a problem.

y I am an administrator so I could make flexible time arrangements.

n My protege was given no release time by her district-This was very discouraging to her.

$y$ My position allows a great deal of flexibility.

y We each took one day to visit each other's school.

n Protege did not have these available.

y There was no visit as she was not attached to a district.

y As a principal, this was not difficult for me. 
WRITTEN RESPONSEB - MENTORS

$y$ Easy for me - Harder for the protege.

y The protege decided to spend all shared time at my school.

$y \quad$ Iimited flexibility but we managed.

Question 12: Did you and your mentor/protege develop a year-long goal?

Yes No

n Don't recall.

y She (the protege) would get her placement file, resume, etc. ready to go.

nr can't recall.

Y 1. Improve interview skills.

2. Find a job.

$y$ To view all administrative roles in a high school.

$y$ I can't remember, it was two years ago.

y Loosely.

y Secure an administrative position.

y Focus on staff development and parent-school relationship.

$y$ To get him a job!

$y$ To clearly define one area that the protege could increase his administrative ability.

y To see a broad range of administrative duties.

y Getting a principalship (and she did)!

y We decided on several things we'd like to accomplish. She was particularly interested in the day-to-day routine and discipline (to the best of $\mathrm{my}$ recollection).

y To work through several issues related to school administration. 


\section{WRITTEA RESPONSES - MENTORS}

y I can't remember.

y To focus on nuts and bolts activities such as budgeting, scheduling, student activities, parent communication.

y Above and beyond text learning to delve into the "things" that an administrator can do to make a difference with students.

n Not a specific goal. Our discussions focused on whatever issues were important at the time.

y Expand knowledge of principalship. Develop specific skills in budget, personnel, leadership areas. Develop resume and supporting documentation.

Y To give him a realistic look at high school administration.

y Prepare for and obtain an administrative position.

y To help her get a job in administration!

y Informal one: to share administrative experiences and provide support in application process.

y To help her focus her career plans.

$y$ We developed goals in several areas: curriculum, leadership behaviors, communication skills, job preparation, readiness (interviewing, resume writing).

y Did needs assessment and developed goals and activities under each of these.

y Dealt with communication to patrons and staff (I think, it's been 5 years).

$y$ It was to engage her in each of the various areas encountered in a typical administrative assignment at the middle school.

y Several in specific areas of management.

y To share experiences to help prepare the protege for a principalship. 


\section{WRITTEX RESPONSES - MENTORS}

Y A qualified "yes" to this question. We did discuss goals, both short term and long range--but specifics were not included.

Question 13: Which of the following best describes the frequency with which you met (face-to-face) with your mentor/protege?

Check the one answer that applies. Daily weekly Konthly - Bimonthly$$
-
$$ four scheduled program dinner neetings fewer than four times Never

plus three more meeting at my school.

Four or five times.

Question 32 : Are you presently aspiring to a different position?

Yes _ No

? I'm undecided about becoming a superintendent vs returning to being a principal (currently Assistant superintendent).

y Larger district - Personnel.

$y$ District office.

Y Will be curriculum Director, July 1, 1991.

y Central administration.

$y \quad$ My position ends this year.

n However, always open to new possibilities.

y Changing Levels.

y Superintendent.

y Superintendent somewhere.

y Personnel director. 


\section{WRITTEY RESPONSES - MENTORS}

\section{Question 38: Do you have or have you had an informal} mentor or sponsor in your career? Yes so

y Listening to folks I respected. No political sponsor, per se.

n Personal belief system regarding my own professional growth.

y Informal support from past administrators.

y An informal mentor - one I gravitated to on my own.

n I haven't.

y I have always had someone in my district who served as a mentor.

y Someone(s) I later realized I had seen as a mentor; not formalized or discussed.

y Both, I have had wonderful mentors and have been a mentor to several vice principals.

y I had a mentorship relationship with a teacher in my district two summers ago.

y I have had several mentors.

$y$ Lots of peers, former bosses and colleagues with whoin I share and on whom I rely.

y CosA Springfield Assessment Program.

y MY superintendent has been a wonderful mentor.

y Frequently assist with interview preparation, resumes, advising - in education/arts/media.

y Mentored by Superintendent.

y Two of the people I worked for were mentors for me.

y Informal-My building principal. I visualize how he'd handle a problem, then do it!

y Several people have acted in this role. I have served in many different areas and so have had the opportunity to work with many outstanding people. 


\section{WRITTEN RESPONSES - MENTORS}

n Just my husband--an excellent mentor.

y Two at university level early in my career.

y Various administrators have assisted me with advice and/or formal recommendations when requested.

y Our new high school principal.

y Informal with two other principals.

y Three women who are currently completing administrative credentials.

y My building principal and the assistant superintendent when I taught.

y Several and various times, from undergrad years to ongoing female models/mentors.

y There have been many informal mentors from my first principal to our present superintendent and including several college professors.

y Through the years superintendents and other administrators have been specifically helpful.

y Someone I selected to help mentor me (actually several) that I could go to for advise and support.

y I've created my own mentors as I began new positions.

$y \quad$ New principals in large district.

y In a district program

Y My second principal. 


\section{WRITTEY RESPONSES - MENTORS}

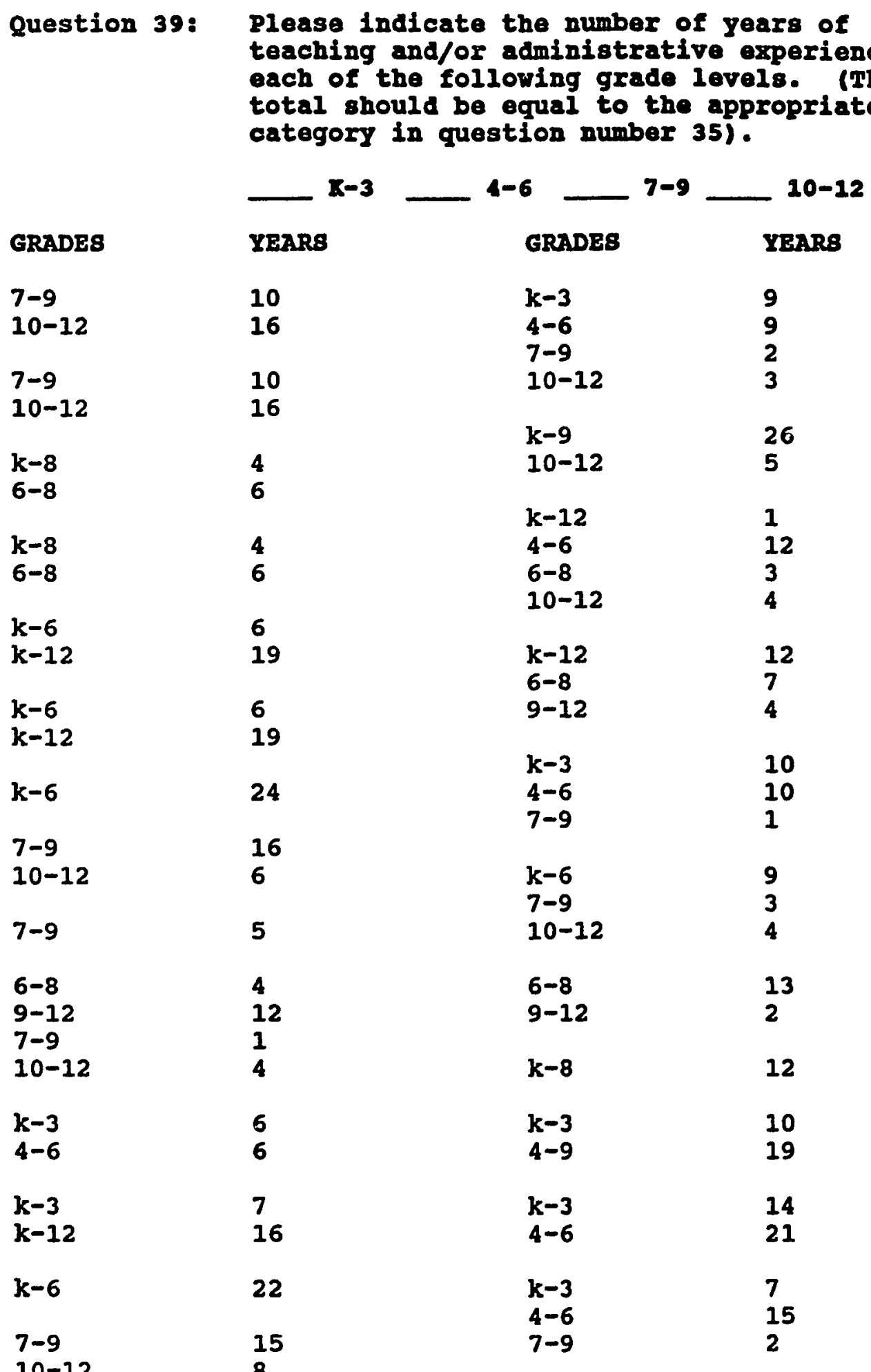




\section{WRITIEN RESPONSES - MENTORS}

\begin{tabular}{|c|c|c|c|}
\hline $\begin{array}{l}\text { GRADES } \\
k-3 \\
k-12\end{array}$ & $\begin{array}{l}\text { YEARS } \\
6 \\
16\end{array}$ & $\begin{array}{l}\text { GRADBB } \\
7-9 \\
k-12\end{array}$ & $\begin{array}{l}\text { YBARS } \\
2 \\
16\end{array}$ \\
\hline $\begin{array}{l}4-6 \\
7-9\end{array}$ & $\begin{array}{l}21 \\
5\end{array}$ & $\begin{array}{l}7-9 \\
10-12\end{array}$ & $\begin{array}{l}11 \\
11\end{array}$ \\
\hline $\begin{array}{l}4-6 \\
7-9 \\
10-12\end{array}$ & $\begin{array}{l}11 \\
4 \\
6\end{array}$ & $\begin{array}{l}k-6 \\
7-9 \\
10-12\end{array}$ & $\begin{array}{l}4 \\
7 \\
2\end{array}$ \\
\hline $\begin{array}{l}k-6 \\
7-9\end{array}$ & $\begin{array}{l}3 \\
13\end{array}$ & $\begin{array}{l}4-6 \\
7-9 \\
s p \text { ed }\end{array}$ & $\begin{array}{l}4 \\
8 \\
4\end{array}$ \\
\hline $\begin{array}{l}k-12 \\
10-12\end{array}$ & $\begin{array}{l}18 \\
4\end{array}$ & $\begin{array}{l}k-3 \\
k-6\end{array}$ & $\begin{array}{l}5 \\
13\end{array}$ \\
\hline $\begin{array}{l}k-6 \\
7-9 \\
10-12\end{array}$ & $\begin{array}{l}3 \\
6.5 \\
15.5\end{array}$ & $\begin{array}{l}\text { Resource } \\
7-9 \\
10-12\end{array}$ & $\begin{array}{l}2 \\
21\end{array}$ \\
\hline $\begin{array}{l}7-9 \\
7-12 \\
10-12\end{array}$ & $\begin{array}{l}16 \\
13 \\
21\end{array}$ & $\begin{array}{l}k-3 \\
4-6 \\
7-9\end{array}$ & $\begin{array}{l}3 \\
3 \\
18\end{array}$ \\
\hline $\begin{array}{l}k-3 \\
k-6\end{array}$ & $\begin{array}{l}3 \\
3\end{array}$ & $10-12$ & 1 \\
\hline $\begin{array}{l}4-6 \\
\text { District } \\
\text { University }\end{array}$ & $\begin{array}{l}1 \\
6 \\
4\end{array}$ & $\begin{array}{l}7-9 \\
10-12\end{array}$ & $\begin{array}{l}4 \\
18\end{array}$ \\
\hline $\begin{array}{l}k-6 \\
10-12\end{array}$ & $\begin{array}{l}6 \\
18\end{array}$ & & \\
\hline $4-8$ & 21 & & \\
\hline $\begin{array}{l}4-6 \\
7-9\end{array}$ & $\begin{array}{l}3 \\
20\end{array}$ & & \\
\hline $\begin{array}{l}k-3 \\
4-6 \\
k-8 \\
k-5\end{array}$ & $\begin{array}{l}11 \\
3 \\
3 \\
8\end{array}$ & & \\
\hline $\begin{array}{l}4-7 \\
9-10 \\
k-12\end{array}$ & $\begin{array}{l}9 \\
6 \\
8\end{array}$ & & \\
\hline $\begin{array}{l}k-3 \\
4-6\end{array}$ & $\begin{array}{l}6 \\
7\end{array}$ & & \\
\hline
\end{tabular}




\section{WRITTEN RESPONSES - MENTORS}

Question 46: Why do you think you were selected for the program?

Interest in mentor program. Previous experience with assessment center and springfield simulation.

I don't know the reason!

I don't have a clue!

Previous leadership roles in CosA.

Because I volunteered???

Recommend by colleagues familiar with my qualifications from COSA work.

I volunteered?? Our district has many up-to-date projects going on.

ozzy told me to!

I'm not sure.

I have a strong interest in developing future administrators, I am interested in personnel aspects of administration (resume writing, interviewing), and I am interested in growing as an administrator.

Previous leadership experience.

Asked to be involved.

I was known to the $\cos A$ staff.

I do a good job.

I don't know who thought of me or why. Perhaps because I checked a COSA questionnaire saying I'd be interested?

The person who asked me knew the quality of my work. I was recognized as an exceptionally successful administrator who had turned around a school program.

I told CosA I would be willing to help.

I met the needs of a protege.

My involvement in COSA and NWEA. I'm an old timer! 


\section{WRITTEN RESPONSES - MENTORS}

Maybe because I received the Distinguished Principal Award for $\mathrm{NW}$ region in _.. I'm currently participating in another mentor program through NW Region.

Because of my background and interest in helping new administrators.

School Recognition for Working with School climate. Location--Southern oregon. was close to protege.

I'm active in professional organizations, I've developed a collegial network, I lend support and follow through . . . They were desperate and needed a match?

My leadership skills

The success of our school district and its program.

Those who selected mentors knew me and my work?

Close association with candidate

Years of experience in the region

Career - aspirant match

enthusiasm

proximity

similar personalities

Reputation for being a person of competence and a visible supporter of administrative aspirants.

Experience as a high school principal.

I carry a positive reputation with the PPS as an innovative leader.

COSA participation and US Department of Ed National Award.

Someone in the COSA/NWEA office knew me.

Someone's recommendation, I suspect.

Knowledge of my style

reputation

position

At the time I was in a cosA leadership position and supported the start of the program. My protege's aspiration was a curriculum position and from a nearby district. I believe the selection committee felt we would be a good match. 


\section{WRITTEN RESPONSES - MENTORS}

I was part of the Lewis and Clark superintendent certificate program and Pat Schmuck was charged with finding mentors.

Position desired by protege and proximity.

Geographic reasons.

Recommendation of colleagues and supervisors.

Interest and desire.

Recommendation of District office.

Very few women in high school principalships in this area. Close to the same age.

My professional skills had been assessed by many through Project Leadership, my COSA offices held, and being Oregon principal of the year.

Professional familiarity with COSA, NWEA, etc. Manner and style of dealing with people.

Commitment to Mentoring.

Experience.

Question 47: If you were a protege, you applied and were selected to participate: if you were a mentor, you were asked to participate by the coordinating committee. what were your personal or professional reasons for participating?

It's hard to say "no" to someone you respect--eg. Pat Schmuck. Probably, if someone else had asked I would say "no." Also, I'd like to see higher quality people in administration and the pool of women is excellent.

I enjoyed the large group meetings--The choice of protege was "just OK." This person would not be of Administrative strength that would be hired by the participating school district. It was a good program and is needed but it is important to select the best for mentors and proteges.

I was honored to be asked and I thought I would learn a lot from participating. I was right!

1. I enjoy working with adults going into administration.

2. I feel a professional commitment to help others as I was helped. 


\section{WRITTEN RESPONSES - MENTORS}

I personally appreciate time colleagues spent with me over the years. Professionally, I feel I have an obligation to promote growth and development.

I must have felt I have something to offer. I was flattered to be asked. I was/am interested in knowing and learning from and about other administrators.

ozzie Rose wouldn't let me out of it.

I was interested in helping out an aspiring administrator reach his or her goal as a principal. I was also interested in sharing my experiences as an administrator.

It is time for me to "pay back" to the educational field some of the knowledge, skill, and ability that have enabled me to administrate on a variety of levels.

I felt honored and validated by being asked. I feel like my peers and professional organizations have contributed to my personal and professional development, and I wanted to reciprocate. As Jan Olson says, "Don't forget to reach out a hand back--someone was there for you." I think we need and deserve quality educators--I want to contribute to that development.

Wanted to help an aspiring protege.

To help develop instructional leaders. I had been a practicum supervisor and really enjoyed the process of briefing and debriefing what I was doing and why.

I was considering being an administrator trainer/professor in the future--thought this would help.

Was flattered by the committee member who asked.

I believe education needs good administrative leaders. It is my hope and desire to be able to work with individuals who are excited about education and working with young people.

I feel I have experience to share with someone new. Sharing ideas keeps me "fresh."

First, I felt an obligation because our COSA president personally asked me to participate. It was an honor to be asked and even thought I was very busy, I decided to make time. I also felt I had the knowledge and background that could help a new principal. I know it would have helped me. The opportunity to develop a relationship with someone 
WRITTEN RESPONSES - YENTORS

outside my own school district, and the fact the proteges had been closely screened appealed to me. I knew I'd be working with a quality candidate and not be wasting my time with an individual who had limited potential.

I was interested in assisting someone else as I had been assisted in the early days of my administrative career. I also felt that I had something to offer an aspiring principal because of both my experience and education. Finally, I felt I might learn something about myself and have the opportunity to look at my performance through the idealism of a younger educator.

1. Professional growth

2. Provide assistance

3. Challenge - new - different.

What goes around comes around. I'm in education to help people--parents, students, staff, etc. I have struggled to progress in the field and been helped by loving and intelligent people. I want to return that to the cosmic whole.

Helping someone.

Professional growth and learning.

NWEA was very important to me during my first years as administrator. The informal support, workshops, and friendship made a big difference. I wanted to provide that for someone myself.

To help a beginner--hopefully as a recruiting tool for our small area of the world.

-Sounded interesting.

-Always watching for professional relationships, someone with whom I can discuss issues, ideas.

-There's a special energy in such a relationship--it "fills up" rather than "takes."

To provide support, especially to women and male nonCaucasians, for entry into administrative ranks. To open doorways that I had to "break down" when I moved into school administration.

To give myself another leadership experience that would help me grow professionally.

I feel the qualities of administrators administering our school system must improve. It is very difficult to become 


\section{WRITTEN RESPONSES - MENTORS}

an effective administrator in isolation. The Mentor program should receive highest priority.

I felt it would be appropriate to share with aspiring administrators outside my district . . . good opportunity to meet some new people and to promote COSA, OASSA, etc. I saw this as a professional responsibility to "pass the flame."

I thought I could help. I entered administration in 1974 without a mentor and have never really had one. I wish I had had one.

I enjoy working and getting to know other educators. I enjoy the out of the school day contacts with my peers. I feel good about being in a helper facilitator role. I like to see others succeed in reaching their goals.

Though I had reservations the first year about the desirability of matching people unknown to each other in a mentoring relationship, I was honored to be asked - in the first group by a person I respected and I was very interested in having the statewide mentor interactions I'd had as a teacher leader. Since I'd been concentrating so much time instead on being in the building and $I$ am committed to nurturing others.

Encouraging and supporting qualified aspiring administrators is a personal goal. I have been a formal and an informal mentor for a number of aspirants. I find this very satisfying personally and strengthens our profession by securing these outstanding people. I believe we have a professional responsibility to support (and demand) the most ethical and skillful leaders for our schools.

I believe in mentoring as part of my personal commitment to my profession. I have been a practicum advisor for teachers, counselors and administrators. This seemed one more way I could contribute.

Hoped it would be growth producing for myself. A sense of giving something back to the system. Support of superintendent (encouragement).

Responsibility as a professional.

I considered it an opportunity to contribute to my profession. I am committed to the development of quality school administrators and I feel I have some skills, experiences, and abilities to offer to that end. I also 


\section{MRITTEN RESPONSES - YENTORS}

believe that the best way to learn is to teach and I'm always looking for ways to improve myself.

I wanted to meet administrators in areas other than in my district and I wanted a more personal experience. I feel it's our professional obligation to support each other and do more than stay in our own little niche.

Each time I mentor a protege, I learn more new ideas about administration in general and also about my own style. It is a great self analysis opportunity.

Help others enter the profession with more preparation and usable experience than I viewed coming in.

I was pleased to have been asked to be a mentor. I am convinced that mentoring is valuable and necessary within the career path. I am willing to give the time and energy to help beginners to experience success. I consider it "teaching."

I wanted to be of service to my profession. 
APPENDIX C

WRITTEN RESPONSES FROM QUESTIONNAIRE:

PROTEGES 
WRITTEY RESPONBES - RROTEGEB

Question 4: A: was the fact that your mentor/protege

B: Was the same gender helpful?

was the opposite gender helpful?

1=strongly agree

2=agree

3=undecided

$4=d i s a g r e e$

$5=s$ trongly disagree

a2 We got along well and could talk easily. I don't know if it would have been as easy with the opposite gender.

a5 I have since worked with a male mentor and his advise and our professional relationship has been even better than my COSA mentor's (which makes me think gender is not an issue.)

b4 I have had a number of informal mentors of opposite gender. One of same gender might have had different insights.

a3 I don't think it would make any difference.

b3 I can't see that it made any difference.

a3 No difference.

b3 I don't think gender had much to do with it. I'm, female and my mentor was male, but our mutual interest was curriculum.

$5 a b$ Really doesn't matter--it's the experience shared-Gender is for sexists.

b4 It wouldn't make any difference to me. The skills are the same--male or female.

a3 Although he was the same gender, I don't believe it would have made any difference to me.

a1 I appreciated a woman's insight to obstacles and situations in a male dominated (even "good ole boy") system.

a2 My mentor was the same sex and I appreciated this. 


\section{WRITTEN RESPONSES - PROTEGES}

Women in leadership positions often share styles and common philosophy. It was important, especially early on, that my instincts and prior experience were validated. Gender specific problems such as breaking up or mediating fights among boys, could be topics of conversation.

3b The actual mentor is what's really important. If they do a good job is all that matters.

b3 Really didn't make any difference.

b5 It didn't make any difference.

4a My mentor was not in the mood to mentor.

a3 Made no difference.

b4 Basic fact of gender was irrelevant

a4 It really didn't make any difference.

b3 It didn't make a difference. Gender had nothing to do with it.

a2 Common interests and activities provided information and suggestions helpful for women in administration.

a5 We are of different gender but friends for many years prior.

a3 It is easier to use the same sex person as a role model.

b2 Gender has nothing to do with quality of mentor at that time in my career, issues of gender were not most important. My mentor and I discussed gender and our different responses to an issue.

a5 She was a very reserved person. Not really willing to help aspiring administrator. She seemed to be like many women. Afraid to help because it might create competition or obligate her in some way. Very poor mentor.

a2 I could identify with her as a role model.

b3 Leadership qualities, skills, experiences, and what you put into the program "sees" no gender. 
WRITTEN RESPONSES - PROTEGES

a2 I rould identify with her problems because I too am a working mother with young children and I could see what I would have to deal with if $I$ was an administrator.

b4 I don't think gender had any effect either way.

a4 Gender did not play as much of a role as getting along. Personalities, interest, I believe played a bigger role.

a3 I don't believe gender was a factor.

b3 Neither my mentor nor I felt that our gender was an issue.

a2 We related to each other very well.

b3 The conversations I had with my mentor didn't focus on gender as it related to effective administration. Instead, we talked about qualities, characteristics and attitudes of good school leaders.

a5 Gender does not determine a successful, dynamic educational leader who is able to build an excellent school.

Question 6: Part b: Approximately how many miles (one way) from each other did you live/work?

1 My mentor was an administrator in the small community where I live. I think he saw me as a "parent" not "protege."

$5 \quad 15$ miles work; 5 miles home very accessible.

4 Beaverton - Gresham: work about 45 minutes drive. Garden Home - NW Portland: homes about 15-20 minutes.

nr Not miles but time--1 hour.

35-40 Corvallis to Salem.

b1 My mentor was about 10 years older. I appreciated her years of experience.

b3 No written. 


\section{WRITTEX RESPONSES - PROTEGEB}

a5 We were about the same age.

NR Not a factor.

a4 Age really played no role in my cosa mentorship experience.

a3b3 Age was not an obvious factor.

a3 Age would not matter to me.

b3 It didn't seem to matter.

a3 No difference.

b3 My mentor was about 15 years older than me, but it never was an issue.

nr Not applicable.

3a There was no age difference.

nr Neither - our ages were approximately the same and it wasn't a consideration.

a5 My mentor is older and that probably was an important factor.

Question 7: A:

Was age difference a negative factor in your mentoring relationship?

B: Was age differenca a positive ractor in

1=strongly agree your mentoring relationship?

2=agree

$3=$ undecided

4=disagree

5=strongly disagree

a5 We were close in age. That was important.

nr We were of similar age.

b3 Age had nothing to do with anything.

b3 Didn't enter into it.

nr There was very little age difference. 
WRITTEX RESPONSES - PROTEGES

alb1 We're about the same age.

al She was concerned by other issues in her life.

a5b5 No factor.

a5 age - irrelevant.

a2 I'm not sure whether age had anything to do with our relationship, but it was not a close one.

b3 Makes no difference.

a5b1 Neighboring districts.

a5 I don't believe that it influenced our relationship one way or the other.

nr There was no considerable age difference.

b2 Not age, but experience in regards to years or the job was positive. Age has no relevance to expertise.

a5b3 I don't think age was a factor either way.

a1 My mentor was getting ready to retire and didn't put much into the program.

a5 Our interest and ability to get along were what we dealt with, not age.

a5b3 I don't see age as a factor. I see ability and experience as primary factors.

b3 Mentor was perhaps 5 years younger. Being close to the same age with shared family/professional experiences was positive.

b1 Pretty close in age.

b2 If age difference played any part in our mentor/protege relationship, it would be that my mentor had a richer, more varied background to draw on from being around longer than $I$.

a5b2 The fact that my mentor had a number of successful years as an administrator was beneficial. He was able to share his many experiences. 


\section{WRITTEN RESPONSES - RROTEGES}

Question 8: Was adequate time a factor in providing a l=strongly agree rewarding and significant mentoring experience for your mentor/protege?

$2=$ agree

$3=$ undecided

$4=$ disagree

5=strongly disagree

1 My district gave me three days to spend at my mentor's school and I was able to spend many afternoons as well.

3 In our field time has a tendency to usually stifle the various programs so is the case in the mentorship.

2 It was often hard to synchronize schedules.

2 It was difficult to take time off from work to "shadow" my mentor at his school as often as I would have liked.

2 My mentor seemed reluctant to make time for me.

4 I had flexibility in my schedule--he (my mentor) did not.

2 Hard to get time.

$5 \quad$ Yes! My building principal encouraged my participation and allowed me to spend as much time as I could with my mentor.

1 We both were extremely busy! Making time was difficult but travel to meetings was an asset.

1 Never enough.

2 It would be much better if I were in the same building with him. No time for either of us to get together.

1 I which we had even more time and appreciate his continued mentoring.

4 I was given every opportunity to meet with my mentor; however, my schedule limited it. 
WRITTEN RESPONSES - PROTEGES

2 Adequate time together would have been helpful. Due to travel of mentor we were not able to get together as much as desired.

1 The more time able to meet made the experience that much more valuable.

5 Our mentoring relationship extended well beyond one year. We are still close friends and collaborate frequently on issues we both face.

1 We needed time to plan.

4 Seems like 2 years would be more helpful.

4 My district provided me with time off which I didn't even completely use.

2 Both of us already had very busy schedules.

nr Unsure.

1 I did not have a positive experience.

1 My district allowed 3 days of release time which proved invaluable.

1 Distance

Time

Job responsibilities

4 We had plenty of time to get together but waited too long to start things up; ended up rushing our relationship.

2 He always made time for my questions and concerns. We often talked on the phone.

2 We made time to make the program work for both of us.

2 More release time from my job and less distance would have been helpful.

3 After about 2 months there was no more contact between the two of us.

1 The protege must take the initiative to arrange time. 


\section{WRITTEN RESPONSES - PROTEGES}

3

5

1 Time spent together was time learning.

1 The time I put forth in structuring the relationship, activities, and goals were essential in providing the results I wanted.

2 Needed time to get to know each other and set up experiences.

1 We met briefly on 2 occasions and I visited his school for 1 day.

4 Because we were not far away, it was easy to arrange meetings.

1 It was difficult to find time. My district was not helpful in providing time.

2 It was difficult to arrange time off from the classroom, but I did get 3 days.

3 I would have appreciated more time but know between two busy schedules it was not possible.

2

Both my mentor and I were involved in major projects that limited the time we had available during the work week.

1 We met often and enjoyed all the time we spent together. I feel we took all the time we needed with each other to get the most from the program.

2 Yes, at times it was very difficult to find a suitable time to meet.

n I feel release time is extremely important.

y I was able to take "comp time" to meet with my mentor.

y I was given professional leave. 
WRITTEN RESPONSES - PROTEGES

y I needed time to travel to the general meeting of the entire group and was released by the district.

n I was acting as an administrative assistant. I had another mentor - my principal in my own building.

Y I'm an administrator and have flexible hours due to the support of my boss.

y My responsibilities did not allow me to take as much release time as desired. Maybe only 1 or 2 days.

n The district did not allow time off from work for visitations. It should be an understanding that this is part of thee training.

y But only for 1 visit.

y Beaverton provided the availability of comp time since I was an administrative assistant.

y I used my personal leave.

y I was able to receive one day of release time from my district.

n I took personal leave.

y days.

y If job responsibilities did not interfere.

Y Used 2 professional days.

n I used one day we had off and they were in session to observe.

Question 11: Did you have release time or a Elexible school-day schedule to participate in visitations? Yes _ No

y 3 full days of a substitute so I could visit full days.

y Prearrangement.

y I took the day off on two different occasions. 
WRITTEA RESPONSES - PROTEGES

n I had limited support from my building administrator for visitations during school.

$y$ Home district was very supportive of the program.

y I had to arrange professional leave to participate in visitations.

y The idea was never brought up.

y Made arrangement with my district.

y 3-4 days release time.

y My supervisor allowed me to flex schedule my classes. I used teacher work days and conference days.

Y My district/principal was very supportive of the program.

$y$ I left early in order to travel to salem. I could not cut into the school day.

y My district allowed time off to pursue this program. My principal allowed me to leave early.

n And this was a "big" problem --limited what we could do.

n I used a personal leave day to go visit my mentor's school.

n Although my district was aware of my participation, all release time was use of my personal time.

nr I took a leave day.

y Used combination personal leave and as I remember professional leave.

y My district was very supportive and allowed me all the time I requested.

y We each spent one full school day at each other's schools.

y I was able to spend $1 / 2$ day with my mentor at his building. 
WRITTEN REBPONSEB - PROTEGEB

Question 12: Did you and your mentor/protege develop a year-long goal? _ Yes _uo

y My goal was to shadow my mentor as well as take over for her for 2 days while she was at a conference.

n Mostly discussion and observations of ongoing happenings.

y My goal was to learn more about the daily activities and decisions that a principal must make.

n My mentor was primarily interested in helping with my resume. We did that. I wanted insights into balance between professional and personal life. My mentor was not interested.

y We had several goals set up interview practice and write resume.

Y To be able to spend time in a district office so that a "flavor" for an administrative career could be developed.

y Resume, application preparation, develop an idea of how to start in a new job. We shared communication techniques.

y Get a job

n He may have had some for me which I'm not aware of.

$y$ Identify strengths and capitalize on them. Create opportunities for professional growth. Develop communication/leadership skills.

y Support for me in whatever style, shape and however long it took for me to get an administrative position.

n I had to establish goals for myself.

y To help me develop an administrative mind set.

y Can't remember - a visit was the only one plus a revised resume.

y To assist in informational gathering about job responsibilities. 


\section{WRITTEX RESPONSES - RROTEGES}

y Several--I don't remember!

y To become familiar with policies, rules and procedures of administrative duties.

y To prepare resume, paperwork, and complete applications for potential administrative positions.

Y 1. Teacher Evaluations.

2. Daily operation of school.

3. Faculty decision-making/meeting format.

y To be involved in as many different areas as time allowed.

$y$ To identify areas of interest in the field of education administration.

y Area I worked toward included: . .

y We planned to accomplish certain activities by the end of the year and we did.

n I don't recall having a single goal.

y 1. Get to know each other professionally as well as personally.

2. Review of my paper work.

y Work on interviewing skills.

y Continuing dialogue regarding school discipline strategies.

y This was not very formal, but we did talk to each other about what we each hoped to achieve as a result of the program.

y We worked on a number of key areas all year: curriculum, teacher evaluation, parent and community relationships, positive programs for kids.

Question 32: Are you presently aspiring to a different position? Yes _ No

y Elementary Principal 


\section{WRITTEN RESPONSES - PROTEGES}

y I would like an administrative or curriculum position.

y Staff development position or elementary principal.

y I am still hoping for an administrative position but cannot use my mentor as any reference and feel if $I$ applied in his district he would work against me.

y Principal.

y Administrative classification.

$y$ Only for the right principalship.

y Middle school principal.

y Principal or Superintendent/Principal.

y I wanted to be a building administrator. I currently am.

y Elementary School Principal.

y I would like an assistant principal or staff development position.

y Elementary principal.

y I was a building principal at a very small high school before this assignment. I aspire to a principalship of a triple A school.

$y \quad$ VP in a school.

y Middle school VP or elementary principal.

y Relocation.

y Elementary principal--want closer association with students and teachers.

Y Advancement.

y Elementary school principal.

Y Superintendent.

y vice Principal. 
WRITHEY RESPONSES - PROTEGES

y Vice Principal or Grants Manager.

$y$ When an administrative comes available in this district, I will apply.

y I am interested in a curriculum coordinator, staff development or elementary principal position but cannot afford a decrease in salary and am unable to move from this area.

y I believe I can be a good administrator in a middle school or elementary school based on my experiences.

y Principal, curriculum specialist, special ed coordinator.

y Looking for an elementary principal position.

y I desire an administrative position as an elementary principal.

y Vice Principal or assistant administrator.

y Currently applying for special education administrator position.

y Intermediate school vice principal.

y I've applied for vice principal and team leader positions at the middle school level.

y Larger District.

Question 38: Do you have or have you had an informal mentor or sponsor in your career? _ Yes _ No

y Two principals I have worked with were mentors to me.

y A former principal of mine has been an informal mentor over the years.

Y I have a colleague who is an administrator with whom I have developed and cultivated a mentor relationship which replaces my "formal" CosA mentor. 
WRITTEN RESPONSES - PROTEGES

y All the principals I have worked with (3) have been strongly supportive of my career. I have had some excellent support.

y Several administrators have tried to convince me to go into administration.

y A former superintendent assisted me initially.

y Past employers are very helpful.

y Science colleagues.

y COSA - Mentorship for assistant principal--two people in my network.

y Principals I have worked with in my district.

Y My present boss and colleagues.

$y$ This year I am participating in an informal administrative intern opportunity. I am receiving a stipend to direct the IODE Beginning Teacher support Program in our district. I'm also invited to a series of administrative inservice workshops offered to district administrators. My assistant principal has been a source of support this year.

y I have worked with several principals over thee years who have been very willing to provide support and advice.

Y The superintendent who hired me from the classroom to the principalship was and is a mentor.

y Superintendent of a district.

y An administrator in district now retired.

$y$ The person who first encouraged me to become an administrator is still a mentor and advisor at this time.

y The principals I worked under as an administrative assistant acted as mentors.

y Principal and vice-Principal. 
WRITTEX RESPONSES - PROTEGES

y District administrators have mentored my career as I sought my first administrative position.

y COSA relayed to another assistant principal in area to be my "informal" mentor when I may have questions or concerns, etc.

y Fellow administrators.

y Two of the principals I have been assistants for have served as mentors to me.

y Building principal at both the middle and high school.

$y \quad$ Lots of former supervisors.

$y$ I currently have in informal mentor that I talk with about twice a year.

y Principal/supervisor for 3 years.

y I have several administrator colleagues who support me and assist me.

y Building principal I worked with as a teacher.

y My building principal has been encouraging and supportive.

y I have had many "mentors" along the way help me but not any specific person over a long period of time.

y Peer encouragement rather than a mentor. Two encouraging staff development people who I took classes from---.

y Several local administrators support and encourage me in my administrative endeavors.

y Ex-boss.

y I've had the pleasure of a supervisor who has encouraged and mentored me toward administration.

y I worked closely with, respected and admired a vice principal I worked with last year. 
WRITTEN RESPONSES - PROTEGES

y Supportive principals, assistant superintendent, personnel director, and staff development director have all been supportive and encouraging.

Question 46: Why do you think you vere selected for the
program?

My desire to learn and grow.

Administration was where I was headed and I had several people in a position that was helpful.

I feel that I was selected for this program because of my expressed interest, background experience, and coursework.

I think I was selected for several reasons. (1) My letter of application was persuasive and my background and qualifications made the committee feel I could be a potential administrator. (2) I was persistent. I was not accepted the first time I applied, so I reapplied. I also called Kate Dickson and asked for feedback on my rejection the first year. She told me that she was impressed by my pro-active approach. Perhaps that helped, too.

I had strong recommendations of people within my district who were involved in COSA.

My letter of application!

I had a range of educational experiences and had already obtained an MAT and basic administrative certificate.

Geographic concerns and good application.

Energy, recommendations, experiences.

Because I was seeking help in the development of my administrative skills and made it known that I had an interest in participating in the program. Also, I was the only person from Eastern Oregon.

I feel I was selected for the mentor program because of my experiences in staff Development and at that time position as Administrative Assistant. I was eager and enthusiastic about broadening my experiences.

I was a female. 
WRITTEN RESPONSES - DROTEGES

Second year I had applied and I believe they felt sorry for me. No, the match was excellent and I hope it's because they felt my mentor could challenge me and provide guidance which he did.

I am seriously committed to obtaining an administrative position. I feel both my principal and program advisor recommended me and believe I have potential.

I don't know. Perhaps my desire to be a principal was evident along with my desire to learn and stretch myself.

Because I was persistent in applying to the program for 3 years before being accepted.

-had commitment of time, interest, caring many years previous to application. -networking in state through NWEA and COSA prior to application.

-wrote a dynamite application.

I was qualified. I obtained an administrative certificate. I had a lot of potential.

I had completed course work at Lewis \& clark college and was serving on TSPC. I had also gone through COSA assessment center. So I had gone through the "hoops."

Lived in NE Oregon.

Written application and support from principal and mentor.

I suppose my letter indicated sincere interest and planning that would lead me to administration.

My career goals were very clear and evidently my letter was articulate.

Letter of application.

I am an excellent trainable candidate for a leadership role. This experience was unfortunate.

My past experience, work towards an administrative position plus my ability to write about my aspirations in education.

Do not know. 
WRITTEN RESPONSES - PROTEGES

I applied, was female, and it was the first year. Maybe I write well or they could see the tears on the application.

Aspirations.

Interest in program, potential, recommendations of district administrators.

My desire to work in a mentor/protege relationship, outside of my district, as I aspired to become an administrator.

Match with available mentor desire to be a protege.

I was recommended by our superintendent.

My first name is usually a female name and I believe there was an effort to include more women in administration.

Ethnicity, participation in Lewis \& Clark's ed administration program, Boyd Applegarth's support of program in first year.

Because of my desire to become an administrator and my persistence in communicating this to the district.

My qualifications and my employment in PPS.

I wrote a very detailed, succinct letter of application.

My sincerity in pursuing an administrative position.

I was and am serving in leadership positions at the building, district and county level. I hold an administrative certificate and am interested in a career change.

I was never told any specific reason for my selection. I believe I was one of the few who worked with special education administration. My background in both special education and regular education may have helped.

Work and educational background.

I had jumped through cosA's hoops (Assessment Center, Leadership Institute). I had a Masters, was enrolled in an administrative program and held a Basic certificate, had taught graduate programs, and developed curriculum. I had also written and received grants. 


\section{WRITTEN RESPONSES - RROTEGES}

I think I was selected because I had the qualifications, had membership in COSA, worked in NWEA, and was close to moving into administration. The selection committee I assume felt the mentorship could make that difference for me.

As a music teacher, I am quite "specialized" in one subject area. In my application, I explained what I had done to broaden my curricular background to better prepare me as a principal. I explained that I was working towards a Superintendent's certificate to open more doors for employability. My sincere desire to become an administrator was shown.

Applied, strong recommendations from Lewis \& Clark people. Because I am a female with a broad range of experiences and interests.

Just previous to being accepted into the mentorship program, I participated in the COSA Assessment Center program. I had a very positive experience and a strong, supportive report.

I believe that I possess the necessary abilities and skills to be a successful administrator. I feel that $I$ would be a positive, energizing force within a school structure, strong ability to help staff, parents and especially students dream the possible, strive for new risks, and celebrate successes on the road to a "great school."

Letter to committee. 
APPENDIX D

ADDITIONAL COMMENTS FROM QUESTIONNAIRE:

MENTORS 


\section{Additional comments--Hentors}

Additional:

My first experience was much more satisfactory than the second. Protege \#1 obviously was destined to be an administrator. (She became one the year after our Mentorship Year.) I saw helping her as a personal challenge; I knew she would be excellent and facilitated interviews, meeting the "right" people, etc. Protege $\$ 2$ had a low self-concept and was not the potential administrator that $\$ 1$ was. Although, \#2 could do it if she tries. I didn't work as hard the second time because I didn't see the same potential. Also, \#I and I have become personal friends. We had dinner together last month. My husband (also a principal) also helped \#1 because we both like and respect her. Probably, it was luck that made the first "pairing" work so well--we hit it off as friends. She's extremely bright, ambitious and able-she still calls to discuss problems of an elementary principal (which we both are).

Additional:

\#39 is a poorly written question--I taught 3rd grade for 5 years, 4 th grade for 2 years, LD at 1-6 for 2 years, Principal at $k-6$ for 6 years, and $7-9$ for 5 years. I didn't know how to indicate this with the $K-$ $3,4-6,7-9,10-12$ configuration. Sorry.

Additional:

$A$ benefit to me as a mentor was the experience of thinking through and verbalizing what and why I work as I do. Feedback from the protege was also useful.

Additional:

Mentoring an aspiring administrator is a very rewarding position albeit time consuming. We all have a responsibility to see that the next generation of administrators are qualified and committed to educational excellence and change.

Additional:

This program resulted in a lasting friendship and professional relationship between me (at in ) and my protege, became principal at mentorship year. following her who 


\section{Additional Comments--Mentors}

Additional:

I had relied on my protege to take the lead in our meetings. Her priorities changed as the year went on. She was not as interested in networking and moving on to another district as she was when she joined the program. So we did not get together and the value of the program faded for us both.

\section{Additional:}

I would like to recommend that mentors/proteges live/work no more than 15-20 miles apart to allow them to get together more often. It would be best if protege could spend 1-2 weeks (at least 1/2 days) with the mentor.

Additional:

Working with my protege, was a great experience. I felt we developed an excellent rapport and I probably learned as much from her as she learned from me. I got far more out of the program than I expected going into it. I believe our professional friendship will continue. In fact, I plan to call her tonight about a job vacancy she might in interested in!

\section{Additional:}

our location in southern Oregon made it difficult to attend evening sessions. The one we did attend was most valuable because of the 7 hours spent driving to and from Eugene.

\section{Additional:}

I am supportive of mentorings - a concept and practice. I benefitted from a couple of stellar people who extended to me. They were chemistry matches and successful. My protege and I never did hit the chemistry. I felt a sense of failure in that regard. It just became "work."

Additional:

Administration experience should be required for those selected as superintendent protege.

Additional:

Unfortunately, my protege had serious medical problems including surgery and was unable to complete the year as we had planned. From the outset we were both discouraged by her district's unwillingness to provide release time to pursue her efforts. 


\section{Additional comments--Xentors}

\section{Additional:}

I was delighted when my protege that first year was the first person to achieve her goal--the principalship.

Aditional:

This was an unusual situation for me, one that was confusing for me and really still is: What was my responsibility, as an individual, a mentor, a professional? My protege needed help with focusing her interests, aspirations, plans, that I knew. I began to have concerns about emotional stability and perspectives on and skills with administration. Mostly, I worked to help her think deeply, concentrate efforts. Only later did I learn how serious her personal issues were and that she was regarded as a very difficult, troubled employee. clearly this raises issues about protege selection and mentor responsibilities.

Additional:

As I have indicated throughout the concept is fine. The problem is the content. The dinners were without substance. I am social and enjoy visiting and dinner out, but speakers on educational trends, school issues, leadership styles, school reformation, etc. could have enriched the evening and been a topic of conversation during informal meetings. Expectations and standards should be clearer. The plan is too person specific to say success lies with the program. The people make it so.

\section{Additional :}

Unfortunately, I was matched with someone who had very little time and energy for this program. I was unable to make a positive reference at the conclusions of the project. 


\section{APPENDIX E}

ADDITIONAL COMLENTS FROM QUESTIONNAIRE:

PROTEGES 


\section{Additional Comments - Proteges}

Additional:

I think a stronger expectation of "shadowing" would be positive.

Additional:

I realize my comments about the program have been largely negative, but I feel the program itself has the potential to be of great value. I was very badly matched with my mentor and $I$ was so thankful to be in the program that it is only in looking back that $I$ realize I really should have done something to correct the problem. Instead, I just kept trying to fix the relationship; think of things we had in common, avoid subjects my mentor wasn't interested in, gloss over serious problems. There should be some criteria beyond geography for matching mentors with proteges. Furthermore, there should be a way to correct mismatches. Instead of the experience I expected, and that I feel most proteges had, I felt devalued by my mentor. Because there is not a second chance, an important opportunity was lost to me. Please correct this problem in what I still believe is an excellent program.

\section{Additional:}

Your survey should show that a majority of the people participating in the program do in fact become administrators. It would appear to me that southern and Eastern Oregon participants are greatly outnumbered by Eugene North and Gresham West people.

Secondly, small school participants would appear to be low. These two areas could be developed into programs of their own.

Additional:

I felt the program was valuable in that I met administrators around the state, giving me opportunities to discuss issues in the field. My personal experience with my mentor was not as valuable as I had hoped. Distance was a factor but more than that, I had a difficult time getting my mentor to share and discuss the challenges of an administrator. I had to keep "pulling" to get information. I felt more in the way when $I$ would visit his school, than welcomed. Although my experience wasn't as positive as I'd hoped, the overall program is worthwhile.

Additional :

This program was a formal manifestation of an informal system I had tried to build for myself. I'm glad that 


\section{Additional Comments - Proteges}

the women and minorities who come after me will have a road already partially paved. I am committed to returning the bucket full; I look forward to times when I can mentor others--some who are aware of what is possible for them and others who need some light provided.

Additional:

I was displeased with my mentor. I had to initiate all activities. I had to do all the calling. If I hadn't made all of the contacts I would have never heard from my mentor. When I went to visit him at his school, he turned me over to the VPs. He never really had time for me and I felt it.

\section{Additional:}

The relationship that was built with my mentor is still an ongoing relationship. I would like the opportunity to serve as a mentor in the future. It is helpful to develop a mentor and a perspective outside your district.

Additional:

Please consider this my own personal concern. I believe that the pairing of the mentor and protege should be the most important element in the project. without compatibility the poor protege is doomed to failure.

Additional:

As you can probably tell, my experience was not real successful (positive) . . but, the program has a great deal of value and merit. I hope that it continues with every year bring growth and improvements. The "mentor/protege" concept is very valuable to new teachers coming into the profession. That is--each new teacher (protege) should be assigned another teacher (mentor) for help, information, and support!

\section{Additional:}

Really depends on person you get. I was very lucky. We hit it off and decided to do our own thing. Liked it the first year, the lack of real structure but it was very difficult if you did not have a good match. Had a great time driving to dinner meetings. Meetings were a trial. Hearing stuff others did was a riot. 
Additional:

I think that the program was extremely beneficial for many, it just depended upon the match. I wish I had been clearer about my expectations going into the program so that I could have gotten more from it.

Additional:

I was fairly lucky. Many people never appeared after the first meeting. My mentor was supportive. only one person that $I$ know of was given an administrative job. It was an opportunity to share a time with others with like dreams. The speakers at the dinners were NOT good. I felt as if presentations were tossed together. COSA has a hard job--arranging these marriages. NWEA did nothing. I never even received an invitation to a meeting.

Additional:

I'm still striving to be an administrator. My district continues to be supportive and utilizes me as a substitute administrator when the building principal is absent. It is frustrating to believe in your abilities and not have the opportunity to "perform" as an administrator. I have found not only does discrimination exist on a male-female gender basis but on experience. I have been told although I have 13 years of elementary experience, I screened [out] because it is not direct "classroom" experience. I continue to develop my skills, broaden my curriculum background and apply as the school district that places their trust in my abilities will not be disappointed.

Additional:

This is my second year as a protege. The first time, my mentor was so negligent about the program, I was able to repeat in the program. This year, it's fine. 


\section{Additional comments - Proteges}

Additional:

My disappointment in the project mainly centered around the match with my mentor. Well into the program, I began to realize that my mentor didn't have much to share with me. I suppose because of the size of my ristrict in comparison, my current position provided me with many of the experiences my mentor had. I found myself, at times, mentoring my mentor in areas I had more experience in (administrative organization and policy and procedures). It would have been very awkward to switch mentors in that the likelihood of our continued contact in the field would be great. The risk of a strained relationship wasn't worth the possible result. 